Федеральная служба по надзору в сфере защиты прав потребителей и благополучия человека (Роспотребнадзор)

Федеральное бюджетное учреждение науки «Федеральный научный центр медико-профилактических технологий управления рисками здоровью населения»

\section{Адрес редакции:}

614045, Россия, Пермский край, г. Пермь, ул. Монастырская, 82

Тел.: 8 (342) 237-25-34

E-mail: journal@fcrisk.ru

Сайт: http://fcrisk.ru/journal/

Редактор и корректор - М.Н. Афанасьева Технический редактор - Е.Н. Несевря Переводчик - ООО «Линкс Динамикс»

Все права защищены. Ни одна часть этого издания не может быть занесена в память компьютера либо воспроизведена любым способом без предварительного письменного разрешения издателя.

Подписано в печать 30.09.2015.

Формат $90 \times 60 / 8$.

Усл. печ. л. 10,4.

Заказ № 185/2015.

Тираж 500 экз.

Журнал зарегистрирован

Федеральной службой по надзору

в сфере связи, информационных

технологий и массовых коммуникаций

Свидетельство о регистрации средства массовой информации ПИ № ФС 77-52552 от 21.01.2013

Журнал включен в базу данных Ulrich's Periodicals Directory и

Российский индекс научного цитирования (РИНЦ)

Адрес издательства и типографии: 614990, Пермь, Комсомольский пр., 29, к. 113, тел. 2-198-033

Отпечатано в Издательстве Пермского национального исследовательского политехнического университета (614990, Пермь, Комсомольский пр., 29, к. 113, тел. 2-198-033)

Журнал распространяется по подписке

Подписной индекс журнала по каталогу «Межрегионального агентства подписки» «Почта России» 04153

ISSN 2308-1155

\section{АНАЛИЗ РИСКА ЗДОРОВЬЮ}

Научно-практический журнал. Основан в 2013 г.

Bыходит 4 раза в год

\section{РЕДАКЦИОННАЯ КОЛЛЕГИЯ}

Г.Г. Онищенко - главный редактор, акад. РАН, д.м.н., проф. (г. Москва)

Н.В. Зайцева - заместитель главного редактора, акад. РАН, д.м.н., проф. (г. Пермь)

И.В. Май - ответственный секретарь, д.б.н., проф. (г. Пермь)

\section{РЕДАКЦИОННЫЙ СОВЕТ}

С.Л. Авалиани - д.м.н., проф. (г. Москва)

А.Б. Бакиров - акад. АН РБ, д.м.н., проф. (г. Уфа)

Е.Н. Беляев - чл.-корр. РАН, д.м.н., проф. (г. Москва)

В.М. Боев - д.м.Н., проф. (г. Оренбург)

И.В. Брагина - д.м.н. (г. Москва)

Р.В. Бузинов - к.м.н. (г. Архангельск)

И.В. Бухтияров - Д.М.Н., проф. (г. Москва)

А.И. Верещагин - к.м.н. (г. Москва)

В.Б. Гурвич - д.м.н. (г. Екатеринбург)

И. Дардынская - д.м.н., проф. (г. Чикаго, США)

М.А. Землянова - д.м.н. (г. Пермь)

Н.Ф. Измеров - акад. РАН, д.м.Н., проф. (г. Москва)

У.И. Кенесариев - д.м.н., проф., чл.-корр. АМН Казахстана

(г. Алматы, Казахстан)

Т. Кронберг - д.э.н., д.т.н. (г. Руваслахти, Финляндия)

С.В. Кузьмин - д.м.н., проф. (г. Екатеринбург)

В.В. Кутырев - акад. РАН, д.м.н., проф. (г. Саратов)

В.Р. Кучма - чл.-корр. РАН, д.м.н., проф. (г. Москва)

А.В. Мельцер - д.м.н., проф. (г. Санкт-Петербург)

А.Я. Перевалов - д.м.н., проф. (г. Пермь)

Ю.П. Пивоваров - акад. РАН, д.м.н., проф. (г. Москва)

А.Ю. Попова - Д.м.н., проф. (г. Москва)

В.Н. Ракитский - акад. РАН, д.м.Н., проф. (г. Москва)

С.И. Савельев - д.м.н., проф. (г. Липецк)

В.Ф. Спирин - д.м.н., проф. (г. Саратов)

В.А. Тутельян - акад. РАН, д.м.н., проф. (г. Москва)

Х.Х. Хамидулина - д.м.н., проф. (г. Москва)

В.А. Хорошавин - д.м.н. (г. Пермь)

С.А. Хотимченко - д.м.н., проф. (г. Москва)

Л.М. Шевчук - к.м.н. (г. Минск, Белоруссия)

Н.В. Шестопалов - д.м.н., проф. (г. Москва)

П.3. Шур - д.м.н. (г. Пермь)

\section{3(11)}

Июль 2015 Сентябрь 
ПРОФИЛАКТИЧЕСКАЯ МЕДИЦИНА: АКТУАЛЬНЫЕ АСПЕКТЫ АНАЛИЗА РИСКА ЗДОРОВЬЮ

А.Ю. Попова, Н.В.Зайцевва, И.В. Май, П.З. Шур К ПРОБЛЕМЕ ВЫБОРА ПРИОРИТЕТОВ ПРИ ОРГАНИЗАЦИИ РИСК-ОРИЕНТИРОВАННОГО

НАДЗОРА ЗА БЕЗОПАСНОСТЬЮ ПОТРЕБИ-

ТЕЛЬСКОЙ ПРОДУКЦИИ, ОБРАЩАЕМОЙ НА ЕДИНОМ ЭКОНОМИЧЕСКОМ ПРОСТРАН-

СТВЕ РОССИИ, РЕСПУБЛИКИ БЕЛАРУСЬ И РЕСПУБЛИКИ КАЗАХСТАН

\section{ПРАВОВЫЕ АСПЕКТЫ ОЦЕНКИ РИСКА}

E.B. Федоренко

ПРАВОВЫЕ ОСНОВЫ ПРИМЕНЕНИЯ

МЕТОДОЛОГИИ АНАЛИЗА РИСКА ПРИ ОБЕСПЕЧЕНИИ БЕЗОПАСНОСТИ ПИЩЕВОЙ ПРОДУКЦИИ В ЕВРАЗИЙСКОМ ЭКОНОМИЧЕСКОМ СОЮЗЕ И РЕСПУБЛИКЕ БЕЛАРУСЬ

\section{НАУЧНО-МЕТОДИЧЕСКИЕ ПОДХОДЫ К АНАЛИЗУ РИСКА В ГИГИЕНЕ И ЭПИДЕМИОЛОГИИ}

Н.А. Лебедева-Несевря, М.Ю. Цинкер МЕТОДИЧЕСКИЕ ПОДХОДЫ И ПРАКТИКА ОЦЕНКИ РИСКА, СВЯЗАННОГО С ВОЗДЕЙСТ-

ВИЕМ СОЦИАЛЬНО-ЭКОНОМИЧЕСКИХ ФАКТОРОВ НА ПОПУЛЯЦИОННОЕ ЗДОРОВЬЕ В РЕГИОНАХ РОССИИ

ПРАКТИКА ОЦЕНКИ РИСКА В ГИГИЕНИЧЕСКИХ И ЭПИДЕМИОЛОГИЧЕСКИХ ИССЛЕДОВАНИЯХ

Р.В. Бузинов, Е.А. Аверина, Т.Н. Унгуряну ВЛИЯНИЕ УСЛОВИЙ ОБРАЗОВАТЕЛЬНОЙ СРЕДЫ НА СОСТОЯНИЕ ЗДОРОВЬЯ ДЕТЕЙ ДОШКОЛЬНОГО И ШКОЛЬНОГО ВОЗРАСТА НА ТЕРРИТОРИИ АРХАНГЕЛЬСКОЙ ОБЛАСТИ

Ю.В. Корочкина, М.В. Перекусихин, В.В. Васильев, Г.В. Пантелеев ГИГИЕНИЧЕСКАЯ ОЦЕНКА ОКРУЖАЮЩЕЙ СРЕДЫ И ЗДОРОВЬЯ ДЕТЕЙ ГОРОДА ПЕНЗЫ

Л.М. Шевчук, Н.А. Толкачёва, А.Е. Пшегрода, И.П. Семёнов ГИГИЕНИЧЕСКАЯ ОЦЕНКА ВЛИЯНИЯ НА ЗДОРОВЬЕ НАСЕЛЕНИЯ ЗАГРЯЗНЕНИЯ АТМОСФЕРНОГО ВОЗДУХА С УЧЕТОМ КОМБИНИРОВАННОГО ДЕЙСТВИЯ ХИМИЧЕСКИХ ВЕЩЕСТВ В ЗОНЕ РАСПОЛОЖЕНИЯ ПРЕДПРИЯТИЯ ХИМИЧЕСКОЙ ПРОМЫШЛЕННОСТИ

\section{PREVENTIVE MEDICINE: URGENT ASPECTS OF RISK ANALYSIS}

4 A.Yu. Popova, N.V.Zaitseva, I.V. May, P.Z. Shur ON THE ISSUE OF SETTING PRIORITIES IN THE ORGANIZATION OF RISK-BASED SUPERVISION OVER THE SAFETY OF CONSUMER PRODUCTS TRADED ON THE COMMON ECONOMIC SPACE OF RUSSIA, BELARUS AND KAZAKHSTAN

\section{LEGAL ASPECTS OF RISK ASSESSMENT}

13 E.V. Fedorenko LEGAL BASIS FOR RISK ANALYSIS METHODOLOGY WHILE ENSURING FOOD SAFETY IN THE EURASIAN ECONOMIC UNION AND THE REPUBLIC OF BELARUS

\section{SCIENTIFIC AND METHODICAL APPROACHES TO RISK ANALYSIS IN HYGIENE AND EPIDEMIOLOGY}

19 N.A. Lebedeva-Nesevrya, M.Yu. Tsinker METHODICAL APPROACHES AND PRACTICE OF THE ASSESSMENT OF RISK ASSOCIATED WITH IMPACT OF SOCIAL AND ECONOMIC FACTORS ON THE POPULATION HEALTH IN THE REGIONS OF RUSSIA

\section{RISK ASSESSMENT PRACTICE IN HYGIENIC AND EPIDEMIOLOGICAL STUDIES}

27 R.V. Buzinov, E.A. Averina, T.N. Unguryanu EFFECT OF THE EDUCATIONAL

ENVIRONMENT ON CHILDREN'S HEALTH AT PRESCHOOL AND SCHOOL AGE IN THE ARKHANGELSK REGION

33 Yu.V. Korochkina, M.V. Perekusikhin, V.V. Vasilyev, G.V. Panteleev HYGIENIC ENVIRONMENTAL ASSESSMENT AND HEALTH OF CHILDREN IN PENZA

40 L.M. Shevchuk, N.A. Tolkacheva, A.E. Pshegroda, I.P. Semenov HYGIENIC ASSESSMENT OF IMPACT ON PUBLIC HEALTH AIR POLLUTION IN VIEW OF THE COMBINED ACTIONS OF CHEMICALS IN THE AREA OF THE CHEMICAL INDUSTRY 
ОЦЕНКА И УПРАВЛЕНИЕ РИСКАМИ В МЕДИЦИНЕ ТРУДА

Г.А. Безрукова, Т.А. Новикова, М.Л. Шалашова, С.С. Райкин ПРОФЕССИОНАЛЬНЫЙ РИСК РАЗВИТИЯ ЗАБОЛЕВАНИЙ ПЕРИФЕРИЧЕСКОЙ НЕРВНОЙ СИСТЕМЫ У ТРАКТОРИСТОВМАШИНИСТОВ СЕЛЬСКОХОЗЯЙСТВЕННОГО ПРОИЗВОДСТВА

С.С. Райкин, Т.А. Новикова ОЦЕНКА ФУНКЦИОНАЛЬНОГО СОСТОЯНИЯ И АДАПТАЦИОННЫХ РЕЗЕРВОВ МЕХАНИЗАТОРОВ СЕЛЬСКОГО ХОЗЯЙСТВА С РАЗЛИЧНЫМ СТАЖЕМ РАБОТЫ В ПРОФЕССИИ

\section{МЕДИКО-БИОЛОГИЧЕСКИЕ АСПЕКТЫ ОЦЕНКИ ВОЗДЕЙСТВИЯ ФАКТОРОВ РИСКА}

О.В. Долгих, А.В. Кривиов, К.Г. Старкова, В.А. Лучникова, О.А. Бубнова, Д.Г. Дианова, Н.В. Безрученко, Н.А. Вдовина СИСТЕМА МЕДИАТОРОВ ИММУННОЙ РЕГУЛЯЦИИ КАК МАРКЕРОВ ИММУНОЛОГИЧЕСКИХ НАРУШЕНИЙ У ШКОЛЬНИКОВ В УСЛОВИЯХ ПОВЫШЕННОГО ПОСТУПЛЕНИЯ СТРОНЦИЯ С ПИТЬЕВОЙ ВОДОЙ

ЭКСПЕРИМЕНТАЛЬНЫЕ МОДЕЛИ И ИНСТРУМЕНТАЛЬНЫЕ ИССЛЕДОВАНИЯ ДЛЯ ОЦЕНКИ РИСКА В ГИГИЕНЕ И ЭПИДЕМИОЛОГИИ

Д.А. Кирьянов, Д.В. Ланин, В.М. Чигвинщев МАТЕМАТИЧЕСКАЯ МОДЕЛЬ ФУНКЦИОНИРОВАНИЯ ИММУННОЙ И НЕЙРОЭНДОКРИННОЙ СИСТЕМ С УЧЕТОМ ЭВОЛЮЦИИ НАРУШЕНИЙ СИНТЕТИЧЕСКОЙ ФУНКЦИИ ОРГАНОВ

Н.Р. Ефимочкина, И.Б. Быкова, Ю.В. Короткевич, Ю.М. Маркова, Л.П. Минаева, С.А. Шевелева ИЗУЧЕНИЕ ТОЛЕРАНТНОСТИ ЭНТЕРОБАКТЕРИЙ К ХЛОРСОДЕРЖАЩИМ БИОЦИДНЫМ СРЕДСТВАМ В ЭКСПЕРИМЕНТАЛЬНЫХ МОДЕЛЯХ С ИСПОЛЬЗОВАНИЕМ ХРОМОГЕННЫХ ИНДИКАТОРНЫХ ТЕСТ-СИСТЕМ
HEALTH RISK MANAGEMENT

47 G.A. Bezrukova, T.A. Novikova, M.L. Shalashova, S.S. Raikin PROFESSIONAL RISK OF DEVELOPING DISEASES OF THE PERIPHERAL NERVOUS SYSTEM IN TRACTOR DRIVERS MACHINE OPERATORS OF AGRICULTURAL PRODUCTION

55 S.S. Raikin, T.A. Novikova ASSESSMENT OF FUNCTIONAL STATE AND ADAPTATION RESERVES OF MACHINE OPERATORS IN AGRICULTURE WITH DIFFERENT WORK EXPERIENCE IN THE PROFESSION

\section{MEDICAL AND BIOLOGICAL ASPECTS OF THE ASSESSMENT OF THE RISK FACTORS}

61 O.V. Dolgikh, A.V. Krivtsov, K.G. Starkova, V.A. Luchnikova, O.A. Bubnova, D.G. Dianova, N.V. Bezruchenko, N.A. Vdovina NEUROTRANSMITTER SYSTEM OF IMMUNE REGULATION AS A MARKER OF IMMUNOLOGICAL DISORDERS IN PUPILS IN THE CONDITIONS OF INCREASED ENTRY OF STRONTIUM WITH DRINKING WATER

\section{EXPERIMENTAL MODEL AND \\ MEASUREMENT STUDIES OF RISK ASSESSMENT IN HYGIENE AND EPIDEMIOLOGY}

68 D.A. Kiryanov, D.V. Lanin, V.M. Chigvintsev MATHEMATICAL MODEL OF IMMUNE AND NEUROENDOCRINE SYSTEMS FUNCTIONING WITH REGARD TO EVOLUTION OF ORGAN SYNTHETIC FUNCTION VIOLATIONS

73 N.R. Efimochkina, I.B. Bykova, Yu.V. Korotkevich, Yu.M. Markova, L.P. Minaeva, S.A. Sheveleva STUDY OF TOLERANCE OF ENTEROBACTERIA TO CHLORINE-BASED BIOCIDES IN EXPERIMENTAL MODELS USING CHROMOGENIC INDICATOR TESTS 
УДК 614.3

\author{
К ПРОБЛЕМЕ ВЫБОРА ПРИОРИТЕТОВ ПРИ ОРГАНИЗАЦИИ \\ РИСК-ОРИЕНТИРОВАННОГО НАДЗОРА ЗА БЕЗОПАСНОСТЬЮ \\ ПОТРЕБИТЕЛЬСКОЙ ПРОДУКЦИИ, ОБРАЩАЕМОЙ \\ НА ЕДИНОМ ЭКОНОМИЧЕСКОМ ПРОСТРАНСТВЕ РОССИИ, \\ РЕСПУБЛИКИ БЕЛАРУСЬ И РЕСПУБЛИКИ КАЗАХСТАН
}

\author{
А.Ю. Попова ${ }^{1}$ Н.В.Зайцева ${ }^{2}$, И.В. Май르 П.З. Шур \\ ${ }^{1}$ Федеральная служба по надзору в сфере защиты прав потребителей и благополучия человека, \\ Россия, 127994, г. Москва, Вадковский переулок, 18, строение 5 и 7 \\ ${ }^{2}$ ФБУН «Федеральный научный центр медико-профилактических технологий управления \\ рисками здоровью населения», \\ Россия, 614045, г. Пермь, ул. Монастырская, 82
}

Значительные объемы взаимной торговли между странами Евразийского экономического союза в сочетании с актуальностью защиты населения от рисков негативных воздействий продукции на здоровье ставят задачу оптимизачии надзора за продукцией, обращаемой на рынке. Одним из путей оптимизачии является переход на рискориентированную модель деятельности санитарной службы и выбор видов продукиии, подлежащих первоочередному (приоритетному) контролю. Предложены подходы к выбору приоритетов, основанные на учете масштабов использования продукции, специфики контингентов потребителей, известных видов опасностей, результатов контрольно-надзорной деятельности. Установлено, что к приоритетным видам продукиии, экспортируемой странами-членами ЕАЭС на общий рынок и формирующим потенщиально наибольшие риски причинения вреда здоровью потребителей могут быть отнесены: молочная продукция; яйца птии (группа ТН ВЭД 04); жиры и масла животного или растительного происхождения и продукты их расщепления; готовые пищевые жиры; воски животного или растительного происхождения (группа ТН ВЭД 15); сахар и кондитерские изделия из сахара (группа ТН ВЭД 17); продукты из мяса, рыбы или ракообразных, моллюсков или прочих водных беспозвоночных (группа ТН ВЭД 16); алкогольные и безалкогольные напитки и пр. (группа ТН ВЭД 22); овощчи, корнеплоды и клубнеплоды (группа ТН ВЭД 07); игрушки, игры и спортивный инвентарь (группа ТН ВЭД 95). В отношении данных групп товаров необходимым является первоочередное обоснование профилей риска, разработка алгоритмов и регламентов проведения контрольно-надзорных мероприятий и совершенствование методов их лабораторного сопровождения.

Ключевые слова: потребительские товары, безопасность, риск-ориентированный надзор.

Евразийский экономический союз на сегодня - это более 20 млн км ${ }^{2}$ территории, на которой проживает порядка 182,1 млн человек. Годовой объем взаимной торговли ЕАЭС превышает 60 млрд долларов CША (USD). В этой сумме более 14 млрд долларов составляют объемы взаимной торговли потребительскими товарами: 7,5 млрд долларов - непродовольст- венными товарами; 6,6 млрд долларов - продовольственными товарами. При этом наиболее значимые вклады в объемы взаимной торговли вносят Российская Федерация, Республика Беларусь и Республика Казахстан. Население этих стран (в сумме более 173 млн человек) формирует и самый большой потребительский рынок [7].

(c) Попова А.Ю., Зайцева Н.В., Май И.В., Шур П.З., 2015

Попова Анна Юрьевна - доктор медицинских наук, профессор, руководитель, главный государственный санитарный врач Российской Федерации (e-mail: depart@gsen.ru; тел. 8 (499) 973-26-90).

Зайцева Нина Владимировна - академик РАН, доктор медицинских наук, профессор, директор (e-mail: znv@fcrisk.ru; тел. 8 (342) 237-25-34).

Май Ирина Владиславовна - доктор биологических наук, профессор, заместитель директора по научной работе (e-mail: may@fcrisk.ru; тел. 8 (342) 237-25-47).

Шур Павел Залманович - доктор медицинских наук, ученый секретарь (e-mail: shur@fcrisk.ru; тел. 8 (342) 238-33-37). 
Свободное движение товаров, как и свободное движение услуг, капитала и рабочей силы, являются условием существования и развития Евразийского экономического союза. Однако обращение на общем рынке большой массы и номенклатуры товаров широкого круга производителей из разных стран требует эффективных мер по обеспечению безопасности населения каждого государства в отдельности и союза в целом.

Защита граждан от некачественной и потенциально опасной для здоровья потребительской продукции на территории единого экономического пространства, в том числе продукции, поступающей из государств-участниц ЕАЭС, рассматривается Федеральной службой в сфере защиты прав потребителей и благополучия человека Российской Федерации как важнейшее направление деятельности. Санитарные службы используют весь набор законодательно закрепленных инструментов контроля и надзора - это и надзор за производством пищевых продуктов (в том числе за применением принципов ХАССП), и лицензирование определенных видов деятельности, в том числе связанных с производством потребительских товаров, и регистрация впервые внедряемых в производство и ранее не использовавшихся химических, биологических веществ и препаратов, отдельных видов опасной продукции и ряда товаров, впервые ввозимых на территорию Российской Федерации.

Вместе с тем отдельной задачей остается контроль безопасности продукции, уже выпущенной на рынок и претерпевшей ряд транспортировок, упаковок, перегрузок или иных операций на пути от производителя к потребителю. Государственный санитарный надзор должен ставить и ставит надежный барьер на пути потенциально опасных товаров к потребителю. Так, Управлениями Роспотребнадзора по субъектам Российской Федерации в установленном законом порядке только в 2014 г. было изъято товаров из оборота в натуральном выражении 101623,2 единицы, что составило $3,0 \%$ от общего количества проверенных товаров. Среди изъятых из оборота товаров - мясо и птица (порядка 72 тонн, или 1,8\% проинспектированной продукции); колбасные изделия (более 19 тонн, или 0,7\% проинспектированной продукции), цельномолочная продукция (более 44 тонн, или 3,4\%), детское молочное сухое питание (77,4 тонны, или $0,8 \%$ проинспектированной продукции) и т.п. [4].

В Республике Беларусь в 2014 г. органами санитарного надзора выявлено, что из 113,45 тысячи проб пищевых продуктов и продовольственного сырья порядка 0,56 \% проб не отвечали гигиеническим нормативам содержания химических загрязнителей; порядка 1,7\% плодоовощной продукции не удовлетворяло требованиям по микробиологическим показателям, что создавало угрозу для жизни и здоровья потребителей. Приняты меры по удалению товаров из обращения [6].

Органы надзора в Республике Казахстан, контролируя и демпфируя риски для здоровья населения, в первом полугодии 2013 г. выявили и забраковали порядка 100 тонн недоброкачественных продуктов питания (молочная продукция - 43 тонны, мясная продукция 14 тонн, кондитерские изделия - 10 тонн), которые не соответствовали санитарным нормам по микробиологическим показателям и/или не имели документов, подтверждающих соответствие обязательным санитарно-эпидемиологическим требованиям [2].

Вместе с тем вести тотальный контроль безопасности потребительских товаров в условиях значительного и распределенного рынка крайне сложно. Ситуация усугубляется существенным расширением параметров, которые требуется исследовать, при оценке безопасности товара [1, 9-11]. Адекватные установленным нормам безопасности современные лабораторно-инструментальные исследования, сопровождающие контрольно-надзорные мероприятия, существенно удорожают процедуру контроля и должны использоваться исключительно целенаправленно и результативно. Таким образом, встает проблема обоснованного выбора приоритетов при организации контроля (надзора). Прежде всего это касается четкого выделения товаров, формирующих наибольшие риски для здоровья потребителей. Задача актуальна как для Российской Федерации, так и для других стран-членов Евразийского экономического союза.

Следует отметить, что в Республике Беларусь перечень продукции, представляющей потенциальную опасность для жизни и здоровья населения, законодательно закреплен [8]. Согласно Постановлению Минздрава Республики Беларусь к такой продукции относятся:

- минеральная вода (природная столовая, лечебно-столовая, лечебная), бутилированная питьевая вода, расфасованная в емкости (в том числе для использования в детском питании);

- тонизирующие напитки;

- алкогольная продукция, слабоалкогольная продукция, пиво; 
- специализированные пищевые продукты, в том числе продукты: детского питания, предназначенные для беременных и кормящих женщин, а также для диетического и спортивного питания;

- биологически активные добавки к пище, сырье для производства биологически активных добавок к пище;

- пищевые продукты, полученные с использованием генно-инженерно-модифицированных (трансгенных) организмов,

- пищевые добавки, ароматизаторы, растительные экстракты и т.П.;

- стартовые культуры микроорганизмов и бактериальные закваски, технологические вспомогательные средства, в том числе ферментные препараты;

- косметическая продукция; средства и изделия для гигиены полости рта;

- средства дезинфекции, дезинсекции и дератизации;

- товары бытовой химии;

- предметы личной гигиены для детей и взрослых;

- предметы детского обихода до трех лет: посуда и изделия, используемые для питания детей, предметы по гигиеническому уходу;

- одежда для детей (первый слой);

- изделия, предназначенные для контакта с пищевыми продуктами (кроме столовых принадлежностей, технологического оборудования;

- ряд других товаров.

Утвержденный документом список товаров довольно обширен. Реализация контроля по всему перечню продукции крайне затруднительна, что требует дополнительных критериев приоритезации объектов надзора.

К потенциально опасным товарам в Российской Федерации ранее были отнесены материалы, оборудование, устройства и другие технические средства водоподготовки, предназначенные для использования в системах хозяйственно-питьевого водоснабжения; дезинфицирующие, дезинсекционные и дератизационные средства для применения в быту, в лечебнопрофилактических учреждениях и на других объектах для обеспечения безопасности и здоровья людей (кроме применяемых в ветеринарии); товары бытовой химии. Однако действовавшее до 2012 г. Постановление № 262 от 04.04.2001 г. [3] ныне отменено.

Список приоритетных товаров, подлежащих первоочередному контролю на стадии обращения товаров на рынке, в ЕАЭС на сегодня отсутствует.
В соответствии с товарной номенклатурой внешнеэкономической деятельности ЕАЭС (ТН ВЭД), определенной решением совета ЕЭК № 54 от 16.07.2012 г. [5], из 97 групп товаров отдельные товары из 69 групп подлежат санитарно-эпидемиологическому надзору на таможенной границе и территории ЕАЭС. Это - пищевые продукты (ТН ВЭД 02-05, 07 5, 27 9, 32-34, 35), товары для детей (ТН ВЭД 32, 34, 39, 40, 42-44, 46, 48-56, 60-65, 87, 94, 95), парфюмерно-косметические средства, средства гигиены (из группы ТН ВЭД 33) и др.

Переход на организацию контрольно-надзорных мероприятий с учетом потенциального риска причинения вреда здоровью потребителей, т.е. внедрение модели риск-ориентированного надзора, в полной мере соответствует интересам всех сторон: граждан как потребителей, органов власти, бизнеса. Концентрация усилий надзорных органов на объектах, представляющих наибольшую опасность для здоровья потребителей, повышает гарантии потребителей на безопасную продукцию и, одновременно, способствует более рациональному и эффективному использования средств, выделенных на осуществление надзора за исполнением государственной функции. Обеспечение условий адекватности интенсивности контрольно-надзорной деятельности риску причинения вреда, предполагающих сокращение числа проверок на объектах низкого риска для потребителей, способствует снижению общей административной нагрузки на бизнес. Прозрачность и ясность процедур оценки риска в целом повышает доверие общества к надзорным органам.

С целью внедрения модели риск-ориентированного надзора за безопасностью в потребительской продукции были предложены подходы для предварительного рекогносцировочного выбора приоритетов на территории единого экономического пространства ЕАЭС.

В качестве критериев выбора приоритетных видов товаров рассматривались частота вероятных нарушений обязательных требований к безопасности продукции, наличие среди потребителей товаров особо уязвимых групп детей, беременных, пожилых людей или людей с ограниченными возможностями, а также масштаб вероятных негативных последствий для здоровья населения.

При сборе исходных данных и их анализе руководствовались следующими положениями:

- продукция должна была быть внесена в «Единый перечень товаров, подлежащих санитарно-эпидемиологическому надзору (кон- 
тролю) на таможенной границе и таможенной территории Таможенного союза» и иметь код по ТН ВЭД Таможенного союза;

- для каждого вида продукции должны быть определены объемы (нормативы) потребления на 1 человека в год;

- единицы измерения количества продукции и объемов (нормативов) потребления должны совпадать;

- система оценок строится на открытой общедоступной информации о товарообороте и результатах предыдущей контрольно-надзорной деятельности.

Для определения приоритетных видов продукции проводили вычисление долевого вклада каждого вида продукции по формуле

$$
\omega_{i}=\left(\frac{\text { potr }_{i}}{\sum_{\text {potr }}}\right) 100,
$$

где $\omega_{i}$ - долевой вклад продукции в общее потребление товаров;

$$
\text { potr }_{i} \text { - число потребителей данного вида }
$$
продукции;

$\sum_{\text {potri }}$ - общее число населения, пользующихся товарами.

Число потребителей конкретного вида товаров определяли как отношение общей обращаемой массы продукции (объема, штук и пр.) к средней норме потребления этого товара.

Т аблиц а 1

Суммарный объем взаимных экспортных поставок ряда основных товаров,

\begin{tabular}{|c|c|c|c|c|}
\hline $\begin{array}{l}\text { Код ТН } \\
\text { ВЭД ТС }\end{array}$ & Продукция & $\begin{array}{c}\text { Единица } \\
\text { измерения }\end{array}$ & $\begin{array}{c}\text { Суммарный } \\
\text { объем экспорт- } \\
\text { ных поставок }\end{array}$ & $\begin{array}{c}\text { Усредненные годо- } \\
\text { вые нормы потребле- } \\
\text { ния на человека }\end{array}$ \\
\hline 1 & 2 & 3 & 4 & 5 \\
\hline 0401 & Молоко и сливки несгущенные & $\mathrm{T}$ & 296420 & \multirow{4}{*}{0,11} \\
\hline 0402 & Молоко и сливки сгущенные и сухие & $\mathrm{T}$ & 197757 & \\
\hline 0403 & Пахта, йогурт, кефир & $\mathrm{T}$ & 46030 & \\
\hline 0404 & Молочная сыворотка & $\mathrm{T}$ & 66968 & \\
\hline 0405 & Масло сливочное & $\mathrm{T}$ & 81996 & 0,004 \\
\hline 0406 & Сыры и творог & $\mathrm{T}$ & 141549 & 0,024 \\
\hline из 0407 & Яйца & тыс. шт. & 658950 & 0,260 \\
\hline 0702 & Томаты & $\mathrm{T}$ & 38995 & 0,12 \\
\hline 1512 & Масло подсолнечное & $\mathrm{T}$ & 116971 & 0,01 \\
\hline 1601 & Колбасы и аналогичные продукты из мяса & $\mathrm{T}$ & 103693 & 0,07 \\
\hline 1604 & Готовая или консервированная рыба. Икра & $\mathrm{T}$ & 24506 & 0,016 \\
\hline 1701 & Caxap & $\mathrm{T}$ & 302680 & 0,024 \\
\hline 1806 & $\begin{array}{l}\text { Шоколад и прочие готовые пищевые продукты, } \\
\text { содержащие какао }\end{array}$ & $\mathrm{T}$ & 72418 & 0,0146 \\
\hline 1905 & Хлеб и мучные кондитерские изделия & $\mathrm{T}$ & 69881 & 0,095 \\
\hline 2203 & Пиво & л & 143072753 & 182,5 \\
\hline 6202 & Верхняя одежда женская текстильная & ШТ. & 751596 & 0,4 \\
\hline 6203 & Одежда мужская текстильная & шт. & 1787361 & 1,9 \\
\hline 6204 & Одежда женская текстильная & ШТ. & 1714746 & 2,9 \\
\hline 6403 & Обувь с верхом из натуральной кожи & пар & 9147587 & 2 \\
\hline 8471 & $\begin{array}{l}\text { Вычислительные машины для автоматической } \\
\text { обработки информации }\end{array}$ & шт. & 4784690 & 1 \\
\hline 8517 & Аппаратура связи и части к ней & ШТ. & 4356804 & 1,5 \\
\hline из 2402 & Табачные изделия & тыс. шт. & 8664920 & 7,3 \\
\hline из 6115 & Чулочно-носочные изделия & шт. & 46479998 & 5 \\
\hline из 6212 & Корсетные изделия & Шт. & 12163206 & 3,75 \\
\hline из 8413 & Насосы жидкостные & Шт. & 2068341 & 1 \\
\hline из 8414 & $\begin{array}{l}\text { Насосы воздушные или вакуумные, компрессоры и } \\
\text { вентиляторы }\end{array}$ & шт. & 1202673 & 1 \\
\hline из 8418 & $\begin{array}{l}\text { Холодильники, морозильники и холодильное обо- } \\
\text { рудование }\end{array}$ & шт. & 1125152 & 1 \\
\hline из 8433 & $\begin{array}{l}\text { Машины и механизмы для уборки и обмолота } \\
\text { сельскохозяйственных культур }\end{array}$ & шт. & 189197 & 1 \\
\hline из 8516 & $\begin{array}{l}\text { Бытовые и прочие электронагревательные прибо- } \\
\text { ры, электроплиты }\end{array}$ & шт. & 1428210 & 1 \\
\hline из 9013 & Устройства на жидких кристаллах, лазеры & шт. & 28 & 1 \\
\hline
\end{tabular}

Российской Федерации, Республики Казахстан и Республики Беларусь (2012 г.) 
Подходы апробировали, используя в качестве исходных данных: статистическую информацию об объемах экспортных поставок основных товаров Российской Федерации, Республики Казахстан и Республики Беларусь в государства - члены Единого экономического пространства за 2012 г. и статистическую информацию о производстве продукции в натуральном выражении в 2012 г. Российской Федерацией, Республикой Казахстан и Республикой Беларусь (табл. 2). Пример исходных данных - в табл. 1.

Частоту нарушений санитарно-эпидемиологических требований, регистрируемых в отношении того или иного вида товара, принимали в соответствии с данными уполномоченных органов, отражающими результаты контрольно-надзорной деятельности (пример данных по Российской Федерации приведен в табл. 2).

Определено, что из товаров, экспортируемых Россией, Казахстаном и Белоруссией на общий рынок, наибольшее число жителей государств-стран ЕАЭС подвержено потенциаль- ному негативному влиянию в отношении пищевой продукции - товарам из группы «Молочная продукция» (группа ТН ВЭД 04) из группы «Жиры и масла животного или растительного происхождения и продукты их расщепления...» (группа ТН ВЭД 15) и из группы «Готовые продукты из мяса, рыбы или ракообразных, моллюсков или прочих водных беспозвоночных» (группа ТН ВЭД 16) - более 5 млн человек (табл. 3).

К приоритетной относили продукцию, доля потенциальных потребителей которой превышала $5 \%$ об общего числа населения, в отношении которой регистрировались случаи нарушения санитарно-гигиенических требований, и в число потребителей продукции входили уязвимые группы населения.

В целом с учетом масштабов распространения продукции, специфики контингентов потребителей, известных видов опасностей, результатов контрольно-надзорной деятельности последних лет к приоритетным видам продукции, экспортируемой странами-членами ЕАСЭ на общий рынок и формирующей потенциально

Таблица 2

Сведения о результатах проверок территориальных органов Роспотребнадзора в отношении отдельных видов товаров (продукции) (2012-2014 гг.) ${ }^{1}$

\begin{tabular}{|l|c|c|c|}
\hline \multirow{2}{*}{\multicolumn{1}{|c|}{ Наименование товара (товарной группы) }} & \multicolumn{3}{|c|}{ Доля продукции, не соответствующей санитарно- } \\
\cline { 2 - 4 } & эпидемиологическим требованиям и нормативам, \% \\
\hline Мясо и птица & $\mathbf{2 0 1 2}$ & $\mathbf{2 0 1 3}$ & $\mathbf{2 0 1 4}$ \\
\hline в том числе мясо птицы & 5,0 & 11,0 & 1,8 \\
\hline Изделия колбасные & 5,0 & 4,0 & 2,4 \\
\hline Консервы мясные и мясорастительные & 3,0 & 0,9 & 0,7 \\
\hline Консервы мясорастительные детские & 2,0 & 0,3 & 0,3 \\
\hline Продукция рыбная пищевая (без рыбных консервов) & 0,2 & 0,0 & 0,1 \\
\hline Консервы и пресервы из морепродуктов & 4,0 & 4,2 & 4,8 \\
\hline Масло животное & 1,0 & 1,1 & - \\
\hline Продукция майонезная и маргариновая & 2,0 & 1,3 & 1,8 \\
\hline Сыры & 1,0 & 0,7 & 2,0 \\
\hline Цельномолочная продукция & 1,0 & 1,6 & 1,8 \\
\hline Детское молочное сухое питание & 4,0 & 0,6 & 3,4 \\
\hline Яйцо птицы & 1,0 & 0,5 & 0,9 \\
\hline Изделия макаронные & 4,0 & 0,1 & 0,7 \\
\hline Сахар & 1,0 & 0,4 & 0,2 \\
\hline Кондитерские изделия & 1,0 & 0,2 & 0,7 \\
\hline Пряности пищевкусовые, приправы, добавки & 4,3 & 3,5 \\
\hline Безалкогольные напитки и минеральные воды & 6,0 & 5,7 & 7,0 \\
\hline Консервы плодоовощные и ягодные & 7,0 & 2,5 & 0,3 \\
\hline Консервы для детского, диетического и диабетического питания & 1,0 & 0,4 & 0,6 \\
\hline Средства моющие синтетические & 1,0 & 2,0 & 0,0 \\
\hline Изделия парфюмерно-косметические & 9,0 & 1,6 & 0,6 \\
\hline
\end{tabular}

\footnotetext{
${ }^{1}$ Форма федерального статистического наблюдения № 1-КЧ «Сведения о качестве проинспектированных потребительских товаров и нарушениях норм и правил торговли» / утв. Приказом Росстата № 38 от 4 июля 2005 г.
} 
К проблеме выбора приоритетов при организации риск-ориентированного надзора за безопасностью ...

Таблица 3

Число потребителей ряда товаров из объема экспортных поставок Российской Федерации, Республики Казахстан и Республики Беларусь в государства - члены ЕАЭС и Единого экономического пространства (2012 г.)

\begin{tabular}{|c|c|c|c|}
\hline Код ТН ВЭД ТС & Продукция & $\begin{array}{l}\text { Число } \\
\text { потенциальных } \\
\text { потребителей } \\
\text { продукции, чел. }\end{array}$ & $\begin{array}{c}\text { Доля, } \\
\%\end{array}$ \\
\hline 1 & 2 & 3 & 4 \\
\hline \multicolumn{2}{|c|}{$\begin{array}{l}\text { Группа 04. Молочная продукция; яйца птиц; мед натуральный; пищевые продукты } \\
\text { животного происхождения, в другом месте не поименованные или не включенные, } \\
\text { в том числе: }\end{array}$} & 39425750 & \multirow{8}{*}{22,75} \\
\hline 0406 & Сыры и творог & 5897875 & \\
\hline 0401 & Молоко и сливки несгущенные & \multirow{4}{*}{5519772} & \\
\hline 0402 & Молоко и сливки сгущенные и сухие & & \\
\hline 0403 & Пахта, йогурт, кефир & & \\
\hline 0404 & Молочная сыворотка & & \\
\hline 0405 & Масло сливочное & 20499000 & \\
\hline из 0407 & Яйца & 2534 & \\
\hline \multicolumn{2}{|c|}{ Группа 07. Овощи и некоторые съедобные корнеплоды и клубнеплоды } & 324958 & 0,23 \\
\hline \multicolumn{2}{|c|}{$\begin{array}{l}\text { Группа 15. Жиры и масла животного или растительного происхождения и продукты } \\
\text { их расщепления; готовые пищевые жиры; воски животного или растительного проис- } \\
\text { хождения }\end{array}$} & 14453220 & 8,34 \\
\hline \multicolumn{2}{|c|}{$\begin{array}{l}\text { Группа 16. Готовые продукты из мяса, рыбы или ракообразных, моллюсков или прочих } \\
\text { водных беспозвоночных, в том числе: }\end{array}$} & 4263180 & \multirow{4}{*}{2,46} \\
\hline 1601 & Колбасы и аналогичные продукты из мяса & \multirow{2}{*}{1915214} & \\
\hline 1602 & Готовые или консервированные продукты из мяса & & \\
\hline 1604 & Готовая или консервированная рыба, икра & 1531625 & \\
\hline \multicolumn{2}{|c|}{ Группа 17. Сахар и кондитерские изделия из сахара } & 15579675 & 8,99 \\
\hline \multicolumn{2}{|c|}{ Группа 18. Какао и продукты из него } & 4960136 & 3,54 \\
\hline \multicolumn{2}{|c|}{$\begin{array}{l}\text { Группа 19. Готовые продукты из зерна злаков, муки, крахмала или молока; мучные конди- } \\
\text { терские изделия }\end{array}$} & 735589 & 0,52 \\
\hline \multicolumn{2}{|c|}{ Группа 22. Алкогольные и безалкогольные напитки и уксус } & 783960 & 0,56 \\
\hline \multicolumn{2}{|c|}{ Группа 24. Табак и промышленные заменители табака } & 23739 & 0,02 \\
\hline \multicolumn{2}{|c|}{$\begin{array}{l}\text { Группа 61. Предметы одежды и принадлежности к одежде, трикотажные машинного или } \\
\text { ручного вязания }\end{array}$} & 11489790 & 6,63 \\
\hline \multicolumn{2}{|c|}{$\begin{array}{l}\text { Группа 62. Предметы одежды и принадлежности к одежде, кроме трикотажных машинного } \\
\text { или ручного вязания }\end{array}$} & 8491170 & 4,96 \\
\hline \multicolumn{2}{|c|}{ Группа 64. Обувь, гетры и аналогичные изделия; их детали } & 5649580 & 3,26 \\
\hline \multicolumn{2}{|c|}{$\begin{array}{l}\text { Группа 85. Электрические машины и оборудование, их части; звукозаписывающая и зву- } \\
\text { ковоспроизводящая аппаратура, аппаратура для записи и воспроизведения телевизионного } \\
\text { изображения и звука, их части и принадлежности }\end{array}$} & 8006760 & 4,62 \\
\hline \multicolumn{2}{|c|}{$\begin{array}{l}\text { Группа 94. Мебель; постельные принадлежности, матрацы, основы матрацные, диванные } \\
\text { подушки и аналогичные набивные принадлежности мебели; лампы и осветительное обо- } \\
\text { рудование, в другом месте не поименованные или не включенные; световые вывески, све- } \\
\text { товые, в том числе: }\end{array}$} & 4713760 & \multirow[t]{3}{*}{2,72} \\
\hline из 9403 & Мебель прочая и ее части & 2832262 & \\
\hline из 9401 & Мебель для сидения и ее части & 983245 & \\
\hline \multicolumn{2}{|c|}{ Группа 95. Игрушки, игры и спортивный инвентарь; их части и принадлежности } & 41037440 & 23,68 \\
\hline
\end{tabular}


наибольшую опасность для здоровья потребителей, могут быть отнесены:

- молочная продукция; яйца птиц (группа ТН ВЭД 04);

- жиры и масла животного или растительного происхождения и продукты их расщепления; готовые пищевые жиры; воски животного или растительного происхождения (группа ТН ВЭД 15);

- сахар и кондитерские изделия из сахара (группа ТН ВЭД 17);

- готовые продукты из мяса, рыбы или ракообразных, моллюсков или прочих водных беспозвоночных (группа ТН ВЭД 16);

- алкогольные и безалкогольные напитки и пр. (группа ТН ВЭД 22);

- овощи и некоторые съедобные корнеплоды и клубнеплоды (группа ТН ВЭД 07);

- игрушки, игры и спортивный инвентарь, их части и принадлежности (группа ТН ВЭД 95).
Перечень приоритетных видов товаров не является исчерпывающим и статичным. Сокращение или увеличение частоты нарушений санитарного законодательства и законодательства в сфере технического регулирования по той или иной продукции, изменение номенклатуры или объема товаров, поставляемых на общий рынок единого экономического пространства - все это может изменить структуру приоритетов. Однако на текущий момент именно в отношении выделенных групп товаров необходимым является первоочередное обоснование профилей риска, внедрение модели риск-ориентированного надзора, разработка алгоритмов и регламентов проведения контрольно-надзорных мероприятий с учетом потенциального риска причинения вреда здоровью потребителей, а также совершенствование методов их лабораторного сопровождения.

\section{Список литературы}

1. Абдуллаева Л.В. Контроль показателей безопасности молока и молочной продукции // Молочная промышленность. - 2013. - № 2. - С. 53-54.

2. В Казахстане уничтожено порядка 100 тонн недоброкачественной продукции / Госсанэпиднадзор. URL: http: //www.primeminister.kz/news/show/25/v-kazahstane-unichtozheno-porjadka-100-tonn-nedobrokachestvennoj-produktsii-gossanepidnadzor-/13-06-2013? lang=ru (дата обращения: 15.08.2015).

3. О государственной регистрации отдельных видов продукции, представляющих потенциальную опасность для человека, а также отдельных видов продукции, впервые ввозимых на территорию Российской Федерации»: Постановление правительства РФ № 262 от 4 апр. 2001 г. // КонсультантПлюс.

4. О защите прав потребителей в Российской Федерации в 2014 году: государственный доклад. - М.: Федеральная служба в сфере защиты прав потребителей и благополучия человека Российской Федерации, 2015. - $308 \mathrm{c}$.

5. О применении санитарных мер в Таможенном союзе: решение Комиссии Таможенного союза № 299 от 28 мая 2010 г. - URL: http: //www.alta.ru/tamdoc/10sr0299 (дата обращения: 11.08.2015).

6. О санитарно-эпидемиологической обстановке в Республике Беларусь в 2014 году: Государственный доклад. - Минск. Министерство здравоохранения Республики Беларусь, 2015. - 193 с.

7. Об итогах взаимной торговли товарами Евразийского экономического союза. - URL: http: //www.eurasiancommission.org/ru/act/integr_i_makroec/dep_stat/tradestat/analytics/Documents/Analytics_I_201506.pdf (дата обращения: 11.08.2015).

8. Об установлении перечня продукции, представляющей потенциальную опасность для жизни и здоровья населения и признании утратившими силу некоторых постановлений Министерства здравоохранения Республики Беларусь: постановление Министерства здравоохранения Республики Беларусь № 57 от 5 июня 2012 г. http://www.levonevski.net/pravo/norm2013/num04/d04664.html (дата обращения: 05.09.2015).

9. Самойленко Н.П., Ястребова А.И., Белинская Н.Г. Национальные стандарты для контроля качества и безопасности табачной продукции // Стандарты и качество. - 2010. - № 9. - С. 32-34.

10. Слапогузова 3.В. Контроль качества и безопасности копченой рыбной продукции // Рыбпром: технологии и оборудование для переработки водных биоресурсов. - 2009. - № 2. - С. 18-22.

11. Шелищ П.Б. Надежные измерения - основа контроля качества и безопасности продукции // Контроль качества продукции. - 2014. - № 10. - С. 61-63. 


\section{References}

1. Abdullaeva L.V. Kontrol' pokazatelej bezopasnosti moloka i molochnoj produkcii [Control of milk and milk products' safety indicators]. Molochnaja promyshlennost', 2013, no. 2, pp. 53-54.

2. V Kazahstane unichtozheno porjadka 100 tonn nedobrokachestvennoj produkcii - Gossanjepidnadzor [In Kazakhstan, about 100 tons of substandard products are destroyed - Gossanepidnadzor]. Available at: http://www. primeminister.kz/news/show/25/v-kazahstane-unichtozheno-porjadka-100-tonn-nedobrokachestvennoj-produktsiigossanepidnadzor-/13-06-2013?lang=ru.

3. O gosudarstvennoj registracii otdel'nyh vidov produkcii, predstavljajushhih potencial'nuju opasnost' dlja cheloveka, a takzhe otdel'nyh vidov produkcii, vpervye vvozimyh na territoriju Rossijskoj Federacii». Postanovlenie pravitel'stva RF ot 04 apr. 2001 g. № 262 [On state registration of certain types of products that pose a potential danger to humans, as well as certain types of products, for the first time imported to the territory of the Russian Federation. RF Government Decree dated April 4. 2001 № 262].

4. O zashhite prav potrebitelej v Rossijskoj Federacii v 2014 godu: gosudarstvennyj doklad [On consumer protection in the Russian Federation in 2014: state report]. Moscow: Federal'naja sluzhba v sfere zashhity prav potrebitelej i blagopoluchija cheloveka Rossijskoj Federacii, 2015. 308 p.

5. Reshenie Komissii Tamozhennogo sojuza of 28 maja 2010 g. № 299 «O primenenii sanitarnyh mer v Tamozhennom sojuze» [The decision of the Customs Union Commission dated May 28, 2010 № 299 “On the application of sanitary measures in the Customs Union"]. Available at: http://www.alta.ru/tamdoc/10sr0299/.

6. O sanitarno-jepidemiologicheskoj obstanovke v Respublike Belarus' v 2014 godu: Gosudarstvennyj doklad [On the sanitary-epidemiological situation in the Republic of Belarus in 2014: state report]. Minsk: Ministerstvo zdravoohranenija respubliki Belarus', 2015. 193 p.

7. Ob itogah vzaimnoj torgovli tovarami Evrazijskogo jekonomicheskogo sojuza [On the results of the mutual trade of the Eurasian Economic Union]. Available at: http://www.eurasiancommission.org/ru/act/integr_i_makroec/dep_stat/tradestat/analytics/Documents/Analytics_I_201506.pdf

8. Ob ustanovlenii perechnja produkcii, predstavljajushhej potencial'nuju opasnost' dlja zhizni i zdorov'ja naselenija i priznanii utrativshimi silu nekotoryh postanovlenij Ministerstva zdravoohranenija Respubliki Belarus': postanovlenie Ministerstva Zdravoohranenija Respubliki Belarus' ot 05 ijunja 2012 g. № 57. [On establishing the list of products posing a potential danger to life and health, and repeal of some regulations of Ministry of Health of the Republic of Belarus: the decision of the Ministry of Health of the Republic of Belarus dated 5 June 2012 № 57].

9. Samoylenko N.P., Jastrebova A.I., Belinskaja N.G. Nacional'nye standarty dlja kontrolja kachestva i bezopasnosti tabachnoj produkcii [National standards for quality control and safety of tobacco products]. Standarty $i$ kachestvo, 2010, no. 9, pp. 32-34.

10. Slapoguzova Z.V. Kontrol' kachestva i bezopasnosti kopchenoj rybnoj produkcii [Quality control and safety of smoked fish products]. Rybprom: tehnologii i oborudovanie dlja pererabotki vodnyh bioresursov, 2009, no. 2, pp. 18-22.

11. Shelishh P.B. Nadezhnye izmerenija - osnova kontrolja kachestva i bezopasnosti produkcii [Reliable measurements - the basis for quality control and product safety]. Kontrol' kachestva produkcii, 2014, no. 10, pp. 61-63. 


\title{
ON THE ISSUE OF SETTING PRIORITIES IN THE ORGANIZATION OF RISK-BASED SUPERVISION OVER THE SAFETY OF CONSUMER PRODUCTS TRADED ON THE COMMON ECONOMIC SPACE OF RUSSIA, BELARUS AND KAZAKHSTAN
}

\author{
A.Yu. Popova ${ }^{1}$, N.V.Zaitseva ${ }^{2}$, I.V. May ${ }^{2}$, P.Z. Shur ${ }^{2}$ \\ ${ }^{1}$ Federal Service for Supervision of Consumer Rights Protection and Human Surveillance, \\ Russian Federation, Moscow, 18, building 5 and 7, Vadkovsky lane, 127994 \\ ${ }^{2}$ FBSI "Federal Scientific Center for Medical and Preventive Health Risk Management Technologies", \\ Russian Federation, Perm, 82 Monastyrskaya St., 614045
}

Significant volumes of mutual trade between the countries of the Eurasian Economic Union, combined with the urgency of protecting the population against the risks of negative impacts on the health products are aiming to optimize the supervision of the products traded in the market. One of the ways to optimize is the transition to a risk-based model of health service activities and choice of products for top-priority (priority) control. The approaches to the selection of priorities are offered, based on the account of the product use, consumer contingent specificity, known types of hazards, results of inspection and enforcement activities. It was found that the priority products exported by EASE member countries on the common market and forming potentially the greatest risk of harm to the health of consumers may include: dairy products; bird eggs (FEACN group 04); fats and oils of animal or vegetable origin and their cleavage products; prepared edible fats; waxes of animal or vegetable origin (FEACN group 15); sugar and sugar confectionery (FEACN group 17); meat, fish or crustaceans, mollusks or other aquatic invertebrates (FEACN group 16); alcoholic and soft drinks and so on. (FEACN group 22); vegetables, roots and tubers (FEACN group 07); toys, games and sports equipment (FEACN group 95). In relation to these groups of products the priority study of the risk profile required, as well as the development of algorithms and regulations of the supervisory and control measures and improvement of laboratory support methods.

Key words: consumer goods, security, risk-based supervision.

(C) Popova A.Yu., Zaitseva N.V., May I.V., Shur P.Z., 2015

Popova Anna Urievna - MD in Medicine, Professor, Head, Chief State Medical Officer of the Russian Federation (e-mail: depart@gsen.ru; tel. 8 (499) 973-26-90).

Zaitseva Nina Vladimirovna - Academician of the Russian Academy of Medical Sciences, MD, Professor, Director (e-mail: znv@fcrisk.ru; tel.: 8 (342) 237-25-34).

Mai Irina Vladislavovna - DBS, Professor, Deputy Director for Science (e-mail: may@fcrisk.ru; tel. 8 (342) 237-25-47).

Shur Pavel Zalmanovich - MD, Secretary of the Academic Council (e-mail: shur@fcrisk.ru; tel. 8 (342) 238-33-37). 


\title{
ПРАВОВЫЕ АСПЕКТЫ ОЦЕНКИ РИСКА
}

УДК 614.447.6-027.45-004.413.4 (4) (476)

\section{ПРАВОВЫЕ ОСНОВЫ ПРИМЕНЕНИЯ МЕТОДОЛОГИИ АНАЛИЗА РИСКА ПРИ ОБЕСПЕЧЕНИИ БЕЗОПАСНОСТИ ПИЩЕВОЙ ПРОДУКЦИИ В ЕВРАЗИЙСКОМ ЭКОНОМИЧЕСКОМ СОЮЗЕ И РЕСПУБЛИКЕ БЕЛАРУСЬ}

\author{
Е.В. Федоренко \\ РУП «Научно-практический центр гигиены», \\ Республика Беларусь, 220012, г. Минск, ул. Академическая, 8
}

\begin{abstract}
Методология анализа риска здоровью населения является признанным на международном уровне инструментом обеспечения безопасности пищевой продукции. Три основных элемента анализа риска - оценка риска, управление риском и информирование заинтересованных о риске законодательно закреплены и реализуются как в Евразийском экономическом союзе, так и в Республике Беларусь. Существует соответствующая организационная и функииональная основа для применения методологии анализа риска как при обосновании показателей безопасности продукции, так и при осуществлении государственного санитарного надзора. Определены единые методические подходы и критерии оценки риска здоровью населения, которые используются при разработке и применении требований безопасности пищевой продукции. Оценка риска учитывается при обосновании показателей безопасности (контаминанть, пищевье добавки) и оченке эффективности программ обогащения пищевой продукции микронутриентами.

Ключевые слова: анализ риска, оченка риска здоровью, нормативно-правовая база, безопасность пищевой продукции.
\end{abstract}

Безопасность продовольственного сырья и пищевой продукции является одной из актуальных проблем общественного здравоохранения. Ущерб от наиболее распространенных пищевых отравлений (микробной и химической природы) оценивается в мировом масштабе в сотни миллионов долларов и поэтому, исходя из своей социальной значимости, обеспечение безопасности пищевой продукции является не только актуальной областью медицины, но и затрагивает другие сферы экономической деятельности. Учитывая ограничительный характер мероприятий, направленных на профилактику широкого спектра заболеваний, связанных с пищевыми продуктами (состояния микронутриентной недостаточности, пищевые отравления и интоксикации различного генеза), и высокую стоимость мер по реализации требований, обеспечивающих безопасность, применение методов количественной оценки воздействия отдельных неблагоприятных факторов, связанных с пищевой продукцией, на здоровье населения является актуальным.
В соответствии с подходами, признанными на международном и европейском уровнях (Coглашение по применению санитарных и фитосанитарных мер Всемирной торговой организации (BTO) [9], стандарты Комиссии Codex Alimentarius [12], регламент Европейского союза № 178/2002 от 28 января 2002 г., устанавливающий общие принципы и требования продовольственного права [13]), меры по обеспечению безопасности пищевой продукции должны реализовываться с применением методологии анализа риска.

Три взаимосвязанных элемента анализа риска - оценка риска, управление риском и обмен информацией о рисках - представляют собой системную методологию определения действенных, соразмерных и целевых мер или других действий для охраны здоровья потребителей, связанных с пищевой продукцией. Оценка риска - научная экспертная методология, которая позволяет определить степень риска для здоровья населения вследствие наличия потенциально опасных факторов в пи-

(C) Федоренко Е.В., 2015

Федоренко Екатерина Валерьевна - кандидат медицинских наук, доцент, заведующий лабораторией изучения статуса питания населения (e-mail: afedorenko71@mail.ru; тел. +375 1728413 70). 
щевой продукции - контаминантов, патогенных микроорганизмов, пищевых добавок, обогащающих компонентов. На основании данных по оценке риска обосновываются и реализуются управленческие решения по обеспечению безопасности пищевой продукции (управление риском). Информация о риске при необходимости направляется заинтересованным лицами - изготовителям продукции в другие органы государственного управления, потребителям (информирование о риске).

В настоящее время законодательство Евразийского экономического союза в целом содержит элементы анализа риска. Приложение 12 «Протокол о применении санитарных, ветеринарно-санитарных и карантинных фитосанитарных мер» к Договору о Евразийском экономическом союзе определяет оценку риска как ключевой инструмент санитарно-противоэпидемических мероприятий, реализация которых направлена на устранение или уменьшение такого риска, предотвращение возникновения и распространения инфекционных и массовых неинфекционных болезней (отравлений) и их ликвидацию, что является по своей сути управлением риском [1].

Понятие «риск» в законодательстве Евразийского экономического союза не является специфическим по отношению к пищевой продукции и в целом соответствует принятым международным подходам в обсуждаемой области. Приложение 9 «Протокол о техническом регулировании в рамках Евразийского экономического союза» к Договору о Евразийском экономическом союзе определяет риск как сочетание вероятности причинения вреда и последствий этого вреда для жизни или здоровья человека (в части санитарно-эпидемиологического благополучия населения) [1].

Положением о порядке осуществления государственного санитарно-эпидемиологического надзора (контроля) за лицами и транспортными средствами, пересекающими таможенную границу Таможенного союза, под- контрольными товарами, перемещаемыми через таможенную границу Таможенного союза и на таможенной территории Таможенного союза, утвержденном решением Комиссии Таможенного союза № 299 от 28 мая 2010 г., по сути закреплены подходы по управлению риском, связанным с пищевой продукцией, которые реализуют органы, уполномоченные в области санитарно-эпидемиологического благополучия населения, равно как и информирование о риске [8].

Техническим регламентом Таможенного союза «О безопасности пищевой продукции» ТР ТС 021/2011 установлено, что безопасность пищевой продукции - это состояние пищевой продукции, свидетельствующее об отсутствии недопустимого риска, связанного с вредным воздействием на человека и будущие поколения [4].

Законом Республики Беларусь № 340-3 от 7 января 2012 г. «О санитарно-эпидемиологическом благополучии населения» определено, что санитарно-противоэпидемические мероприятия - это организационные, профилактические и иные мероприятия, направленные на оценку риска неблагоприятного воздействия на организм человека факторов среды его обитания, устранение или уменьшение такого воздействия [6]. Статья 19 указанного Закона и «Положение о порядке проведения социальногигиенического мониторинга», утвержденное постановлением Министерства здравоохранения Республики Беларусь № 105 от 17 июля 2012 г. [7], закрепляют в качестве целей социально-гигиенического мониторинга выявление уровней риска для жизни и здоровья населения и разработку мероприятий, направленных на предупреждение, уменьшение и устранение неблагоприятного воздействия на организм человека факторов среды его обитания. Отдельные задачи осуществления социально-гигиенического мониторинга в республике фактически формируют методологию анализа риска (таблица).

Отдельные элементы анализа риска, законодательно установленные в Республике Беларусь [7]

\begin{tabular}{|l|l|l|}
\hline \multicolumn{1}{|c|}{ Оценка риска } & \multicolumn{1}{|c|}{ Управление риском } & \multicolumn{1}{|c|}{ Информирование о риске } \\
\hline Идентификация факторов, оказы- & Обоснование, разработка и организация выполне- & Координация межведомственной \\
вающих вредное воздействие на & ния программ по вопросам обеспечения санитар- & деятельности; информирование госу- \\
человека, путем выявления причин- & но-эпидемиологического благополучия и охраны & дарственных органов, юридических \\
но-следственных связей между & здоровья населения, профилактики заболеваний и & и физических лиц, в том числе инди- \\
состоянием здоровья и воздействи- & оздоровления; подготовка предложений для при- \\
ем факторов среды обитания; & вятия органами государственного управления & зультатах, полученных в ходе мони- \\
прогнозирование состояния здоро-- & необходимых мер по устранению выявленных & торинга \\
вья населения & ведных воздействий факторов среды обитания & \\
\hline
\end{tabular}


В настоящее время подготовлена новая редакция Закона Республики Беларусь «О качестве и безопасности продовольственного сырья и пищевых продуктов для жизни и здоровья человека», которая содержит основные определения таких терминов, как «риск», «анализ риска», и отдельных его компонентов, а также предполагает использование анализа рисков при государственном контроле и надзоре в области обеспечения безопасности пищевой продукции [5].

Функциональная модель применения указанной методологии в Республике Беларусь приведена на рисунке.

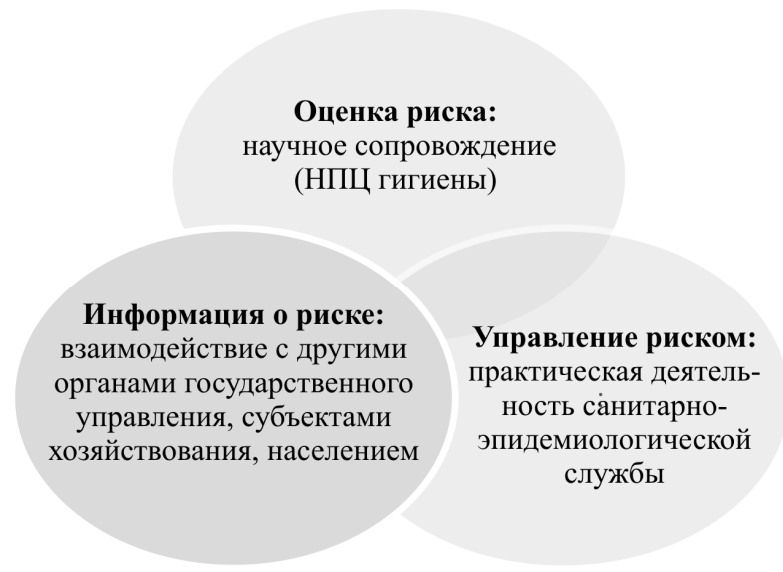

Рис. Модель применения методологии анализа риска при обеспечении безопасности пищевой продукции в Республике Беларусь

Методология оценки риска здоровью, связанного с продукцией, в том числе пищевой, как неотъемлемый элемент анализа риска активно развивается научным сообществом государств членов Евразийского экономического союза и в Республике Беларусь. Разработанная Евразийской экономической комиссией при участии специалистов Российской Федерации, Республики Беларусь и Республики Казахстан методология оценки рисков здоровью населения при воздействии химических, физических и биологических факторов для определения показателей безопасности продукции (товаров) устанавливает единые подходы и критерии оценки риска здоровью населения и будет использоваться при разработке и применении требований безопасности продукции [3]. Это направление совместной работы крайне актуально, поскольку согласно Договору о Евразийском экономическом союзе [1] принятие национальных гигиенических нормативов, отличных от принятых в Евразийском экономическом союзе, регламенти- рующих требования безопасности пищевой продукции, не представляется возможным.

Таким образом, методология анализа риска в целом реализована в законодательстве и методических документах Евразийского экономического союза - единые методические подходы по оценке риска установлены [3], управление и информирование о риске осуществляется согласно [8].

Применение оценки риска при обеспечении безопасности пищевой продукции вытекает из Договора о Евразийском экономическом союзе [1] и является обязательным для государств - членов ВТО. Статья 5 Соглашения ВТО по применению санитарных и фитосанитарных мер определяет: «Члены обеспечивают, чтобы в основу их санитарных мер (требований безопасности пищевой продукции) была положена соответствующая обстоятельствам оценка рисков для жизни или здоровья людей, осуществляемая с учетом методов оценки риска, разработанных соответствующими международными организациями» [9].

В целом методология оценки риска как научная экспертная методология в области обеспечения безопасности пищевой продукции может использоваться:

- при обосновании показателей безопасности пищевой продукции в отношении биологических агентов, химических веществ - контаминантов, пищевых добавок, пестицидов, оценке безопасности и эффективности программ ликвидации отдельных видов микронутриентной недостаточности;

- для ранжирования объектов с точки зрения осуществления надзорной деятельности на основе комплекса факторов в зависимости от риска для здоровья потребителей, формируемого выпускаемой продукцией;

- при размещении объектов для обоснования санитарно-защитной зоны на этапе предупредительного санитарного надзора.

В Республике Беларусь разработаны гармонизированные с международными методические подходы, которые определяют алгоритм и критерии оценки риска здоровью населения вследствие наличия в пищевой продукции контаминантов, биологически активных компонентов и пищевых добавок.

В отношении показателей безопасности Республика Беларусь придерживается гигиенических нормативов, принятых в Евразийском экономическом союзе. Методология оценки риска нашла свое практическое применение 
при оценке эффективности программы профилактики йоддефицитных заболеваний [2] и оценке безопасности использования некоторых пищевых добавок [10, 11].

Программа профилактики йоддефицитных заболеваний действует в Республике Беларусь с 2000 г., и одним из ее компонентов являлось обязательное использование йодированной соли при изготовлении пищевой продукции промышленного производства (за исключением продукции из морской рыбы, морепродуктов). В таких обстоятельствах у отдельных потребителей существует вероятность поступления биологически активного компонента в количествах, превышающих верхний безопасный уровень поступления. Поэтому была проведена качественная оценка риска здоровью, связанного с потенциальным избыточным поступлением йода с рационом, среди взрослого населения: обоснованы различные сценарии поступления указанного микронутриента с рационом, учитывавшие уровни содержания йода в пищевой продукции, средние и высокие уровни потребления пищевой продукции, долю обогащенной продукции на рынке. Полученные данные показали, что изготовление пищевой продукции массового потребления (хлебобулочные, колбасные изделия) с использованием йодированной соли способствует адекватной обеспеченности йодом населения и не приводит к избыточному его поступлению в организм даже в агравированных сценариях. Полученные данные подтвердили безопасность проводимого обязательного обогащения йодом пищевой продукции массового потребления путем использования йодированной соли [2].

Надежность гигиенических регламентов применения пищевых добавок проанализирована в отношении нитритов. Поступление нитритов с рационом было оценено в рамках реалистичного сценария, а также для индивидуумов с высокими уровнями потребления колбасных изделий - основных источников обсуждаемых химических соединений. Полученные данные свидетельствуют об отсутствии превышения допустимого суточного поступления нитритов для взрослых потребителей с обычными уровнями потребления колбасных изделий. Однако в случае использования агравированных моделей алиментарная экспозиция нитритами была значительной, что свидетельствовало о наличии недопустимого риска для таких потребителей. При этом больший вклад в формирование такой нагрузки вносило не столько применение пищевой добавки, сколько уровни потребления пищевых продуктов, в производстве которых они используются [11].

Таким образом, в целом методология анализа риска при обеспечении безопасности пищевой продукции в Евразийском экономическом союзе и Республике Беларусь закреплена законодательно, существует соответствующая функциональная основа для ее реализации, проводится работа по разработке и совершенствованию единых методических подходов по оценке риска здоровью населения при воздействии химических, физических и биологических факторов для обеспечения безопасности пищевой продукции.

\section{Список литературы}

1. Договор о Евразийском экономическом союзе / Евразийская экономическая комиссия [Электронный pecypc]. - 2015. - URL: http: //www.eurasiancommission.org/ru (дата обращения: 01.04.2014).

2. Коломиец Н.Д. Оценка эффективности программ профилактики йоддефицитных заболеваний в Республике Беларусь // Здоровье и окружающая среда: сб. науч. тр. / М-во здравоохранения Республики Беларусь; науч.-практ. центр гигиены; гл. ред. С.И. Сычик. - Минск: РНМБ, 2014. - Т. 2, вып. 24. - С. 170-173.

3. Методология оценки рисков здоровью населения при воздействии химических, физических и биологических факторов для определения показателей безопасности продукции (товаров). - М.: Юманите медиа, 2014. - $120 \mathrm{c}$.

4. О безопасности пищевой продукции (ТР ТС 021/2011) / Комиссия Таможенного союза [Электронный pecypc]. - 2014. - URL: http: //www. eurasiancommission.org/ru/db/techreglam/Documents/TR \% 20TS \% 20bezopProd.pdf (дата обращения: 01.04.2015).

5. О качестве и безопасности продовольственного сырья и пищевых продуктов для жизни и здоровья человека: Закон Республики Беларусь № 217-3 от 29 июня 2003 г. / Министерство здравоохранения Республики Беларусь [Электронный ресурс]. - 2015. - URL: http: //minzdrav.gov.by/ru/static/acts/normativnye/zakony. (дата обращения: 01.04.2015).

6. О санитарно-эпидемиологическом благополучии населения: Закон Республики Беларусь № 340-3 от 7 января 2012 г. / Министерство здравоохранения Республики Беларусь [Электронный ресурс]. - 2015. URL: http: //minzdrav.gov.by/ru/static/acts/normativnye/zakony (дата обращения: 01.04.2015). 
7. Положение о порядке проведения социально-гигиенического мониторинга / Министерство здравоохранения Республики Беларусь [Электронный ресурс]. - 2015. - URL: http: //minzdrav.gov.by/ru/static/ acts/normativnye/postanovlenia_ ministerstva/o-sotsialno-gigienicheskom-monitoringe_i_1612.html. (дата обращения: 30.05.2015).

8. Положение о порядке осуществления государственного санитарно-эпидемиологического надзора (контроля) за лицами и транспортными средствами, пересекающими таможенную границу Таможенного союза, подконтрольными товарами, перемещаемыми через таможенную границу Таможенного союза и на таможенной территории Таможенного союза / Комиссия Таможенного союза [Электронный pecypc]. - 2010. - URL: http: //www.tsouz.ru/db/techregulation/sanmeri/Documents (дата обращения: 30.03.2015).

9. Соглашение ВТО по применению санитарных и фитосанитрных мер / World Trade Organization [Electronic resource]. - 2011. - URL: http: //www.wto.org. (дата обращения: 20.03.2015).

10. Федоренко Е.В., Коломиец Н.Д. Подходы к оценке алиментарной нагрузки пищевыми добавкам // Гигиена и санитария. - 2013. - № 1. - С. 40-41.

11. Федоренко Е.В., Шуляковская О.В., Бордак Л.В. Гигиеническая оценка алиментарной нагрузки пищевыми добавками (на примере нитритов) // Здоровье и окружающая среда [Электронный ресурс]: сб. науч. тр. / Министерство здравоохранения Республики Беларусь, Респ. науч.-практ. центр гигиены, Бел. науч. о-во гигиенистов; редкол.: Л.В. Половинкин (гл. ред.) [и др.]. - Минск, 2014. - Вып. 21. - С. 617-623.

12. Codex Alimentarius Commission. Working principles for risk analysis for food safety for application by governments / WHO Food Standards Programme, Food and Agriculture Organization of the United Nations [Electronic resource]. - URL: http: //www.codexalimentarius.org/download/standards/394/CXG_50e.pdf. (дата обращения: 20.03.2015).

13. Regulation (EC) no 178/2002 of the European Parliament and of the Council of 28 January 2002 laying down the general principles and requirements of food law, establishing the European Food Safety Authority and laying down procedures in matters of food safety / Access to European Union law [Electronic resource]. - 2014. URL: http: //eur-lex.europa.eu/legal-content/EN/TXT/PDF/? uri=CELEX: 32002R0178\&qid=1429076106145. (дата обращения: 20.03.2015).

\section{References}

1. Dogovor o Evrazijskom jekonomicheskom sojuze [Treaty on the Eurasian Economic Union]. Evrazijskaja jekonomicheskaja Komissija. 2015. Available at: http: //www.eurasiancommission.org/ru.

2. Kolomiec N.D. Ocenka jeffektivnosti programm profilaktiki joddeficitnyh zabolevanij v Respublike Belarus' [Assessment of programs effectiveness for prevention of iodine deficiency diseases in the Republic of Belarus]. Zdorov'e i okruzhajushhaja sreda: sbornik nauchnyh trudov. Ministerstvo zdravoohranenija Respubliki Belarus'; Nauchno-prakticheskij centr gigieny; gl. red. S.I. Sychik. Minsk: RNMB, 2014, vol. 2, issue 24, pp. 170-173.

3. Metodologija ocenki riskov zdorov'ju naselenija pri vozdejstvii himicheskih, fizicheskih i biologicheskih faktorov dlja opredelenija pokazatelej bezopasnosti produkcii (tovarov) [Risk assessment methodology to human health under the influence of chemical, physical and biological factors for definition of safety indicators of products (goods)]. Moscow: Jumanite media, 2014. 120 p.

4. O bezopasnosti pishhevoj produkcii (TR TS 021/2011) [On the safety of food products (TR CU 021/2011)]. Komissija Tamozhennogo sojuza. 2014. Available at: http: //www.eurasiancommission.org/ru/db/techreglam/Documents/TR \% 20TS \% 20bezopProd.pdf.

5. O kachestve i bezopasnosti prodovol'stvennogo syr'ja i pishhevyh produktov dlja zhizni i zdorov'ja cheloveka: zakon Respubliki Belarus' ot 29 ijunja 2003 g. № 217-Z [On quality and safety of alimentary raw materials and alimentary products for human life and health: law of the Republic of Belarus dated June29, 2003 No.217Z]. Ministerstvo zdravoohranenija Respubliki Belarus'. 2015. Available at: http: //minzdrav.gov.by/ru/static/acts/normativnye/zakony.

6. O sanitarno-jepidemiologicheskom blagopoluchii naselenija: Zakon Respubliki Belarus' ot 7 janvarja 2012 g. № 340-Z [On sanitary and epidemiological welfare of the population: Law of the Republic of Belarus dated $7^{\text {th }}$ of January, 2012 No.340-Z]. Ministerstvo zdravoohranenija Respubliki Belarus'. 2015. Available at: http: // minzdrav.gov.by/ru/static/acts/normativnye/zakony.

7. Polozhenie o porjadke provedenija social'no-gigienicheskogo monitoringa [Regulations on procedure for environment and health monitoring]. Ministerstvo zdravoohranenija Respubliki Belarus'. 2015. Available at: http: //minzdrav.gov.by/ru/static/acts/normativnye/postanovlenia_ministerstva/o-sotsialno-gigienicheskom-monitoringe_i_1612.html.

8. Polozhenie o porjadke osushhestvlenija gosudarstvennogo sanitarno-jepidemiologicheskogo nadzora (kontrolja) za licami i transportnymi sredstvami, peresekajushhimi tamozhennuju granicu Tamozhennogo sojuza, 
podkontrol'nymi tovarami, peremeshhaemymi cherez tamozhennuju granicu Tamozhennogo sojuza i na tamozhennoj territorii Tamozhennogo sojuza [Regulations on procedure for state sanitary and epidemiological supervision (control) over individuals and vehicles crossing the customs border of the Customs Union, controlled goods transported across the customs border of the Customs Union and on customs territory of the Customs Union]. Komissija Tamozhennogo sojuza. 2010. Available at: http: //www.tsouz.ru/db/techregulation/sanmeri/Documents.

9. Soglashenie VTO po primeneniju sanitarnyh i fitosanitrnym meram [WTO Agreement on application of sanitary and phytosanitary measures]. World Trade Organization, 2011. Available at: http: //www.wto.org.

10. Fedorenko E.V., Kolomiec N.D. Podhody k ocenke alimentarnoj nagruzki pishhevymi dobavkam [Approaches to assessment of alimentary load to nutritionals]. Gigiena i sanitarija, 2013, no. 1, pp. 40-41.

11. Fedorenko, E.V., Shuljakovskaja O.V., Bordak L.V. Gigienicheskaja ocenka alimentarnoj nagruzki pishhevymi dobavkami (na primere nitritov) [Hygienic assessment of nutritional load of nutritionals (in case of nitrites) ]. Zdorov'e i okruzhajushhaja sreda: sb. nauch. tr. Ministerstvo zdravoohranenija Respubliki Belarus', Respublikanskij nauchno-prakticheskij centr gigieny, Belorusskoe nauchnoe obshhestvo gigienistov; redkol.: L.V. Polovinkin (gl. red.) [i dr.], Minsk, 2014, issue 21, pp. 617-623.

12. Codex Alimentarius Commission. Working principles for risk analysis for food safety for application by governments. WHO Food Standards Programme, Food and Agriculture Organization of the United Nations. Available at: http: //www.codexalimentarius.org/download/standards/394/CXG_50e.pdf.

13. Regulation (ES) no 178/2002 of the European Parliament and of the Council of 28 January 2002 laying down the general principles and requirements of food law, establishing the European Food Safety Authority and laying down procedures in matters of food safety. Access to European Union law. 2014. Available at: http: //eurlex.europa.eu/legal-content/EN/TXT/PDF/?uri=CELEX: 32002R0178\&qid=1429076106145.

\title{
LEGAL BASIS FOR RISK ANALYSIS METHODOLOGY WHILE ENSURING FOOD SAFETY IN THE EURASIAN ECONOMIC UNION AND THE REPUBLIC OF BELARUS
}

\author{
E.V. Fedorenko \\ RUE “Scientific and Practical Center of Hygiene”, Republic of Belarus, Minsk, 8 Akademicheskaya St., 220012
}

Health risk analysis methodology is an internationally recognized tool for ensuring food safety. Three main elements of risk analysis are risk assessment, risk management and risk communication to inform the interested parties on the risk, are legislated and implemented in the Eurasian Economic Union and the Republic of Belarus. There is a corresponding organizational and functional framework for the application of risk analysis methodology as in the justification of production safety indicators and the implementation of public health surveillance. Common methodological approaches and criteria for evaluating public health risk are determined, which are used in the development and application of food safety requirements. Risk assessment can be used in justifying the indicators of safety (contaminants, food additives), and evaluating the effectiveness of programs on enrichment of food with micronutrients.

Key words: risk analysis, risk assessment, health, legal and regulatory framework, food safety.

(C) Fedorenko E.V., 2015

Fedorenko Ekaterina Valeryevna - Candidate of Medicine, Associate Professor, Head of the Laboratory studying the population nutritional status (e-mail: afedorenko71@mail.ru; tel. +375 17284 13 70). 


\section{НАУЧНО-МЕТОДИЧЕСКИЕ ПОДХОДЫ К АНАЛИЗУ РИСКА В ГИГИЕНЕ И ЭПИДЕМИОЛОГИИ}

УДК $614.1+316.12$

\section{МЕТОДИЧЕСКИЕ ПОДХОДЫ И ПРАКТИКА ОЦЕНКИ РИСКА, СВЯЗАННОГО С ВОЗДЕЙСТВИЕМ СОЦИАЛЬНО-ЭКОНОМИЧЕСКИХ ФАКТОРОВ НА ПОПУЛЯЦИОННОЕ ЗДОРОВЬЕ В РЕГИОНАХ РОССИИ}

\section{Н.А. Лебедева-Несевря, М.Ю. Цинкер}

ФБУН «Федеральный научный центр медико-профилактических технологий управления рисками здоровью населения», Россия, 614045, г. Пермь, ул. Монастырская, 82

Предложены алгоритм и методы оценки рисков ухудшений популячионного здоровья населения, связанных с воздействием социально-экономических факторов макроуровня. Методика апробирована на материалах по 78 субъектам Российской Федерачии за 2010-2013 г2. Установлен высокий уровень риска в отношении показателей «младенческая смертность», «заболеваемость болезнями системы кровообращения» и «смертность населения от инфекционных и паразитарных заболеваний» в ряде регионов РФ. Показано, что сочиально детерминированный риск здоровью в большинстве субъектов РФ находится на среднем уровне, что определяет необходимость оперативных мероприятий по его снижению.

Ключевые слова: сочиально-экономические факторы, риск, здоровье населения.

В современных условиях эффективное управление стратегическим развитием страны, региона, территории, ориентированное на принципы устойчивости, расценивающее здоровье населения как ключевой ресурс, невозможно без четкого понимания процессов его формирования.

Потери здоровья населения наиболее часто связываются с уровнем антропогенной нагрузки на окружающую среду. Однако негативные тенденции развития медико-демографической ситуации во многом определяются факторами иной, социальной природы. Масштаб урбанизации и социально-экономического развития территорий, уровень и качество жизни, благосостояние населения, развитость социальной инфраструктуры выступают значимыми детерминантами заболеваемости и смертности в современной России. Перечисленные факторы являются управляемыми, что придает их анализу важное практическое значение, ориентирует на формирование эффективной политики в области сохранения и укрепления здоровья граждан [9].
Большинство отечественных исследований влияния социально-экономических факторов макроуровня на популяционное здоровье ограничиваются лишь описанием корреляции отдельных социально-экономических и медикодемографических показателей. Ни характер связи, ни риски для здоровья населения не обозначаются. Так, в ряде работ установлено, что смертность населения имеет корреляционную связь с безработицей $[2-4,6]$ и валовым региональным продуктом (ВРП) на душу населения $[3,5,8]$, но далее зависимость не исследуется. При этом наблюдается сильный разброс в значениях коэффициентов корреляции - от слабой до сильной связи.

Типичным является использование отдельных частных показателей не только для характеристики медико-демографической ситуации и здоровья населения, но и для описания самих социально-экономических факторов. Тем самым совершается опасная редукция: уровень социально-экономического развития территории сводится к показателю ВРП на ду-

(C) Лебедева-Несевря Н.А., Цинкер М.Ю., 2015

Лебедева-Несевря Наталья Александровна - доктор социологических наук, заведующий лабораторией методов анализа социальных рисков (e-mail: natnes@fcrisk.ru; тел. 8 (342) 237-25-47).

Цинкер Михаил Юрьевич - младший сотрудник отдела математического моделирования систем и процессов (e-mail: cinker@fcrisk.ru; тел. 8 (342) 237-18-04). 
шу населения, уровень жизни населения к среднедушевым денежным доходам, а качество здравоохранения - к числу врачей на душу населения.

Методология анализа риска и результаты ее применения могут составить действенную основу управления человеческим потенциалом и служить опорой при определении ключевых направлений социально-экономической политики $[1,7]$.

Цель исследования - разработать алгоритм и методы оценки рисков популяционного здоровья населения, связанных с воздействием социально-экономических факторов макроуровня, и апробировать предложенную методику на примере регионов России.

Материалы и методы. Оценка риска, связанного с воздействием социально-экономических факторов на здоровье населения, предполагает реализацию четырех взаимосвязанных этапов: 1) идентификация опасности; 2) оценка зависимости «фактор - эффект»; 3) оценка экспозиции; 4) характеристика риска.

На этапе идентификации опасности при отборе конкретных показателей социальноэкономических факторов и здоровья для включения в процедуру оценки риска в качестве источников для формирования перечня показателей использовались базы статистических данных (интерактивный банк медико-санитарных данных Глобальной обсерватории здоровья ВО3, Центральная база статистических данных (ЦБСД) Росстата, Единая межведомственная информационно-статистическая система (ЕМИСС), База данных показателей муниципальных образований Росстата), ведомственные документы Роспотребнадзора, определяющие перечень показателей, собираемых в рамках системы социально-гигиенического мониторинга, а также нормативные документы, приводящие перечень показателей для оценки эффективности деятельности органов управления различного уровня.

Статистические показатели, характеризующие социально-экономические факторы риска, как правило, многочисленны, но созависимы. С целью их классификации и сокращения числа переменных целесообразно применить процедуру факторного анализа.

Классификация макросоциальных показателей выполнялась на основе «матрицы факторных нагрузок», которая характеризует связь (корреляции) исходных переменных с общими факторами. Фактор определялся группой пока- зателей, с которыми имелись наибольшие абсолютные значения факторных нагрузок. Количество факторов выявлялось в соответствии с критерием Кайзера. Для дальнейшего анализа принимались во внимание факторы с собственными значениями больше единицы. В результате выполнения факторного анализа каждой анализируемой территории (региону) присваивались значения ортогональных (некоррелирующих) факторов. В последующую процедуру анализа включались не отдельные социально-экономические показатели, а комплексные факторы.

Для установления зависимостей «фактор эффект» применялся корреляционно-регрессионный анализ. При использовании данного метода учитывалось, что отклик в состоянии здоровья на изменение макросоциальных факторов не наступает немедленно. Применялся временной лаг в 1 год, т.е. в качестве независимой переменной рассматривали социально-экономические факторы года $N$, тогда как зависимые переменные (нарушение здоровья в виде смертности, заболеваемости, инвалидности и т.п.) принимали за год $N+1)$. Анализировались только достоверные модели $(p<0,05)$.

Для определения влияния каждого из факторов, включенных в анализ, в отдельности, а также их совокупного влияния на моделируемый показатель здоровья строились модели множественной регрессии. Для каждой модели рассчитывался показатель детерминации $R^{2}$, фиксирующий долю объясненной вариации показателя здоровья за счет рассматриваемых в модели социально-экономических факторов. Для определения в наибольшей степени зависимых от данных факторов показателей здоровья, все они ранжировались по критерию $R^{2}$. Для моделей, включающих несколько социально-экономических факторов, рассчитывались частные коэффициенты детерминации для определения долевого вклада вариации отдельных факторов в вариацию показателя здоровья.

Оценка экспозиции социально-экономических факторов выполнялась на основе анализа данных государственной статистики. Положительные стороны ее использования - единство методологической базы сбора данных, масштабность, когда срабатывает закон больших чисел, нивелирующий частные ошибки отдельных исследователей, а также обязательная экспертная оценка данных перед отрытым их опубликованием. Вместе с тем установлено, что наиболее информативным является приме- 
нение относительных показателей, которые позволяют сравнивать между собой совершенно разные регионы (территории, муниципальные образования).

Параметры экспозиции населения к социально-экономическим факторам позволяют оценить среди прочего и количество населения, которое находится под воздействием фактора.

На этапе характеристики риска осуществлялся расчет и классификация риска, связанного с воздействием социально-экономических факторов на здоровье населения. Отправной точкой являлось определение пороговых значений влияния указанных факторов на показатели здоровья. Далее устанавливалась разница показателей заболеваемости/смертности, определенных согласно полученным моделям для текущего значения социально-экономических факторов, и пороговых значений с поправкой на коэффициент детерминации модели.

При количественной оценке риска, связанного с воздействием социально-экономических факторов на популяционное здоровье, расчет риска осуществлялся по формуле

$$
R=\left[y\left(x_{i}\right)-y\left(\hat{x}_{i}\right)\right] R^{2} g_{i},
$$

где $y\left(x_{i}\right)$ - значение показателя нарушения здоровья (заболеваемости, смертности, инвалидизации и пр.) для текущих значений факторов, $y\left(\hat{x}_{i}\right)$ - значение показателя для пороговых значений факторов, $R^{2}$ - коэффициент детерминации модели, $g_{i}$ - тяжесть нарушения здоровья.

Под «пороговым» понимается такое значение фактора, которое является оптимальным в сложившихся общественных условиях. Это может быть наилучшее значение фактора среди всех включенных в анализ при построении математических моделей территорий или среднее значение фактора.

В ряде случаев для расчета целевого уровня могут использоваться величины показателей, определенные стратегическими документами органов государственной власти Российской Федерации.

Поскольку оценка риска, связанного с воздействием социально-экономических факторов на популяционное здоровье населения, осуществлялась в количественной традиции, риск рассчитывался как произведение количества дополнительных случаев нарушений здоровья, рассчитанных на душу населения, на тяжесть данного нарушения:

$$
R=\Delta^{i} g^{i}
$$

где $g^{i}$ - тяжесть нарушения здоровья.

Риск квалифицировался на основе применения аналоговой стратегии (за основу брался подход к градации риска, рекомендованный Всемирной организацией здравоохранении для оценки риска, связанного с воздействием факторов среды обитания на здоровье).

Результаты и их обсуждение. По результатам факторного анализа макросоциальных показателей для регионов РФ было выделено 4 группы социально-экономических факторов макроуровня (табл. 1), характеризующих: $F_{1}$ общий уровень социально-экономического развития территории, $F_{2}-$ условия быта населения; $F_{3}$ - состояние системы здравоохранения и $F_{4}$ - уровень развития социальной инфраструктуры на территории.

На базе использования материалов государственной статистики 78 субъектов Российской Федерации и Федерального информационного фонда Роспотребнадзора за 2010-2013 гг. с применением временного лага 1 год было получено несколько десятков достоверных $(p<0,05)$ парных и множественных моделей, описывающих связь показателей популяционного здоровья и социально-экономических факторов в регионах России. Ряд примеров математических линейных уравнений, характеризующих общероссийские зависимости, приведен ниже:

$$
y_{3}=7,39-1,11 F_{4},
$$

где $y_{3}$ - младенческая смертность, $F_{4}$ - уровень развития социальной инфраструктуры;

$$
y_{10}=7,4-0,5 F_{4},
$$

где $y_{10}$ - перинатальная смертность, $F_{4}$ - уровень развития социальной инфраструктуры;

$$
y_{12}=50,09-10,47 F_{2},
$$

где $y_{12}$ - стандартизированный показатель смертности населения от болезней органов дыхания, $F_{2}$ - условия быта населения;

$$
y_{15}=22,07+2,01 F_{1}-3,5 F_{2}-3,7 F_{4},
$$

где $y_{15}$ - стандартизированный показатель смертности населения от инфекционных и паразитарных болезней, $F_{1}$ - уровень социальноэкономического развития территории, $F_{2}-$ условия быта населения, $F_{4}-$ уровень развития социальной инфраструктуры; 
Социально-экономические факторы риска здоровью населения субъектов РФ, выделенные по результатам факторного анализа

\begin{tabular}{|c|c|c|c|c|}
\hline & Параметр & Показатели с нагрузкой свыше 0,7 & 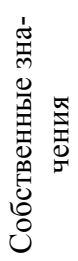 & 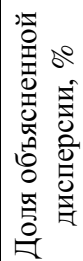 \\
\hline \multirow{9}{*}{$F_{1}$} & \multirow{9}{*}{$\begin{array}{l}\text { Уровень соци- } \\
\text { ально-экономи- } \\
\text { ческого разви- } \\
\text { тия территории }\end{array}$} & Величина прожиточного минимума, установленного на территории (руб.) & \multirow{9}{*}{8,53} & \multirow{9}{*}{34,1} \\
\hline & & Среднедушевые денежные доходы населения (руб.) & & \\
\hline & & Стоимость минимального набора продуктов питания (руб.) & & \\
\hline & & Фактическое конечное потребление домашних хозяйств (тыс. руб. на душу населения) & & \\
\hline & & Валовой региональный продукт (валовая добавленная стоимость) на душу населения (руб.) & & \\
\hline & & $\begin{array}{l}\text { Среднемесячная номинальная начисленная заработная плата работников организа- } \\
\text { ций (руб.) }\end{array}$ & & \\
\hline & & Стоимость основных фондов (руб.) & & \\
\hline & & Инвестиции в основной капитал (руб.) на душу населения & & \\
\hline & & Располагаемые ресурсы домохозяйств (руб.) & & \\
\hline \multirow{3}{*}{$F_{2}$} & \multirow{3}{*}{$\begin{array}{c}\text { Условия быта } \\
\text { населения }\end{array}$} & Удельный вес общей площади, оборудованной водопроводом (\%) & \multirow{3}{*}{4,32} & \multirow{3}{*}{17,2} \\
\hline & & Удельный вес общей площади, оборудованной водоотведением (канализацией) (\%) & & \\
\hline & & Удельный вес общей площади, оборудованной отоплением (\%) & & \\
\hline \multirow{5}{*}{$F_{3}$} & \multirow{5}{*}{$\begin{array}{c}\text { Состояние сис- } \\
\text { темы здраво- } \\
\text { охранения }\end{array}$} & Число больничных коек (на 1000 человек) & \multirow{5}{*}{2,1} & \multirow{5}{*}{8,7} \\
\hline & & $\begin{array}{l}\text { Мощность врачебных амбулаторно-поликлинических учреждений (посещений } \\
\text { в смену, тыс.) }\end{array}$ & & \\
\hline & & Количество врачей всех специальностей (на 1000 человек) & & \\
\hline & & Количество среднего медперсонала (на 1000 человек) & & \\
\hline & & Расходы на здравоохранение (руб./чел.) & & \\
\hline \multirow[b]{2}{*}{$F_{4}$} & \multirow{2}{*}{$\begin{array}{c}\text { Уровень разви- } \\
\text { тия социальной } \\
\text { инфраструкту- } \\
\text { ры }\end{array}$} & Общая площадь жилых помещений, приходящаяся в среднем на одного жителя (м²) & \multirow[b]{2}{*}{1,5} & \multirow[b]{2}{*}{6,2} \\
\hline & & $\begin{array}{l}\text { Охват детей дошкольными образовательными учреждениями (\% от численности } \\
\text { детей соответствующего возраста) }\end{array}$ & & \\
\hline
\end{tabular}

$$
y_{17}=21,6-3,12 F_{2},
$$

где $y_{17}-$ стандартизированный показатель смертности населения от транспортных несчастных случаев, $F_{2}$ - условия быта населения;

$$
y_{19}=354,07-55,16 F_{3}-57,11 F_{4},
$$

где $y_{19}$ - заболеваемость болезнями желчного пузыря и желчевыводящих путей, $F_{3}$ - состояние системы здравоохранения, $F_{4}-$ уровень развития социальной инфраструктуры;

$$
y_{24}=1698,9-275,1 F_{3}-229,07 F_{4},
$$

где $y_{24}-$ заболеваемость болезнями нервной системы, $F_{3}$ - состояние системы здравоохранения, $F_{4}-$ уровень развития социальной инфраструктуры;

$$
y_{27}=55,0-10,20 F_{4},
$$

где $y_{27}-$ заболеваемость болезнями печени, $F_{4}-$ уровень развития социальной инфраструктуры;

$$
y_{29}=2880,89-366,22 F_{3},
$$

где $y_{29}$ - заболеваемость болезнями системы кровообращения, $F_{3}$ - состояние системы здравоохранения;

$$
y_{32}=673,36-123,24 F_{3},
$$

где $y_{32}-$ заболеваемость болезнями, характеризующимися повышенным кровяным давлением, $F_{3}$ - состояние системы здравоохранения.

Для определения в наибольшей степени зависимых от данных факторов показателей здоровья все они ранжировались по критерию $R^{2}$. Для моделей, описанных выше в виде математических уравнений, ранжирование выглядело следующим образом: 1) стандартизированный показатель смертности населения от болезней органов дыхания $\left(R^{2}=0,33\right)$; 2) младенческая смертность $\left(R^{2}=0,23\right)$; 3) заболеваемость болезнями нервной системы $\left(R^{2}=0,23\right)$; 4$)$ смертность населения от транспортных несчастных случаев 
$\left.\left(R^{2}=0,22\right) ; 5\right)$ заболеваемость болезнями желчного пузыря и желчевыводящих путей $\left(R^{2}=0,21\right)$; 6) стандартизированный показатель смертности населения от инфекционных и паразитарных болезней $\left.\left(R^{2}=0,16\right) ; 7\right)$ заболеваемость болезнями печени $\left(R^{2}=0,11\right)$; 8) заболеваемость болезнями системы кровообращения $\left(R^{2}=0,09\right)$; 9) перинатальная смертность $\left.\left(R^{2}=0,08\right) ; 10\right)$ заболеваемость болезнями, характеризующимися повышенным кровяным давлением $\left(R^{2}=0,06\right)$.

Для моделей, включающих несколько факторов, были рассчитаны частные коэффициенты детерминации для определения долевого вклада вариации отдельных социально-экономических факторов в вариацию показателя здоровья. На основе данных коэффициентов все факторы, вошедшие в модель, были ранжированы.

Установлено, что в детерминации стандартизированного показателя смертности населения от инфекционных и паразитарных болезней приоритетную роль играет уровень развития социальной инфраструктуры, затем условия быта населения и уровень социально-экономического развития территории: воздействие на заболеваемость болезнями желчного пузыря и желчевыводящих путей уровня развития социальной инфраструктуры больше, чем состояния системы здравоохранения, тогда как заболеваемость болезнями нервной системы, напротив, сильнее зависит от состояние системы здравоохранения, нежели от уровня развития социальной инфраструктуры в регионе.

Отправной точкой для реализации процедуры характеристики риска являлось определение пороговых значений влияния макросоциальных факторов на показатели здоровья. В качестве порогового устанавливалось значение, соответствующее наиболее высокому каждого из комплексных факторов $\left(F_{1}-F_{4}\right)$ : для фактора «уровень социально-экономического развития территории» $\left(F_{1}\right)$ пороговое значение составило 3,998, для фактора «условия быта населения» $\left(F_{2}\right)-2,431$, для фактора «состояние системы здравоохранения» $\left(F_{3}\right)-3,100$, для фактора «уровень развития социальной инфраструктуры» $\left(F_{4}\right)-1,687$.

Высокий уровень риска, связанного с воздействием социально-экономических факторов, установлен в отношении показателя «младенческая смертность» в 8 регионах (табл. 2).

Как видно из табл. 2, в Республике Дагестан $(R=0,00225)$, Еврейской автономной области $(R=0,00194)$, Республике Тыва $(R=0,0018)$, Республике Ингушетия $(R=0,00174)$, Республике Алтай $(R=0,00126)$, Амурской области $(R=$ $=0,001192)$, Хабаровском крае $(R=0,001146)$, Камчатском крае $(R=0,001031)$ требуются незамедлительные действия по снижению социально детерминированного риска младенческой смертности, направленные, в первую очередь, на развитие социальной инфраструктуры на территориях.

Еще в 43 регионах уровень риска, связанного с воздействием социально-экономических факторов на формирование младенческой смертности, является средним, что, однако, также недопустимо для населения в целом. Значения риска среди регионов данной группы варьируются от 0,00962 в Приморском крае до 0,00011 во Владимирской области.

Средний уровень риска (значение риска превышает $1 \cdot 10^{-4}$, что недопустимо для населения в целом), ассоциированного с воздействием социально-экономических факторов, установлен в отношении показателя «стандартизированный показатель смертности населения от болезней органов дыхания» в следующих регионах: Республика Дагестан $(R=0,000263)$, Республика Тыва $(R=0,000251)$, Республика Марий Эл $(R=0,000231)$, Республика Чувашия $(R=0,000209)$, Республика Алтай $(R=0,000209)$,

Таблица 2

Параметры расчета риска младенческой смертности, ассоциированного с социально-экономическими факторами, в регионах РФ

\begin{tabular}{|c|c|c|c|c|c|c|c|}
\hline Регион & $\begin{array}{c}\text { Значение, } \\
\% о\end{array}$ & $\begin{array}{c}\text { Пороговое } \\
\text { значение, \%o }\end{array}$ & $\begin{array}{l}\text { Дополнитель- } \\
\text { ные случаи, \%o }\end{array}$ & $\begin{array}{c}\text { Вероятность } \\
(P)\end{array}$ & Тяжесть & $R^{2}$ & $\begin{array}{c}\text { Риск } \\
(R)\end{array}$ \\
\hline Республика Дагестан & 15,3 & 5,51 & 9,78 & 0,0097 & 1 & 0,23 & 0,00225 \\
\hline Еврейская автономная область & 14,1 & 5,51 & 8,58 & 0,0085 & 1 & 0,23 & 0,00197 \\
\hline Республика Тыва & 13,5 & 5,51 & 7,98 & 0,0079 & 1 & 0,23 & 0,00183 \\
\hline Республика Ингушетия & 13,1 & 5,51 & 7,58 & 0,0075 & 1 & 0,23 & 0,00174 \\
\hline Республика Алтай & 11 & 5,51 & 5,48 & 0,0054 & 1 & 0,23 & 0,00126 \\
\hline Амурская область & 10,7 & 5,51 & 5,18 & 0,0051 & 1 & 0,23 & 0,00119 \\
\hline Хабаровский край & 10,5 & 5,51 & 4,98 & 0,0049 & 1 & 0,23 & 0,00114 \\
\hline Камчатский край & 10 & 5,51 & 4,48 & 0,0044 & 1 & 0,23 & 0,00103 \\
\hline
\end{tabular}


Республика Бурятия $(R=0,000192)$, Иркутская область $(R=0,000167), \quad$ Амурская область $(R=0,000146)$, Ивановская область $(R=0,000145)$, Красноярский край $(R=0,000138)$, Кемеровская область $(R=0,000136)$, Магаданская область $(R=0,000135)$, Приморский край $(R=0,000126)$, Сахалинская область $(R=0,000124)$, Курская область $(R=0,000123)$, Кировская область $(R=0,000119)$, Алтайский край $(R=0,000118)$, Псковская область $(R=0,000108)$, Республика Башкортостан $(R=0,000107)$, Челябинская область $(R=0,000105)$, Курганская область $(R=0,000104)$, Смоленская область $(R=0,000104)$, Хабаровский край $(R=0,000103)$.

В отношении показателя «перинатальная смертность» средний уровень риска, не допустимый для населения в целом, установлен в 24 регионах РФ: Республика Ингушетия $(R=0,000595)$, Брянская область $(R=0,000339)$, Республика Дагестан $(R=0,000323)$, Амурская область $(R=0,000315)$, Камчатский и Хабаровский края (в обоих $R=0,000291)$, Вологодская область $(R=0,000267)$, Астраханская область $(R=0,000243)$, Псковская область $(R=0,000235)$, Рязанская и Тверская области (в обеих $R=0,000227)$, Приморский край $(R=0,000219)$, Нижегородская область $(R=0,000203)$, Волгоградская область и Ставропольский край (в обоих регионах $R=0,000195)$, Республика Алтай $(R=0,000187)$, Оренбургская и Курганская области (в обеих $R=0,000179)$, Республика Северная ОсетияАлания $(R=0,000163)$, Новгородская область и Еврейская автономная область (в обеих $R=0,000147)$, Магаданская область $(R=0,000139)$, Ульяновская область и Республика Саха (Якутия) (в обоих субъектах $R=0,000123$ ).

Социально детерминированный риск в отношении стандартизированного показателя смертности населения от инфекционных и паразитарных болезней превышает допустимый уровень только в одном субъекте РФ - Республике Тыва $(R=0,000110)$, а по показателю «заболеваемость болезнями системы кровообращения»- в 6 регионах: Республика Ингушетия $(R=0,000223)$, Московская область $(R=0,000199)$, Ленинградская область $(R=0,000193)$, Алтайский край $(R=0,000128)$, Камчатский край $(R=0,000103)$ и Белгородская область $(R=0,000102)$.

По показателям «заболеваемость болезнями, характеризующимися повышенным кровяным давлением», «заболеваемость болезнями печени», «заболеваемость болезнями желчного пузыря и желчевыводящих путей», «смертность населения от транспортных несчастных случа- ев» и «заболеваемость болезнями нервной системы» ни в одном из субъектов РФ не обнаружено превышений допустимого уровня.

Выводы. Оценка риска здоровью, связанного с социально-экономическими факторами, на основе предложенной методики позволила установить высокий уровень риска в отношении показателя «младенческая смертность» в 8 регионах, «заболеваемость болезнями системы кровообращения»- в 6 регионах, а в отношении показателя «смертность населения от инфекционных и паразитарных заболеваний»в одном регионе РФ. В данных субъектах Федерации требуются экстренные действия по снижению социально детерминированного риска. В ряде регионов риск находится на среднем уровне, что определяет необходимость оперативных мероприятий по его снижению.

Ситуация в регионах Дальневосточного федерального округа может быть охарактеризована как напряженная. Так, в Приморском, Хабаровском и Камчатском краях, а также Магаданской и Амурской областях допустимый уровень риска превышен по 3 показателям здоровья, в Республике Саха (Якутия), Еврейской автономной области - по 2, и только в Сахалинской области по 1. Таким образом, среди всех субъектов РФ, входящих в состав округа ${ }^{1}$, нет ни одного, где бы социально-экономические факторы не формировали повышенный уровень риска популяционного здоровья.

Для сравнения, среди 18 регионов, входящих в Центральный федеральный округ, превышение допустимого уровня риска по 3 показателям здоровья не встречается ни разу, а в г. Москве, Тамбовской, Тульской и Ярославской областях уровень социально детерминированного риска по всем показателям находится в границах допустимого.

В таких субъектах РФ, как Республика Дагестан, Республика Тыва и Алтайский край, наблюдается недопустимый уровень риска, связанного с действием социально-экономических факторов, по 3 показателям, 2 из которых - это «стандартизированный показатель смертности населения от болезней органов дыхания» и «младенческая смертность». Третьим показателям является: в Республике Тыва - стандартизированный показатель смертности от инфекционных и паразитарных болезней (кроме того, значение риска по показателю «смерт-

\footnotetext{
${ }^{1} \mathrm{~B}$ анализ не был включен Чукотский АО из-за от-
} сутствия статистических данных по ряду показателей. 
ность населения от транспортных несчастных случаев», составляющее для региона 0,000098, близко к неприемлемому), в Республике Дагестан - перинатальная смертность, а в Алтайском крае - заболеваемость болезнями системы кровообращения.

Полученные результаты позволяют рекомендовать органам исполнительной власти субъектов Федерации при формировании региональных планов действий использовать в качестве информационной основы результаты оценки социально детерминированных рисков, полученные как в целом для Российской Федерации, так и для конкретного региона. Вклю- чить показатели рисков для здоровья в систему критериев оценки эффективности деятельности отдельных структурных подразделений и органов местного самоуправления и, соответственно, в систему социально-экономического мониторинга. Использовать методологию оценки рисков для здоровья и накопленные данные о взаимосвязях «фактор - эффект», включая математические модели разного вида, при ситуационном моделировании. Принять за практику ежегодное выполнение оценок экономических потерь от смертности, инвалидизации и заболеваемости населения, связанных с социально-экономическими факторами.

\section{Список литературы}

1. Зайцева Н.В., Май И.В., Шур П.З. Анализ риска здоровью. населения на современном этапе // Здравоохранение Российской Федерации. - 2013. - № 2. - С. 20-24.

2. Захаренков В.В., Виблая И.В. Негативные связи показателей здоровья населения с уровнем безработицы в г. Новокузнецке // Бюлл. ВСНЦ СО РАМН. - 2010. - № 4. - С. 169-172.

3. Иванова Е.И. Смертность российских мужчин (причины и региональные различия) // Социологические исследования. - 2010. - № 5. - С. 87-99.

4. Использование регрессионных моделей в системе поддержки принятия решений по управлению риском для здоровья населения в результате воздействия социально-экономических факторов / В.Б. Гурвич, Б.И. Никонов, О.Л. Малых, Н.И. Кочнева, А.Н. Вараксин, Т.А. Маслакова, С.В. Кузьмин, Е.А. Кузьмина, С.В. Ярушин // Гигиена и эпидемиология. - 2008. - № 8 (48). - С. 26-33.

5. Костылева Л.В., Дубничев Р.В. Неравенство населения и его влияние на социально-экономическое развитие региона // Экономические и социальные перемены: факты, тенденции, прогноз. - 2009. - № 4. C. $95-103$.

6. Медико-социальные факторы риска и предупреждение смертности трудоспособного населения / О.Е. Коновалов, Д.И. Кича, Н.А. Тяжлов, О.А. Меркулов // Вестн. МСИ. - 2008. - № 3. - С. $45-48$.

7. Онищенко Г.Г. Оценка и управление рисками для здоровья как эффективный инструмент решения задач обеспечения санитарно-эпидемиологического благополучия населения Российской Федерации // Анализ риска здоровью. - 2013. - № 1. - С. 4-14.

8. Определение влияния социо-, эколого-экономических факторов на смертность от новообразований / Г.С. Розенберг, Н.Г. Лифиренко, Н.В. Костина, Д.В. Лифиренко // Известия Самарского научн. центра Рос. академ. наук. - 2009. - № 11 (1). - С. 1182-1185.

9. Оценка влияния социально-экономических факторов на медико-демографические показатели / М.И. Чубирко, Н.М. Пичужкина, Л.А. Масайлова, Г.В. Ласточкина // Гигиена и санитария. - 2012. - № 6. - С. $36-38$.

\section{References}

1. Zaitseva N.V., May I.V., Shur P.Z. Analiz riska zdorov'ju. naselenija na sovremennom jetape [Public health risk analysis at the modern stage]. Zdravoohranenie Rossijskoj Federacii, 2013, no. 2, pp. 20-24.

5. Zaharenkov V.V., Viblaya I.V. Negativnye svjazi pokazatelej zdorov'ja naselenija s urovnem bezraboticy $\mathrm{v}$ g. Novokuznecke [Negative relationships between the population health indicators and the level of unemployment in Novokuznetsk]. Bjull. VSNC SO RAMN, 2010, no. 4, pp. 169-172.

3. Ivanova E.I. Smertnost' rossijskih muzhchin (prichiny i regional'nye razlichija) [Mortality of men in Russia (reasons and regional differences) ]. Sociologicheskie issledovanija, 2010, no. 5, pp. 87-99.

2. Gurvich V.B., Nikonov B.I., Malyh O.L., Kochneva N.I., Varaksin A.N., Maslakova T.A., Kuz'min S.V., Kuz'mina E.A., Jarushin S.V. Ispol'zovanie regressionnyh modelej v sisteme podderzhki prinjatija reshenij po upravleniju riskom dlja zdorov'ja naselenija v rezul'tate vozdejstvija social'no-jekonomicheskih faktorov [Use of regression models in the system for supporting the making of decisions on the public health risk management as a result of impact of social and economic factors]. Gigiena i jepidemiologija, 2008, no. 8 (48), pp. 26-33.

6. Kostyleva L.V., Dubnichev R.V. Neravenstvo naselenija i ego vlijanie na social'no-jekonomicheskoe razvitie regiona [Inequality of population and its impact on the social and economic development of region]. Jekonomicheskie i social'nye peremeny: fakty, tendencii, prognoz, 2009, no. 4, pp. 95-103. 
4. Konovalov O.E., Kicha D.I., Tjazhlov N.A., Merkulov O.A. Mediko-social'nye faktory riska i preduprezhdenie smertnosti trudosposobnogo naselenija [Medical and social risk factors and prevention of mortality for the working population]. Vest. MSI, 2008, no. 3, pp. 45-48.

9. Onishhenko G.G. Ocenka i upravlenie riskami dlja zdorov'ja kak jeffektivnyj instrument reshenija zadach obespechenija sanitarno-jepidemiologicheskogo blagopoluchija naselenija Rossijskoj Federacii [Assessment and management of health risks as the effective tool for solving the tasks on ensuring the sanitary and epidemiological welfare of population in the Russian Federation]. Analiz riska zdorov'ju, 2013, no. 1, pp. 4-14.

7. Rozenberg G.S., Lifirenko N.G., Kostina N.V., Lifirenko D.V. Opredelenie vlijanija socio-jekologojekonomicheskih faktorov na smertnost' ot novoobrazovanij [Determining the impact of social, ecological and economic factors on the mortality from neoplasms]. Izvestija Samarskogo nauchn. centra Ros. akadem. nauk, 2009, vol. 11, no. 1, pp. 1182-1185.

1. Chubirko M.I., Pichuzhkina N.M., Masaylova L.A., Lastochkina G.V. Ocenka vlijanija social'nojekonomicheskih faktorov na mediko-demograficheskie pokazateli [Assessing the impact of social and economic factors on the medical and demographic indicators]. Gigiena i sanitarija, 2012, no. 6, pp. 36-38.

\section{METHODICAL APPROACHES AND PRACTICE OF THE ASSESSMENT OF RISK ASSOCIATED WITH IMPACT OF SOCIAL AND ECONOMIC FACTORS ON THE POPULATION HEALTH IN THE REGIONS OF RUSSIA}

\section{N.A. Lebedeva-Nesevrya, M.Yu. Tsinker}

FBIS “Federal Scientific Center of Medical-Preventive Health Risk Management Technologies”, Russian Federation, Perm, 82 Monastyrskaya St., 614045

The article proposes the algorithm and methods for assessing the risks of the population health deterioration associated with impact of social and economic factors at the macro level. The methods are tested on the materials under 78 entities of the Russian Federation for 2010-2013. The high level of risk in relation to indicators "infant mortality", "morbidity with the blood circulatory system diseases" and "mortality of population from infectious and parasitic diseases" is established in a number of regions of the Russian Federation. It is demonstrated that the socially determined health risk in the most entities of the Russian Federation is at medium level that determines the need for operative measures on its mitigation.

Key words: social and economic factors, risk, public health.

(C) Lebedeva-Nesevrya N.A., Tsinker M.Yu., 2015

Lebedeva-Nesevrya Nataliya Aleksandrovna - Doctor of sociological sciences, Head of social risk analysis laboratory (e-mail: natnes@fcrisk.ru, tel.8 (342) 237-25-47).

Tsinker Mikhail Yurievich - junior research associate of Department of Mathematical Modeling of Systems and Processes (e-mail: cinker@fcrisk.ru; tel. 8 (342) 237-18-04). 


\title{
ПРАКТИКА ОЦЕНКИ РИСКА В ГИГИЕНИЧЕСКИХ И ЭПИДЕМИОЛОГИЧЕСКИХ ИССЛЕДОВАНИЯХ
}

УДК 613.955

\section{ВЛИЯНИЕ УСЛОВИЙ ОБРАЗОВАТЕЛЬНОЙ СРЕДЫ НА СОСТОЯНИЕ ЗДОРОВЬЯ ДЕТЕЙ ДОШКОЛЬНОГО И ШКОЛЬНОГО ВОЗРАСТА НА ТЕРРИТОРИИ АРХАНГЕЛЬСКОЙ ОБЛАСТИ}

\author{
Р.В. Бузинов ${ }^{1}$, Е.А. Аверина ${ }^{2}$, Т.Н. Унгуряну ${ }^{1}$ \\ ${ }^{1}$ Управление Федеральной службы по надзору в сфере защиты прав потребителей и благополучия человека \\ по Архангельской области, Россия, 163000, г. Архангельск, ул. Гайдара, 24 \\ ${ }^{2}$ ФБУЗ «Центр гигиены и эпидемиологии в Архангельской области», \\ Россия, 163001, г. Архангельск, пр. Троицкий, 164, корп. 1
}

Выполнено описательное эпидемиологическое исследование по изучению распространенности «школьной» патологии у детского населения и влиянию на нее условий образовательной среды в дошкольных и школьных учреждениях на территории Архангельской области. Установлено, что основныли нарушениями здоровья, обнаруженными при профилактических медицинских осмотрах детей и подростков-школьников, являются нарушение осанки, сколиоз и нарушение остроты зрения. Наибольшая частота нарушений осанки зафиксирована у детей при переходе к предметному обучению, интенсивность сколиоза и нарушение остроты зрения-в возрасте 15 лет. Выявлены ассоциации замеров между уровнями освещенности, не соответствующими гигиеническим нормативам, и частотой сколиоза у детей перед поступлением в школу $\left(r_{s}=0,472 ; p=0,048\right) ;$ замерами мебели, не отвечающими санитарным требованиям, в компьютерных классах школ и нарушением остроты зрения у детей в 10-11 лет $\left(r_{s}=0,529\right.$; p=0,024); а также между замерами мебели, не соответствующими санитарным требованиям, в детских дошкольных учреждениях и нарушением осанки у детей за год до поступления и непосредственно перед поступлением в школу $\left(r_{s}=0,601 ; p=0,008\right.$ и $r_{s}=0,90 ; p=0,037$ соответственно $)$.

Ключевые слова: дети дошкольного и школьного возраста, медицинские осмотры, нарушение осанки, нарушение остроты зрения, образовательная среда, освещенность, школьная мебель.

Здоровье детей, их рост и развитие, социально-психологическая адаптация во многом определяются средой, в которой они находятся [3]. В настоящее время широко распространены такие понятия, как «болезни цивилизации», «школьный стресс», «школьная патология» [2, 10]. Напряженность процессов роста и развития, определяющих функционирование детского организма, одновременно делает его и наиболее уязвимым, чувствительным к неблагоприятным воздействиям [6]: время обучения в детском саду и школе совпадает с периодом интенсивного роста и развития ребенка, когда организм наиболее чувствителен к воздействию неблагоприятных условий окружающей среды.
Школьная образовательная среда, в которой проводит ребенок более $70 \%$ активного времени жизни, содержит факторы риска нарушений здоровья и тем самым осложняет работу механизмов саморегуляции физиологических функций, способствует развитию заболеваний.

В течение всего периода обучения на здоровье учащихся влияет модернизация системы образования [15]. Интенсификация обучения в школе еще более усугубила состояние здоровья детей. Согласно результатам исследований отечественных ученых, ведущими среди причин, неблагоприятно влияющих на состояние здоровья школьников, являются: недостаточная двигательная активность, чрезмерная учебная на-

(C) Бузинов Р.В., Аверина Е.А., Унгуряну Т.Н., 2015

Бузинов Роман Вячеславович - доктор медицинских наук, руководитель (e-mail: arkh@29.rospotrebnadzor.ru; тел. +7 (8182) 20-05-69).

Аверина Екатерина Андреевна - врач (e-mail: averina-e.a@mail.ru; тел. 7 (8182) 27-64-83).

Унгуряну Татьяна Николаевна - доктор медицинских наук, главный специалист-эксперт (e-mail: unguryanu_tn@mail.ru; тел. 7 (8182) 21-04-61). 
грузка, неправильное питание, несоответствие мебели росту и возрасту и недостаточная освещённость помещения, а также отсутствие знаний о здоровом образе жизни у детей, педагогов и родителей, недостаточная деятельность школы по формированию культуры здоровья.

Многие авторы отмечают рост числа детей с проявлениями «школьной» патологии [8, 11-13, 18. Многочисленные медико-гигиенические и психофизиологические исследования, результаты всероссийских диспансеризаций, отчеты призывных комиссий свидетельствуют о неудовлетворительном состоянии здоровья подрастающего поколения $[1,4,5,7,9,11,16]$.

В литературе приводятся такие понятия, как «школьная близорукость», «школьные сколиозы» и даже «эпидемиии» школьных форм патологии $[14,17]$. Вместе с тем в исследованиях недостаточно представлены данные динамического наблюдения по выявляемости наиболее значимой «школьной» патологии на различных этапах обучения.

Целью настоящего исследования было изучение распространенности нарушения остроты зрения, осанки, сколиоза у детей дошкольного и школьного возраста на территории Архангельской области и оценка влияния образовательной среды на проявление данных патологий.

Выполнено описательное эпидемиологическое исследование по изучению распространенности «школьной» патологии у детского населения и условий образовательной среды в дошкольных и школьных учреждениях в городах и районах Архангельской области. Здоровье детей и подростков изучено по форме федерального статистического наблюдения № 31 «Сведения о медицинской помощи детям и подросткам-школьникам» за 2008-2013 гг. в следующих возрастных группах: до 14 лет включительно; перед поступлением в детское дошкольное учреждение; за год до поступления в школу; перед поступлением в школу; в конце 1-го года обучения; при переходе к предметному обучению (4-5-й классы); в возрасте 15 лет включительно и перед окончанием школы (16-17 лет включительно).

Замеры мебели и уровней освещенности в общеобразовательных и дошкольных организациях проанализированы по форме федерального статистического наблюдения № 9-06 «Сведения о санитарно-эпидемиологическом состоянии учреждений для детей и подростков» за 2008-2013 гг. относительно городов и районов Архангельской области.
Для описания показателей здоровья использовался уровень (на 1000 детей соответствующей группы) и структура патологической пораженности, а гигиенические условия образовательной среды оценивались по удельному весу проведенных замеров, не соответствующих гигиеническим нормативам.

Сравнение качественных признаков проводилось с помощью критерия хи-квадрат $\left(\chi^{2}\right)$. Для проверки влияния условий образовательной среды на нарушения здоровья детей использовался коэффициент корреляции рангов Спирмена $\left(r_{s}\right)$. Критический уровень значимости при проверке нулевых гипотез принимался равным 0,05. Статистический анализ данных выполнен с помощью программного обеспечения Stata 12.0 и Epi Info 3.4.1.

За период с 2008 по 2013 г. в городах и районах Архангельской области проведено 75,6 тысячи замеров уровней освещенности в учреждениях школьного и дошкольного образования. Наибольшее количество выполненных замеров (67\%) приходится на города Архангельской области. Удельный вес нестандартных замеров уровней освещенности в детских дошкольных учреждений городов и районов Архангельской области был одинаков и составил $13,6$ и $14,0 \%$ соответственно $(p=0,474)$ (табл. 1$)$. Самый высокий удельный вес замеров, не отвечающих санитарным требованиям, установлен в Коношском (32\%), Холмогорском $(40 \%)$ и Лешуконском (54\%) районах. Среди городов Архангельской области наибольшее несоответствие гигиенических параметров уровней освещенности установлено в учреждениях дошкольного образования городов Северодвинска $(20,0 \%)$ и Коряжмы $(13,8 \%)$, где каждый шестой замер освещенности не соответствует санитарным нормативам.

В районах Архангельской области удельный вес замеров освещенности в образовательных учреждениях, не соответствующей гигиеническим нормативам $(16,6 \%)$, был статистически значимо выше $(p<0,001)$ по сравнению с городами $(12,9 \%)$ на $3,7 \%$. Удельный вес замеров уровней освещенности оказался самым высоким в Красноборском (17,4\%), Вельском $(18,2 \%)$, Виноградовском $(20,8 \%)$, Верхнетоемском $(28,3 \%)$ и Мезенском $(31,2 \%)$ районах. В Коношском $(50,1 \%)$ и в Холмогорском $(62,3 \%)$ районах каждое второе измерение освещенности не соответствует санитарным нормативам. Среди городов Архангельской области наибольшие несоответствия параметров 
Т аблиц а 1

Основные гигиенические параметры образовательных учреждений в городах и районах Архангельской области за 2008-2013 гг.

\begin{tabular}{|c|c|c|c|c|c|c|c|c|c|c|c|}
\hline \multirow{3}{*}{ Показатель } & \multicolumn{3}{|c|}{ Города } & \multicolumn{3}{|c|}{ Районы } & \multicolumn{3}{|c|}{ Все территории } & \multirow{3}{*}{$\chi^{2}$} & \multirow{3}{*}{$p$} \\
\hline & \multirow{2}{*}{$\begin{array}{c}\text { Всего } \\
\text { замеров, } \\
\text { абс. } \\
\text { число }\end{array}$} & \multicolumn{2}{|c|}{$\begin{array}{c}\text { из них } \\
\text { не соответствует } \\
\text { гигиеническим } \\
\text { нормативам }\end{array}$} & \multirow[t]{2}{*}{$\begin{array}{c}\text { Всего } \\
\text { замеров, } \\
\text { абс.число }\end{array}$} & \multicolumn{2}{|c|}{$\begin{array}{c}\text { из них } \\
\text { не соответствует } \\
\text { гигиеническим } \\
\text { нормативам }\end{array}$} & \multirow[t]{2}{*}{$\begin{array}{c}\text { Всего } \\
\text { замеров, } \\
\text { абс.число }\end{array}$} & \multicolumn{2}{|c|}{$\begin{array}{c}\text { из них } \\
\text { не соответствует } \\
\text { гигиеническим } \\
\text { нормативам }\end{array}$} & & \\
\hline & & \begin{tabular}{|l|} 
абс. \\
число
\end{tabular} & $\begin{array}{c}\text { удельный } \\
\text { вес, \% }\end{array}$ & & $\begin{array}{l}\text { абс. } \\
\text { число }\end{array}$ & $\begin{array}{c}\text { удельный } \\
\text { вес, \% }\end{array}$ & & $\begin{array}{l}\text { абс. } \\
\text { число }\end{array}$ & $\begin{array}{c}\text { удельный } \\
\text { вес, \% }\end{array}$ & & \\
\hline \multicolumn{12}{|c|}{ Детские дошкольные учрежсдения } \\
\hline Замеры мебели & 6757 & 316 & 4,6 & 3742 & 307 & 8,2 & 10499 & 623 & 5,9 & 53,6 & $<0,001$ \\
\hline Уровень освещенности & 12268 & 1666 & 13,6 & 6303 & 880 & 14,0 & 18571 & 2546 & 13,7 & 0,51 & 0,474 \\
\hline \multicolumn{12}{|c|}{ Общеобразовательные учреждения } \\
\hline Замеры мебели & 4454 & 442 & 9,9 & 4562 & 753 & 16,5 & 9016 & 1195 & 13,3 & 84,9 & $<0,001$ \\
\hline $\begin{array}{l}\text { Замеры мебели в ком- } \\
\text { пьютерном классе }\end{array}$ & 128 & 24 & 18,8 & 213 & 48 & 22,5 & 341 & 72 & 21,1 & 0,69 & 0,406 \\
\hline Уровень освещенности & 38354 & 4944 & 12,9 & 18665 & 3095 & 16,6 & 57019 & 8039 & 14,1 & 141,2 & $<0,001$ \\
\hline
\end{tabular}

освещенности установлены в г. Новодвинске (22\%), где каждое пятое обследование в общеобразовательных школах не соответствует гигиеническим требованиям.

Всего за изученный период проведено 10,5 тысячи замеров мебели в детских дошкольных учреждениях. Наибольшее количество $(64,4 \%)$ выполненных замеров приходится на города Архангельской области. Количество проведенных исследований мебели в общеобразовательных школах составило 4,5 тысячи. Удельный вес замеров мебели, не отвечающих санитарным требованиям, в образовательных учреждениях районов в 2 раза больше, чем в городах Архангельской области, что составляет $16,5 \%$ в общеобразовательных школах и $8,2 \%$ в дошкольных учреждениях $(p<0,001)$ (см. табл. 1$)$.

Набольший удельный вес замеров мебели, не соответствующих гигиеническим требованиям: в детских дошкольных учреждениях был установлен в Коношском (20,3\%), Онежском $(20,8 \%)$, Устьянском $(21,0 \%)$ и Шенкурском $(25,7 \%)$ районах, где каждое пятое обследование не отвечало санитарным нормативам; в общеобразовательных школах - в Коношском $(21,0 \%)$, Виноградовском $(18,9 \%)$, Ленском $(30,3 \%)$, Вилегодском $(30,6 \%)$, Холмогорском $(57,8 \%)$, Вельском (64,0\%), Верхнетоемском $(68,0 \%)$, Онежском $(76,9 \%)$ и Шенкурском $(80,0 \%)$ районах.

В общеобразовательных школах Архангельской области проведен 341 замер параметров рабочего места пользователя ПЭВМ за исследуемый период, из них $63 \%$ осуществлено в районах Архангельской области. Удельный вес замеров, не отвечающих санитарным требованиям, составляет $22,5 \%$ - в районах и $18,8 \%$ в городах $(p=0,406)$. Удельный вес нестандартных замеров был выше в Верхнетоемском $(26,7 \%), \quad$ Вельском $(45,8 \%)$, Приморском $(71,4 \%)$ и Коношском $(86,7 \%)$ районах. Среди городов Архангельской области наибольшее несоответствие параметров рабочего места пользователя ПЭВМ в компьютерных классах установлено в городах Архангельске $(26,0 \%)$ и Новодвинске (33,3\%), где каждое третье обследование не соответствует санитарным нормативам.

По данным периодических медицинских осмотров нарушение осанки и остроты зрения является основными патологиями у детей дошкольного и школьного возраста. В структуре распространенности «школьных» патологий удельный вес данных нарушений оставил 39 и $35 \%$ соответственно. Среднегодовая частота выявления нарушения осанки, остроты зрения и сколиоза у детей до 17 лет включительно в целом по Архангельской области за исследуемый 6-летний период составила 138,$3 ; 123$ и $27,5 \%$ о соответственно.

Изучение распространенности нарушений осанки по периодам дошкольного и школьного образования показало последовательное нарастание частоты данной патологии в группах детей от поступления в детское дошкольное учреждение до перехода к предметному обучению (4-5-е классы), где выявлены максимальные уровни данной патологии $(274,6 \%)$. Около $15 \%$ детей перед поступлением в школу уже имеют нарушения осанки. В возрасте 15 лет и перед окончанием школы уровни нарушения осанки составили 240,8 и $159,5 \%$ соответственно, что 
Среднегодовая частота выявления нарушений осанки, остроты зрения и сколиоза в различных возрастных группах детей в городах и районах Архангельской области за 2008-2013 гг.

\begin{tabular}{|c|c|c|c|c|c|c|}
\hline \multirow[t]{2}{*}{ Группа } & \multicolumn{2}{|c|}{$\begin{array}{l}\text { Нарушение осанки, } \\
\text { \%о }\end{array}$} & \multicolumn{2}{|c|}{$\begin{array}{c}\text { Сколиоз, } \\
\% \text { \% }\end{array}$} & \multicolumn{2}{|c|}{$\begin{array}{l}\text { Нарушение остроты } \\
\text { зрения, \%o }\end{array}$} \\
\hline & Города & Районы & Города & Районы & Города & Районы \\
\hline $\begin{array}{l}\text { Перед поступлением в детское дошкольное } \\
\text { учреждение }\end{array}$ & 8,2 & 9,9 & 0,7 & 0,2 & 16,4 & 41,3 \\
\hline За год до поступления в школу & 5,6 & 134,5 & 3,9 & 3,2 & 43,1 & 76,6 \\
\hline Перед поступлением в школу & 87,6 & 203,9 & 11,7 & 10,2 & 82,4 & 82,9 \\
\hline В конце 1-го года обучения & 136,8 & 292,5 & 19,4 & 19,9 & 121,3 & 148,6 \\
\hline При переходе к предметному обучению & 166,0 & 367,4 & 33,1 & 47,0 & 165,7 & 277,0 \\
\hline В возрасте 15 лет включительно & 149,3 & 301,8 & 73,0 & 107,8 & 230,0 & 337,3 \\
\hline Перед окончанием школы & 106,7 & 215,7 & 64,2 & 129,8 & 188,7 & 348,5 \\
\hline
\end{tabular}

свидетельствует о снижении частоты данной патологии в этих возрастных группах. В районах среднегодовая частота выявления нарушений осанки у детей в 2 раза (и более) выше, чем городах, начиная с периода за год до поступления в школу и до окончания школы (т.е. с 6 до 17 лет включительно) (табл. 2).

«Группу риска» по сколиозу составляют подростки 15-17 лет, среди осмотренных в этом возрасте у 9,6\% выявлен сколиоз, что в 9 раз выше по сравнению с поступающими в школу. Высокий темп прироста нарушения осанки (в 10,4 раза) и сколиоза (в 8,6 раза) в динамике за 6-летний период установлен среди детей за год до поступления в школу (6 лет). Частота сколиоза увеличивается в среднем в 1,8 раза за первый год обучения в школе и в 8,8 раза - к концу периода обучения. В районах среднегодовая частота выявления нарушения осанки у детей в 1,4-2,0 раза больше, чем городах, начиная с периода обучения в 4-5-м классе (т.е. при переходе к предметному обучению) и до окончания школы.

Максимальные уровни распространенности нарушения зрения у детей в целом по Архангельской области $(294,4 \%$ \%) наблюдаются перед окончанием обучения в школе (10-11-е классы). В группах детей от поступления в детское дошкольное учреждении до поступления в 10-й класс в возрасте 15 лет доля патологии нарушения остроты зрения нарастает с каждым учебным годом, но в возрасте 16-17 лет наблюдается незначительное снижение показателя. В районах Архангельской области частота нарушения остроты зрения во всех возрастных группах детей выше по сравнению с аналогичными показателями у проживающих в городах (см. табл. 2).

При проведении корреляционного анализа в районах Архангельской области установлены статистически значимые связи между замерами уровней освещенности, не соответствующими гигиеническим нормативам, в детских дошкольных учреждениях и сколиозом у детей перед поступлением в школу $\left(r_{s}=0,472 ; p=0,048\right)$, а также между замерами мебели, не отвечающими санитарным требованиям, в компьютерных классах школ и нарушением остроты зрения у детей в $10-11$ лет $\left(r_{s}=0,529 ; p=0,024\right)$. В городах Архангельской области выявлена статистически значимая зависимость между удельным весом замеров мебели, не соответствующих санитарным требованиям, в детских дошкольных учреждениях, и нарушением осанки у детей за год до поступления и непосредственно перед поступлением в школу $\left(r_{s}=0,601\right.$; $p=0,008$ и $r_{s}=0,90 ; p=0,037$ соответственно).

Таким образом, по данным профилактических медицинских осмотров детей и подростков-школьников на территории Архангельской области основными патологиями являются нарушение осанки, сколиоз и нарушение остроты зрения. Наибольшая частота нарушений осанки выявлена у детей при переходе к предметному обучению, интенсивность сколиоза и нарушения остроты зрения наиболее выражены в возрастной группе 15 лет. Установлены статистически значимые данные среди: удельного веса замеров уровней освещенности, не соответствующих гигиеническим нормативам, и частоты сколиоза у детей перед поступлением в школу; замеров мебели, не отвечающих санитарным требованиям, в компьютерных классах школ и нарушений остроты зрения у детей в 10-11 лет; а также замеров мебели, не соответствующих санитарным требованиям, в детских дошкольных учреждениях и нарушений осанки у детей за год до поступления и непосредственно перед поступлением в школу. 


\section{Список литературы}

1. Айзман Р.И. Мониторинг здоровья учащихся, студентов и преподавателей: теоретические и прикладные аспекты // Здоровьесберегающее образование. - 2009. - № 2. - С. 14-19.

2. Базарный В.Ф. Школьный стресс и демографическая катастрофа России. - М., 2004. - 297 с.

3. Баранов А.А., Кучма Р.В., Сухарева Л.М. Здоровье, обучение и воспитание детей: история и современность. - М., 2006. - 247 с.

4. Безруких М.М. Здоровьесберегающая школа. - М.: МПСИ, 2004. - 240 с.

5. Гуров В.А. Влияние технологического компонента образовательной среды на процесс психофизиологического развития младших школьников. - Красноярск: Поликом, 2008. - 258 с.

6. Гуров В.А. Методологические основы мониторинга здоровьесберегающей деятельности в школе // Научно-педагогическое обозрение. - 2014. - № 1 (3). - С. 76.

7. Гуров В.А. Тревожность и здоровье младших школьников // Вестник Томского гос. пед. ун-та. 2009. - Вып. 4 (82). - С. 56-60.

8. Жукова Е.А., Циркин В.И. Две тенденции в возрастной динамике остроты зрения мальчиков и девочек на протяжении обучения в средней школе // Сенсорные системы. - 2008. - Т. 22, № 3. - С. 241-247.

9. Здоровье детей в образовательных учреждениях. Организация и контроль / под ред. М.Ф. Рзянкиной, В.Г. Молочного. - Н. Новгород: Феникс, 2005. -376 с.

10. Кучма В.Р., Степанова М.И. Стресс у школьников: причины, последствия, профилактика // Медицина труда и промышленная экология. - 2001. - № 8. - С. 32-37.

11. Кучма В.Р., Сухарева Л.М. Приоритетные критерии оценки состояния здоровья и профилактики заболеваний детей и подростков // Гигиена и санитария. - 2005. - № 6. - С. 42-45.

12. Микляева А.В., Румянцева П.В. Школьная тревожность: диагностика, коррекция, развитие. - СПб.: Речь, 2004. - 248 с.

13. Нефедовская Л.В. Миопия у детей как медико-социальная проблема // Рос. педиатр. журн. - 2008. № 2. - С. 50-53.

14. Сидоренко Е.И. Проблемы и перспективы детской офтальмологии: доклад по охране зрения детей // Вестник офтальмологии. - 2006. - № 1. - С. 41-42.

15. Сураева Л.М. Проектирование и реализация системы оздоровительных технологий в допрофессиональном образовании учащихся: дис... канд.пед.наук. - Тольятти, 2002. - 225 с.

16. Теоретико-прикладные аспекты здоровья как базовой адаптивной, личностной и социальной ценности. Сообщение 1. Социально-биологическая основа здоровья и адаптивных возможностей индивида / Э.М. Казин, Е.К. Айдаркин, А.И. Федоров, Н.Э. Касаткина, И.А. Свиридова // Валеология. - 2012. - № 2. C. 7-13.

17. Теппер Е.А., Таранушенко Т.Е., Гришкевич Н.Ю. Особенности формирования «школьной» патологии в течение десяти лет обучения // Саратовский научно-медицинский журнал. - 2013. - Т. 9, № 1. - С. 101-106.

18. Чечельницкая С.М. Нарушения осанки у детей. - Ростов-н/Д.: Феникс, 2009. - 286 с.

\section{References}

1. Ayzman R.I. Monitoring zdorov'ja uchashhihsja, studentov i prepodavatelej: teoreticheskie i prikladnye aspekty [Monitoring of health of schoolchildren, students and teachers: theoretical and applied aspects] Zdorov'esberegajushhee obrazovanie, 2009, no. 2, pp. 14-19.

2. Bazarnyi V.F. Shkol'nyj stress i demograficheskaja katastrofa Rossii [School stress and demographic catastrophe of Russia]. Moscow, 2004. 297 p.

3. Baranov A.A., Kuchma R.V., Suhareva L.M. Zdorov'e, obuchenie i vospitanie detej: istorija i sovremennost' [Health, education and upbringing of children: history and contemporaneity]. Moscow, 2006. 247 p.

4. Bezrukih M.M. Zdorov'esberegajushhaja shkola. Moscow: MPSI, 2004. 240 p.

5. Gurov V.A. Vlijanie tehnologicheskogo komponenta obrazovatel'noj sredy na process psihofiziologicheskogo razvitija mladshih shkol'nikov [Influence of technological component of the educational environment on the process of psycho-physiological development of schoolchildren]. Krasnoyarsk: Polikom, 2008. 258 p.

6. Gurov V.A. Metodologicheskie osnovy monitoringa zdorov'esberegajushhej dejatel'nosti v shkole [Methodological bases of health saving monitoring activities at school] Nauchno-pedagogicheskoe obozrenie, 2014, no. 1 (3), pp. 76.

7. Gurov V.A. Trevozhnost' i zdorov'e mladshih shkol'nikov [Anxiety and health of schoolchildren] Vestnik Tomskogo gosudarstvennogo pedagogicheskogo universiteta, 2009, issue 4 (82), pp. 56-60.

8. Zhukova E.A., Tsirkin V.I. Dve tendencii v vozrastnoj dinamike ostroty zrenija mal'chikov i devochek na protjazhenii obuchenija $\mathrm{v}$ srednej shkole [Two tendencies in the age dynamics of visual acuity of boys and girls when studying in secondary school] Sensornye sistemy, 2008, vol. 22, no. 3, pp. 241-247.

9. Zdorov'e detej v obrazovatel'nyh uchrezhdenijah. Organizacija i kontrol' [Health of children in educational institutions. Organization and control]. Edit by M.F. Rzyankina, V.G. Molochnyj. Nizhny Novgorod: Feniks, 2005. 376 p. 
10. Kazin Je.M., Aydarkin E.K., Fedorov A.I., Kasatkina N.Je., Sviridova I.A. Teoretiko-prikladnye aspekty zdorov'ja kak bazovoj adaptivnoj, lichnostnoj i social'noj cennosti. Soobshhenie 1. Social'no-biologicheskaja osnova zdorov'ja i adaptivnyh vozmozhnostej individa [Theoretical and applied aspects of health as a basic adaptive, personal and social values. Message 1. Socio-biological basis of health and adaptive possibilities of individual] Valeologija, 2012, no. 2, pp. 7-13.

11. Kuchma V.R., Stepanova M.I. Stress u shkol'nikov: prichiny, posledstvija, profilaktika [Stress in schoolchildren: causes, consequences, prevention] Medicina truda i promyshlennaja jekologija, 2001, no. 8, pp. 32-37.

12. Kuchma V.R., Suhareva L.M. Prioritetnye kriterii ocenki sostojanija zdorov'ja i profilaktiki zabolevanij detej i podrostkov [Priority criteria for assessing of health status and diseases prevention of children and adolescents] Gigiena i sanitarija, 2005, no. 6, pp. 42-45.

13. Miklyaeva A.V., Rumyanceva P.V. Shkol'naja trevozhnost': diagnostika, korrekcija, razvitie [School anxiety: diagnostics, correction, development]. St. Petersburg: Rech', 2004. 248 p.

14. Nefedovskaya L.V. Miopija u detej kak mediko-social'naja problema [Myopia in children as a medical and social problem] Rossijskij pediatricheskij zhurnal, 2008, no. 2, pp. 50-53.

15. Sidorenko E.I. Problemy i perspektivy detskoj oftal'mologii: doklad po ohrane zrenija detej [Problems and perspectives of children's ophthalmology: report on the protection of sense of vision in children] Vestnik oftal'mologii, 2006, no. 1, pp. 41-42.

16. Suraeva L.M. Proektirovanie i realizacija sistemy ozdorovitel'nyh tehnologij v doprofessional'nom obrazovanii uchashhihsja: dis. ... kand. ped. nauk [Design and implementation of system of healthful technologies in toprofessional education of schoolchildren: Dis. ... Cand. of Ped. sciences].Tolyatti, 2002. 225 p.

17. Tepper E.A., Taranushenko T.E., Grishkevich N.Ju. Osobennosti formirovanija «shkol'noj» patologii v techenie desjati let obuchenija [Features of formation of "school" pathology within ten years of education] Saratovskij nauchno-medicinskij zhurnal, 2013, vol. 9, no. 1, pp. 101-106.

18. Chechel'nickaja S.M. Narushenija osanki u detej [Postural disorder in children]. Rostov-on-Don: Feniks, 2009. $286 \mathrm{p}$.

\title{
EFFECT OF THE EDUCATIONAL ENVIRONMENT ON CHILDREN'S HEALTH AT PRESCHOOL AND SCHOOL AGE IN THE ARKHANGELSK REGION
}

\author{
R.V. Buzinov ${ }^{1}$, E.A. Averina ${ }^{2}$, T.N. Unguryanu ${ }^{1}$ \\ ${ }^{1}$ Directorate of the Federal Service for Consumer Rights Protection and Human Well-Being Surveillance in the \\ Arkhangelsk Region, Russian Federation, Arkhangelsk, 24 Gaidara St., 163000 \\ ${ }^{2}$ FBHI "Center of Hygiene and Epidemiology in the Arkhangelsk Region", Russian Federation, Arkhangelsk, \\ Building 1, house 164, Troitsky Pr., 163001
}

The descriptive epidemiological study on the prevalence of "school" pathology in the child population and the influence of the conditions of educational environment in kindergartens and schools in the Arkhangelsk Region was performed. It was found that the main health problems detected during preventive medical examinations of the children and adolescents of school age are the violation of posture, scoliosis and impaired visual acuity. The highest frequency of posture disorders found in children in the transition to subject teaching, the intensity of scoliosis and impaired visual acuity are the most pronounced in the age group of 15 years. The association between measuring light levels, not meeting hygienic standards and the frequency of scoliosis in children before entering school is revealed ( $r s=0,472 ; p=0,048)$; between measurements of furniture, not meeting sanitary requirements in school computer classes and the violation of visual acuity in children of 10-11 years ( $r s=0,529 ; p=0,024)$; and between measurements of furniture, not meeting sanitary requirements in kindergartens and the violation of posture in children one year before admission and just before entering school ( $r s=0,601 ; p=0,008$ and $r s=0,90 ; p=0,037$, respectively).

Key words: children of preschool and school age, medical examinations, incorrect posture, disturbance of visual acuity, educational environment, lighting, school furniture.

(C) Buzinov R.V., Averina E.A., Unguryanu T.N., 2015

Buzinov Roman Vyacheslavovich - Doctor of Medicine, Head (e-mail: arkh@29.rospotrebnadzor.ru; tel. +7 (8182) 20-5-69).

Averina Ekaterina Andreevna - Doctor (e-mail: averina-ea@mail.ru; tel. +7 (8182) 27-64-83).

Ungureanu Tatyana Nikolaevna - Doctor of Medicine, Chief Expert (e-mail: unguryanu_tn@mail.ru; tel. +7 (8182) 21-4-61). 


\title{
ГИГИЕНИЧЕСКАЯ ОЦЕНКА ОКРУЖАЮЩЕЙ СРЕДЫ И ЗДОРОВЬЯ ДЕТЕЙ ГОРОДА ПЕНЗЫ
}

\author{
Ю.В. Корочкина ${ }^{1}$, М.В. Перекусихин ${ }^{2}$ В.В. Васильев ${ }^{3,4}$, Г.В. Пантелеев ${ }^{1}$ \\ 1 ФБУЗ «Центр гигиены и эпидемиологии в Пензенской области», Россия, 440036, г. Пенза, \\ ул. Маршала Крылова, 3 \\ 2Управление Роспотребнадзора по Пензенской области, Россия, 440026, г. Пенза, ул. Лермонтова, 36 \\ ${ }^{3}$ ФБОУ ВПО «Пензенский государственный университет», Россия, 440026, г. Пенза, ул. Красная, 40 \\ ${ }^{4}$ ГБУЗ «Пензенская областная клиническая больница им. Н.Н. Бурденко», Россия, 440026, г. Пенза, \\ ул. Лермонтова, 28
}

Оиенка каниерогенного риска, обусловленного загрязнением атмосферного воздуха, химическим составом питьевой воды и содержанием контаминантов в пищевых продуктах, показала, что суммарный канцерогенный риск как для ингаляиионного, так и для перорального пути поступления приоритетных загрязнителей и контаминантов в организм детей и подростков г. Пензы соответствует предельно допустимому уровню. Наибольший риск неканиергенного воздействия, связанного с загрязнением атмосферного воздуха, формируется в отнотении органов дыхания, зрения и иммунной системы. Максимальные индексы опасности, связанные с потреблением питьевой воды, установлены для крови, гормональной системы, почек. Риск негативных воздействий, связанных с поступлением контаминантов с пищевыми продуктами, отмечен в отномении кроветворной и сердечно-сосудистой систем. Применение методологии оченки риска для изучения влияния химических веществ, загрязняющих окружающую среду, на здоровье позволило обосновать профилактические мероприятия, направленные на снижение риска для здоровья детей и подростков, а также расширение мониторинговых исследований объектов окружающей среды с иелью выделения зон повышенного риска для здоровья детского населения.

Ключевые слова: оценка риска, канцерогенный и неканцерогенный риски, атмосферный воздух, питьевая вода, пищевые продукты, дети.

Рост промышленного производства в стране не всегда сопровождается существенным улучшением качества среды обитания и, как следствие, уровень защиты населения и окружающей среды не достигает состояния, при котором отсутствуют недопустимые риски причинения вреда от воздействия опасных химических и биологических факторов $[1,4,7,9]$. Вклад загрязнения атмосферного воздуха, питьевых вод, почвы химическими компонентами в смертность населения составляет в среднем $11,4 \%$, в заболеваемость - 12,5\% [7].

В последнее десятилетие в гигиенических исследованиях при оценке влияния среды обитания на здоровье все большее внимание уделяется расчетам рисков и ущербов здоровью населения, необходимых для обоснования принятия управленческих решений [3, 6, 8, 12-15].
Методология оценки риска имеет особое значение при определении значимости для организма детей длительного воздействия химических веществ на уровнях ниже регламентируемых. Показано, что даже при концентрации химического вещества в объектах среды на уровне гигиенического регламента величина риска для здоровья детского населения может быть достаточно высокой $[2,4,11]$. Поэтому вероятность возникновения неблагоприятных эффектов при воздействии веществ, загрязняющих окружающую среду, определяемую как уровень риска для здоровья, целесообразно применять для обоснования разработки профилактических мероприятий в конкретном регионе и населенном пункте $[6,10]$.

По итогам 2014 г. Пензенская область отнесена к группе регионов с довольно благопри-

(C) Корочкина Ю.В., Перекусихин М.В., Васильев В.В., Пантелеев Г.В., 2015

Корочкина Юлия Валентиновна - заместитель главного врача по лабораторному обеспечению, метрологии, стандартизации и аккредитации (e-mail: korochkina@cge58.ru; тел. (8412) 54-85-94).

Перекусихин Михаил Владимирович - руководитель (e-mail: sanepid@sura.ru; тел. (8412) 55-26-06).

Васильев Валерий Валентинович - доктор медицинских наук, профессор кафедры гигиены, общественного здоровья и здравоохранения, врач-методист организационно-методического отдела (e-mail: vvv1755@yandex.ru; тел. 8-9093160197, тел. (8412) 59-17-46).

Пантелеев Геннадий Валентинович - главный врач (e-mail: panteleev@cge58.ru; тел. (8412) 54-85-94). 
ятными показателями санитарно-эпидемиологического благополучия [7]. Однако проблемы нарушений здоровья, ассоциированные с негативным воздействием факторов среды обитания, сохраняются, что требует осмысления и принятия мер по улучшению ситуации $[4,5]$.

Цель исследования - изучение влияния факторов среды обитания на здоровье детского населения города Пензы с применением методики оценки риска для обоснования мероприятий, направленных на снижение риска для здоровья детей и подростков.

Материалы и методы. В работе проанализированы данные регионального информационного фонда социально-гигиенического мониторинга за 2007-2014 гг. по г. Пензе. Статистической обработке подвергнуты результаты санитарно-химических лабораторных исследований питьевой воды (83 352 исследования), атмосферного воздуха (55 833 исследования), почвы (7513 исследований), продовольственного сырья и пищевых продуктов на различные контаминанты (4507 образцов). Для выбора необходимой информации по определению приоритетных факторов среды обитания, формирующие негативные тенденции в состоянии здоровья, использован подход, базирующийся на принципе отбора показателей реального и потенциального загрязнения, включающих ведущие загрязнители объектов среды обитания, оценку направленности действия, на основе которых отобраны показатели здоровья.

Оценка риска при хроническом воздействии химических веществ проведена в соответствии с Р 2.1.10.1920-04 «Руководство по оценке риска для здоровья населения при воздействии химических веществ, загрязняющих окружающую среду» и МУ 2.3.7.2519-09 «Определение экспозиции и оценка риска для здоровья населения при воздействии химических контаминантов пищевых продуктов на население». Для расчета экспозиции использованы медиана и 90-й процентиль содержания химических веществ в пищевых продуктах.

С целью определения влияния загрязняющих веществ атмосферного воздуха на здоровье населения рассчитывался риск развития канцерогенных и неканцерогенных эффектов. Неканцерогенный риск характеризовался величинами коэффициентов $(H Q)$ и индексов опасности $(H I)$. При превышении единицы по каждому из этих показателей риск рассматривали как недопустимый. Канцерогенный риск выражали через вероятность возникновения онкологического заболе- вания в течение жизни. К веществам, определяющим канцерогенный риск, были отнесены формальдегид и свинец.

Результаты и их обсуждение. К приоритетным загрязнителям атмосферного воздуха от промышленных предприятий и автотранспорта в городе Пензе по данным многолетних наблюдений относятся следующие химические вещества: взвешенные вещества, серы диоксид, азота диоксид, углерода оксид, формальдегид, свинец. Согласно результатам мониторинга, осуществленного в 2007-2014 гг. на 8 стационарных постах, расположенных во всех районах города, среднемноголетняя концентрация азота диок-

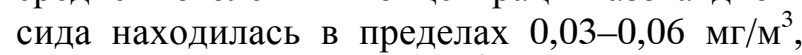

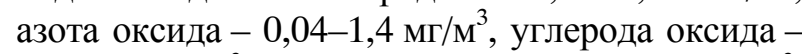

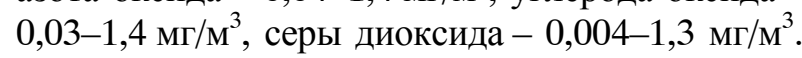
Концентрации формальдегида регистрирова-

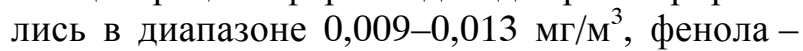
$0,002 \mathrm{мг} / \mathrm{M}^{3}$, взвешенных веществ - 0,04-0,16

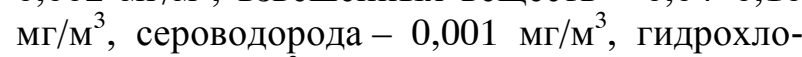
рида $-0,08$ мг $/ \mathrm{M}^{3}$.

Наибольшее число проб, превышающих 1 ПДК, было отмечено по формальдегиду (2,3\%), серы диоксиду и оксиду углерода (соответственно 0,92 и 0,67 \%). Количество проб, в которых концентрации веществ превышали 2 и 3 ПДК, было незначительным - менее $0,01 \%$. Вместе с тем уровень загрязнения атмосферного воздуха Пензы расценивается как высокий: индекс загрязнения атмосферы в 2007-2014 гг. составлял 10-11, что позволяло относить город к территориям «риска» по показателям загрязнения атмосферного воздуха. Под воздействием вредных веществ, превышающих гигиенические нормативы, постоянно проживает население общей численностью более 500000 человек, в том числе 84000 детей и подростков.

Установлено, что рассчитанный индивидуальный пожизненный канцерогенный риск для среднестатистического горожанина от воздействия формальдегида равен $0,3 \cdot 10^{-6}$, что следует оценивать как приемлемый риск, воспринимаемый всеми людьми как пренебрежительно малый, не отличающийся от обычных, повседневных рисков. Подобный риск не требует проведения дополнительных мероприятий по его снижению, но его уровень подлежит периодическому контролю.

Индивидуальный пожизненный канцерогенный риск от воздействия свинца в атмосферном воздухе определен на уровне $0,5 \cdot 10^{-5}$, что соответствует предельно допустимому риску, т.е. верхней границе приемлемого риска. 
Данные уровни подлежат постоянному контролю. В некоторых случаях при таких уровнях риска могут проводиться дополнительные мероприятия по их снижению. В целом суммарный канцерогенный риск для ингаляционного пути поступления соответствует предельно допустимому и подлежит постоянному контролю.

При общей численности населения г. Пензы порядка 520000 популяционный канцерогенный риск от воздействия формальдегида, загрязняющего атмосферный воздух, составляет порядка 0,02 дополнительного случая рака ежегодно, от ингаляционного воздействия свинца - 3,7 дополнительного случая злокачественных новообразований в год.

Оценка риска появления неканцерогенных заболеваний у детей и подростков города показала, что существует вероятность возникновения вредных эффектов при ежедневном поступлении загрязняющих веществ из атмосферного воздух. Приоритетные факторы рискасвинец и его соединения, формальдегид, пыли, азота диоксид (табл. 1).

Риск развития неканцерогенных эффектов отмечается по 9 органам и системам (мишеням), а именно: органы дыхания, ЦНС, система крови, репродуктивная и гормональная системы, почки, сердечно-сосудистая система, система органов зрения, иммунная система. В условиях комбинированного воздействия наибольшую токсико- логическую нагрузку испытывают органы дыхания $(H I=6,65)$, органы зрения и иммунная система $(H I=3,28)$ (табл. 2).

При ранжировании химических веществ по величине коэффициента опасности определены приоритетные загрязнители атмосферного воздуха: свинец, взвешенные вещества, серы диоксид. Расчет коэффициента опасности по отдельным загрязняющим веществам позволил определить вклад в суммарную величину индекса опасности: свинец - $37 \%$, взвешенные вещества - $25 \%$, серы диоксид - $18 \%$.

К веществам, определяющим канцерогенный риск при потреблении питьевой воды, прежде всего были отнесены кадмий и свинец. Индивидуальный канцерогенный риск от воздействия кадмия, равный $0,9 \cdot 10^{-5}$, относится ко второму диапазону и соответствует предельно допустимому уровню. Популяционный канцерогенный риск от воздействия кадмия, загрязняющего воду, равен 12,4. Индивидуальный канцерогенный риск от воздействия свинца в питьевой воде, равный $0,8 \cdot 10^{-5}$, относится также ко второму диапазону. Популяционный канцерогенный риск от воздействия свинца, загрязняющего воду, равен 11, а популяционный годовой канцерогенный риск - 0,16. Суммарный канцерогенный риск для перорального пути поступления равен $1,7 \cdot 10^{-5}$ и относится ко второму диапазону риска, что соответ-

Т аблиц а 1

Факторы и показатели неканцерогенного ингаляционного риска для детей г. Пензы

\begin{tabular}{|l|c|c|c|c|}
\hline \multicolumn{1}{|c|}{ Вещество } & $\begin{array}{c}\text { Доза, } \\
\text { мг/кг }\end{array}$ & $\begin{array}{c}R f C, \\
\text { мг/кг }\end{array}$ & $H Q$ & Поражаемый орган, система \\
\hline Свинец & 0,002 & 0,0005 & 4,00 & $\begin{array}{c}\text { Центральная нервная система, кровь, репродуктивная система, } \\
\text { гормональная система, почки }\end{array}$ \\
\hline Формальдегид & 0,01 & 0,003 & 3,28 & Органы дыхания, органы зрения, иммунная система \\
\hline Взвешенные вещества & 0,17 & 0,075 & 2,06 & Органы дыхания \\
\hline Азота диоксид & 0,043 & 0,04 & 1,17 & Органы дыхания \\
\hline Угерода оксид & 1,12 & 3 & 0,38 & Сердечно-сосудистая система \\
\hline Серы диоксид & 0,006 & 0,05 & 0,14 & Органы дыхания \\
\hline
\end{tabular}

Таблица 2

Риски негативного ингаляционного воздействия на критические органы и системы детей г. Пензы

\begin{tabular}{|l|c|c|}
\hline \multicolumn{1}{|c|}{ Поражаемые органы и системы } & Индекс опасности & Приоритетные факторы риска \\
\hline Органы дыхания & 6,65 & Формальдегид, взвешенные вещества, азота диоксид \\
\hline Кровь & 4,00 & Свинец \\
\hline Центральная нервная система & 4,00 & Свинец \\
\hline Сердечно-сосудистая система & 0,38 & Углерода оксид \\
\hline Иммунная система & 3,28 & Формальдегид \\
\hline Органы зрения & 3,28 & Формальдегид \\
\hline Репродуктивная система & 4,00 & Свинец \\
\hline Гормональная система & 4,00 & Свинец \\
\hline Почки & 4,00 & Свинец \\
\hline
\end{tabular}


ствует предельно допустимому уровню, т.е. верхней границе приемлемого риска.

Питьевая вода из Сурского водохранилища, используемая для водоснабжения населения г. Пензы, наиболее часто не отвечает гигиеническим нормативам по содержанию железа, мутности, цветности, перманганантной окисляемости, имеют место случаи превышения нормативов по связанному остаточному хлору, хлороформу. Анализ имеющихся данных о питьевой воде городского водопровода позволяет высказать определенные опасения о подверженности населения города воздействию хлорорганических соединений, определяемых в воде: хлороформа, трихлорметана и образования тригалометанов. Установлено, что питьевая вода имеет достаточно высокий уровень канцерогенного риска, в первую очередь за счет воздействия тетрахлорэтилена и хлороформа. Этот риск в Пензе в 1,6 раза выше, чем в микрорайоне Заря, водоснабжение которого осуществляется из подземных источников. В Пензе вклад питьевой воды в канцерогенный риск составляет $19 \%$.

Неканцерогенный риск формируют повышенные уровни в питьевой воде нитритов и ряда соединений тяжелых металлов (табл. 3). Коэффициент опасности более единицы установлен для нитритов, кадмия, свинца и железа и др. Несмотря на то что уровень остальных веществ не превышает порога коэффициента опасности, их следует рассматривать суммарно.

Таблица 3

Факторы и показатели неканцерогенного риска для здоровья детей г. Пензы, связанного с питьевой водой

\begin{tabular}{|l|c|c|c|c|}
\hline Вещество & $\begin{array}{c}\text { Доза, } \\
\text { мг/кг }\end{array}$ & $\begin{array}{c}R f D, \\
\text { мг/кг }\end{array}$ & $H Q$ & $\begin{array}{c}\text { Поражаемый орган, } \\
\text { система }\end{array}$ \\
\hline Нитриты & 0,24 & 0,1 & 2,4 & Кровь \\
\hline Кадмий & 0,0009 & 0,0005 & 1,8 & $\begin{array}{c}\text { Почки, гормональная } \\
\text { система }\end{array}$ \\
\hline Свинец & 0,006 & 0,0035 & 1,7 & $\begin{array}{c}\text { Центральная нервная } \\
\text { система, гормональная } \\
\text { системы }\end{array}$ \\
\hline Железо & 0,37 & 0,3 & 1,2 & $\begin{array}{c}\text { Слизистые, кровь, кожа, } \\
\text { иммунная система }\end{array}$ \\
\hline Молибден & 0,0025 & 0,0025 & 1,0 & Почки \\
\hline Нитраты & 1,49 & 1,6 & 0,9 & $\begin{array}{c}\text { Кровь, сердечно-сосу- } \\
\text { дистая система }\end{array}$ \\
\hline Марганец & 0,08 & 0,14 & 0,6 & $\begin{array}{c}\text { Центральная нервная } \\
\text { система, кровь }\end{array}$ \\
\hline Медь & 0,01 & 0,019 & 0,5 & $\begin{array}{c}\text { Желудочно-кишечный } \\
\text { тракт }\end{array}$ \\
\hline Алюминий & 0,26 & 1 & 0,26 & $\begin{array}{c}\text { Центральная нервная } \\
\text { система, кровь }\end{array}$ \\
\hline
\end{tabular}

В результате оценки неканцерогенного риска получены значения индекса опасности, приведенные в табл. 4. Недопустимый риск развития неканцерогенных эффектов отмечается по 10 органам и системам (мишеням): система крови, гормональная и иммунная системы, почки, центральная нервная система, нервная система, слизистые и кожа, сердечно-сосудистая система, желудочно-кишечный тракт. Наибольшие риски отмечены в отношении крови, гормональной системы, почек и центральной нервной системы.

В динамике за 2007-2014 гг. концентрации загрязняющих химических веществ в почве с учетом региональных фоновых уровней имеет тенденцию к снижению. В исследованиях почвы на содержание тяжелых металлов выявлено превышение фоновых показателей, рассчитанных в целом по Пензенской области: по свинцу в 1,1-5,3 раза, кадмию в 1,4-6,7 раза, цинку в 1,2-2,5 раза. Наиболее высокие значения содержания тяжелых металлов отмечались на территориях, расположенных рядом с городскими автомагистралями. По результатам исследований содержание солей тяжелых металлов в пробах почвы не превышает предельно допустимую концентрацию.

Безопасность питания детей и подростков оценена по основным группам пищевых продуктов, в которых изучено содержание таких контаминантов, как кадмий, мышьяк, свинец, нитраты, пестициды, микотоксины. В период с 2007 по 2014 г. согласно результатам социально-гигиенического мониторинга безопасности пищевых

Таблица 4

Риски негативного перорального воздействия на критические органы и системы детей г. Пензы

\begin{tabular}{|l|c|c|}
\hline $\begin{array}{c}\text { Поражаемый орган, сис- } \\
\text { тема }\end{array}$ & $\begin{array}{c}\text { Индекс } \\
\text { опасности }\end{array}$ & $\begin{array}{c}\text { Приоритетные } \\
\text { факторы риска }\end{array}$ \\
\hline Кровь & 3,90 & $\begin{array}{c}\text { Нитриты, соедине- } \\
\text { ния железа, нитраты }\end{array}$ \\
\hline Гормональная система & 3,50 & Кадмий, свинец \\
\hline Почки & 2,80 & Кадмий, молибден \\
\hline $\begin{array}{l}\text { Центральная нервная } \\
\text { система }\end{array}$ & 2,56 & Свинец, марганец \\
\hline Нервная система & 1,70 & Свинец, алюминий \\
\hline Слизистые & 1,24 & Соединения железа, \\
\hline Кожа & 1,20 & Соединения железа, \\
\hline Иммунная система & 1,20 & Соединения железа, \\
\hline $\begin{array}{l}\text { Сердечно-сосудистая } \\
\text { система }\end{array}$ & 0,90 & Нитраты \\
\hline $\begin{array}{l}\text { Желудочно-кишечный } \\
\text { тракт }\end{array}$ & 0,50 & Соединения меди \\
\hline
\end{tabular}


продуктов ежегодно выявлялись единичные случаи превышения гигиенических нормативов по содержанию кадмия (от 0,06 до 0,4\%), пестицидов $(0,5-0,6 \%)$ и нитратов $(0,2-2,1 \%)$, микотоксинов $(0,7-0,78 \%)$. Индивидуальный канцерогенный риск при пероральном поступлении с продуктами питания отдельно кадмия, свинца и мышьяка на уровне медианных значений является допустимым: для кадмия на уровне $2,2 \cdot 10^{-5}$, для свинца $-7,9 \cdot 10^{-5}$, мышьяка $-1,8 \cdot 10^{-4}$. Среднесуточная доза поступления в детский организм нитрата натрия составила 0,23 мг/кг, нитрита натрия - $0,11 \times$ $\times 10^{-4}$ мг/кг, гексахлорциклогексана - $0,13 \times$ $\times 10^{-5}$ мг/кг, дихлордифенилтрихлорэтана $0,16 \cdot 10^{-4}$ мг/кг, микотоксина $-0,01 \cdot 10^{-5}$ мг/кг.

Неканцерогенный риск для здоровья школьников, рассчитанный на уровне медианы содержания контаминантов в пищевых продуктах, не превысил 1,0. На уровне 90-го процентиля коэффициент неканцерогенной опасности $(H Q)$ от загрязнения пищевых продуктов кадмием составил в 2014 г. 1,5, по содержанию свинца - 2,4. Превышен допустимый уровень неканцерогенного риска также за счет контаминации продуктов питания мыщьяком $(H Q=3,1)$, нитратами $(2,4)$ и нитритами $(1,8)$.

Выявленное превышение допустимого уровня неканцерогенного риска позволяет говорить о возможных нарушениях состояния здоровья детей со стороны сердечно-сосудистой, центральной нервной, гормональной, кроветворной, иммунной систем, кожи и пищеварительного тракта.

Расчеты неканцерогенного риска показали, что преимущественный вклад в общую экспозицию свинцом вносят хлеб и хлебопродукты $(30 \%)$, овощи и бахчевые $(21 \%)$, молоко и молочные продукты (13\%). В экспозиции кадмием превалирует также вклад хлеба и хлебопродуктов - $37 \%$, овощей и бахчевых - $19 \%$ и картофеля - $18 \%$. Основной вклад в экспозицию мышьяком вносят рыба и рыбопродукты $43 \%$, хлеб и хлебопродукты - $18 \%$, овощи и бахчевые - $14 \%$. На картофель, овощи и бахчевые примерно поровну (51 и $49 \%$ соответственно) приходится вклад в экспозицию нитратами. Проведенные расчеты рисков неблагоприят- ного воздействия конаминантов, поступающих с продуктами питания, свидетельствуют о необходимости осуществления систематического мониторинга безопасности пищевых продуктов на региональном уровне.

На основании проведенных расчетов были сделаны выводы, что:

- в настоящее время суммарный канцерогенный риск как для ингаляционного, так и для перорального пути поступления приоритетных токсикантов и контаминантов с пищевыми продуктами в организм детей и подростков г. Пензы соответствует предельно допустимому риску, не требует специальных мер по его снижению, но подлежит постоянному контролю;

- наибольшие уровни неканцерогенного риска, связанного с загрязнением атмосферного воздуха, формируются в отношении органов дыхания, органов зрения и иммунной системы. Недопустимый ингаляционный риск здоровью детей и подростков г. Пензы в основном определяется присутствием в среде обитания соединений свинца, пылей, а также формальдегида и диоксида азота;

- с химическим составом питьевой воды ассоциированы недопустимые риски возникновения болезней крови, гормональной системы, почек, а с поступлением контаминантов с пищевыми продуктами - риски болезней кроветворной и сердечно-сосудистой системы;

- неканцерогенный риск содержания контаминантов в пищевых продуктах для здоровья детей, рассчитанный на уровне медианы, не превысил допустимых уровней.

Применение методологии оценки риска для изучения влияния химических веществ, загрязняющих окружающую среду, на здоровье детского населения позволило обосновать профилактические мероприятия, направленные на снижение риска для данного контингента. Одним из таких мероприятий является предложение по расширению мониторинговых исследований загрязнения объектов окружающей среды с целью выделения зон повышенного риска для здоровья детского населения; формирование эколого-гигиенической культуры населения.

\section{Список литературы}

1. Горшков А.И., Черкасова Л.В., Осипова Е.М. Комплексная гигиеническая оценка окружающей среды и здоровья детей в Северном административном округе Москвы // Гигиена и санитария. - 2012. - № 2. С. $77-79$.

2. Зайцева Н.В., Шур П.З., Кирьянов Д.А. Анализ управляемых факторов риска неинфекционной патологии в Пермском крае // Уральский медицинский журнал. - 2013. - № 2. - С. 14-26. 
3. Макроэкономический анализ потерь здоровья, вероятностно обусловленных эмиссиями загрязняющих веществ в атмосферный воздух / С.А. Рыжаков, Н.В. Зайцева, И.В. Май, В.Б. Алексеев, М.Я. Подлужная, Д.А. Кирьянов // Пермский медицинский журнал. - 2009. - Т. 26, № 3. - С. 139-143.

4. Мизина Н.Г. Гигиеническая оценка риска для здоровья детского населения при воздействии тяжелых металлов, загрязняющих окружающую среду: автореф. дис. ... канд. мед. наук. - Кемерово, 2012. - 24 с.

5. Миненко Е.Ю., Курамшин Д.Ю. Воздействие автомобильного транспорта на окружающую среду и здоровье населения Пензы // Интернет-Вестник ВолгГАСУ. - 2014. - № 3 (34) . - С. 22.

6. Научно-методические и экономические аспекты решения региональных проблем в области медицины окружающей среды / Ю.А. Рахманин, Н.В. Зайцева, П.З. Шур, С.М. Новиков, И.В. Май, Д.А. Кирьянов, О.А. Кобякова // Гигиена и санитария. - 2005. - № 6. - С. 6.

7. О санитарно-эпидемиологическом благополучии населения в Российской Федерации в 2014 г.: Государственный доклад. - М.: Федеральная служба по надзору в сфере защиты прав потребителей и благополучия человека, 2015. - 206 с.

8. Онищенко Г.Г. Концепция риска и ее место в системе социально-гигиенического мониторинга (проблемы и пути решения) // Вестник Российской академии медицинских наук. - 2005. - № 11. - С. $27-33$.

9. Попова А.Ю. Стратегические приоритеты Российской Федерации в области экологии с позиции сохранения здоровья нации // ЗН и СО. - 2014. - № 2. - С. 4.

10. Рахманин Ю.А., Михайлова Р.Н. Окружающая среда и здоровье: приоритеты // Гигиена и санитария. - 2014. - № 5. - С. 5-10.

11. Установление и доказательства вреда здоровью гражданина, наносимого негативным воздействием факторов среды обитания / И.В. Май, Н.В. Зайцева, С.В. Клейн, Э.В. Седусова // Здоровье населения и среда обитания - 2013. - № 11. - С. 4-6.

12. Environmental Health Risk Assessment. Guidelines for assessing human health risks from environmental hazards / Commonwealth of Australia, 2004. Department of Health and Ageing and Health Council. Commonwealth of Australia, 2004. - 258 p.

13. Kolluru R.V. Health Risk Assessment Text: Principles and Practices // Risk Assessment and Management handbook. For Environmental, Health, and Safety Professionals. - New York, 1996. - P. 123.

14. McClellan R.O. Human health risk assessment: a historical overview and alternative paths forward // Inhalation Toxicology. - 1999. - № 11 (6-7). - P. 477-518.

15. Principles For The Assessment Of Risks To Human Health From Exposure To Chemicals: Environmental Health Criteria 210 / WHO. - 1999.

\section{References}

1. Gorshkov A.I., Cherkasova L.V., Osipova E.M. Kompleksnaja gigienicheskaja ocenka okruzhajushhej sredy i zdorov'ja detej v Severnom administrativnom okruge Moskvy [Complex hygienic evaluation of the environment and health of children in the northern administrative district of Moscow]. Gigiena i sanitarija, 2012, no. 2, pp. 77-79.

2. Zaitseva N.V., Shur P.Z., Kiryanov D.A. Analiz upravljaemyh faktorov riska neinfekcionnoj patologii v Permskom krae [Analysis of controlled risk factors of non-communicable pathology in Perm region]. Ural'skij medicinskij zhurnal, 2013, no. 2, pp. 14-26.

3. Ryzhakov S.A., Zaitseva N.V., May I.V., Alekseev V.B., Podluzhnaya M.Ja., Kiryanov D.A. Makrojekonomicheskij analiz poter' zdorov'ja, verojatnostno obuslovlennyh jemissijami zagrjaznjajushhih veshhestv v atmosfernyj vozduh [Macroeconomic analysis of losses of health, probabilistically caused by emissions of pollutants into air]. Permskij medicinskij zhurnal, 2009, vol. 26, no. 3. pp. 139-143.

4. Mizina N.G. Gigienicheskaja ocenka riska dlja zdorov'ja detskogo naselenija pri vozdejstvii tjazhelyh metallov, zagrjaznjajushhih okruzhajushhuju sredu: avtoref. dis. ... kand. med. nauk [Hygienic assessment of risk to children's health under the influence of heavy metals, polluting the environment: Auth. Dis. ... Candidate of Medical Science]. Kemerovo, 2012. 24 p.

5. Minenko E.Ju., Kuramshin D.Ju. Vozdejstvie avtomobil'nogo transporta na okruzhajushhuju sredu i zdorov'e naselenija Penzy [Influence of road transport on the environment and human health in Penza]. InternetVestnik VolgGASU, 2014, no. 3 (34), pp. 22.

6. Rahmanin Ju.A., Zaitseva N.V., Shur P.Z., Novikov S.M., May I.V., Kiryanov D.A., Kobyakova O.A. Nauchno-metodicheskie i jekonomicheskie aspekty reshenija regional'nyh problem $\mathrm{v}$ oblasti mediciny okruzhajushhej sredy [Scientific-methodical and economical aspects of solving of regional problems in the field of environmental medicine]. Gigiena i sanitarija, 2005, no. 6, pp. 6.

7. O sanitarno-jepidemiologicheskom blagopoluchii naselenija v Rossijskoj Federacii v 2014 g.: Gosudarstvennyj doklad [On sanitary and epidemiological welfare of the population in the Russian Federation in 2014.: State report]. Moscow: Federal'naja sluzhba po nadzoru v sfere zashhity prav potrebitelej i blagopoluchija cheloveka, 2015. $206 \mathrm{p}$. 
8. Onishhenko G.G. Koncepcija riska i ee mesto v sisteme social'no-gigienicheskogo monitoringa (problemy i puti reshenija) [Concept of risk and its place in the system of social and hygienic monitoring (problems and solutions) ]. Vestnik Rossijskoj akademii medicinskih nauk, 2005, no. 11, pp. 27-33.

9. Popova A.Ju. Strategicheskie prioritety Rossijskoj Federacii v oblasti jekologii s pozicii sohranenija zdorov'ja nacii [Strategic priorities of the Russian Federation in the field of ecology from the position of preservation of health of nation]. ZN i SO, 2014, no. 2, pp. 4.

10. Rahmanin Ju.A., Mihaylova R.N. Okruzhajushhaja sreda i zdorov'e: prioritety [Environment and health: priorities]. Gigiena i sanitarija, 2014, no. 5, pp. 5-10.

11. May I.V., Zaitseva N.V., Kleyn S.V., Sedusova Je.V. Ustanovlenie i dokazatel'stva vreda zdorov'ju grazhdanina, nanosimogo negativnym vozdejstviem faktorov sredy obitanija [Establishment and evidence of harm to health of a citizen caused by negative impact of environmental factors]. Zdorov'e naselenija i sreda obitanija, 2013, no. 11, pp. 4-6.

12.Environmental Health Risk Assessment. Guidelines for assessing human health risks from environmental hazards. Commonwealth of Australia, 2004. Department of Health and Ageing and Health Council. Commonwealth of Australia, 2004. 258 p.

13.Kolluru R.V. Health Risk Assessment Text: Principles and Practices []. Risk Assessment and Management handbook. For Environmental, Health, and Safety Professionals, New York, 1996. pp. 123.

14. McClellan R.O. Human health risk assessment: a historical overview and alternative paths forward []. Inhalation Toxicology, 1999, no. 11 (6-7), pp. 477-518.

15.Principles For The Assessment Of Risks To Human Health From Exposure To Chemicals: Environmental Health Criteria 210. WHO, 1999.

\title{
HYGIENIC ENVIRONMENTAL ASSESSMENT AND HEALTH OF CHILDREN IN PENZA
}

\author{
Yu.V. Korochkina1, M.V. Perekusikhin², V.V. Vasilyev ${ }^{3,4}$, G.V. Panteleev ${ }^{1}$ \\ ${ }^{1}$ FBHI “Center of Hygiene and Epidemiology in the Penza Region”, Russian Federation, Penza, Building 3, \\ Marshala Krylova St., 440036 \\ ${ }^{2}$ Directorate of Rospotrebnadzor in the Penza Region, Russian Federation, Penza, 36 Lermontova St., 440036 \\ ${ }^{3}$ FBEI HPE “Penza State University”, Russian Federation, Penza, 40 Krasnaya St., 440036 \\ ${ }^{4}$ SBSI "Penza Regional Clinical Hospital named after N.N. Burdenko", Russian Federation, 28 Lermontova St., 440036
}

Assessment of the carcinogenic risk from air pollution, the chemical composition of the drinking water and the content of contaminants in food showed that the total cancer risk for both inhalation and oral routes of administering priority pollutants and contaminants into the body of Penza children and adolescents complies with the maximum permissible level. The greatest risk of non-carcinogenic impact associated with air pollution is generated in respect of the respiratory system, eyes and immune system. The maximum hazard indices associated with the consumption of drinking water, are set for blood, hormone system and kidneys. The risk of negative impacts associated with the receipt of food contaminants is observed in respect of the hematopoietic and cardiovascular systems. Application of risk assessment methodology to study the effects of chemicals polluting the environment on health has allowed to justify preventive measures aimed at reducing the risk to the health of children and adolescents, as well as increased monitoring researches of environmental objects to isolate areas of high risk to children's health.

Key words: risk assessment, carcinogenic and non-carcinogenic risks, air, drinking water, food, children.

(C) Korochkina Yu.V., Perekusikhin M.V., Vasilyev V.V., Panteleev G.V., 2015

Korochkina Yulia Valentinovna - Deputy Chief Medical Officer for laboratory support, metrology, standardization and accreditation (e-mail: korochkina@cge58.ru; tel. (8412) 54-85-94).

Perekusikhin Mikhail Vladimirovich - Head (e-mail: sanepid@sura.ru; tel. (8412) 55-26-06).

Vasilyev Valery Valentinovich - Doctor of Medicine, Professor, Department of Hygiene and Public Health and Healthcare, Doctor-methodologist of Organizational and Methodical Department (e-mail: vvv1755@yandex.ru; tel. (8412) 59-17-46).

Panteleev Gennady Valentinovich - Chief Medical Officer (e-mail: panteleev@cge58.ru; tel. (8412) 54-85-94). 
УДК [614.71: 628.51]: 543.05/26

ГИГИЕНИЧЕСКАЯ ОЦЕНКА ВЛИЯНИЯ НА ЗДОРОВЬЕ НАСЕЛЕНИЯ ЗАГРЯЗНЕНИЯ АТМОСФЕРНОГО ВОЗДУХА С УЧЕТОМ КОМБИНИРОВАННОГО ДЕЙСТВИЯ ХИМИЧЕСКИХ ВЕЩЕСТВ В ЗОНЕ РАСПОЛОЖЕНИЯ ПРЕДПРИЯТИЯ ХИМИЧЕСКОЙ ПРОМЫШЛЕННОСТИ

\author{
Л.М. Шевчук ${ }^{1}$, Н.А. Толкачёва ${ }^{2}$, А.Е. Пшегрода ${ }^{1}$, И.П. Семёнов ${ }^{2}$ \\ ${ }^{1}$ РУП «Научно-практический центр гигиены», Республика Беларусь, 220012, г. Минск, ул. Академическая, 8 \\ ${ }^{2}$ УО «Белорусский государственный медицинский университет», Республика Беларусь, 220116, г. Минск, \\ пр-т Дзержинского, 83
}

Представлены результаты исследования степени загрязнения атмосферного воздуха в районе расположения предприятия химической промышленности, приведены результаты оценки возможсного влияния химического загрязнения на состояние здоровья населения по значениям показателей: комплексный показатель «Р», риск здоровью населения (рефлекторный, хронический, а также комбинированный риск при рефлекторном и хроническом действии), индекс опасности и коэффиииент комбинированного действия. Проведена сравнительная характеристика полученных данных по степени загрязнения атмосферного воздуха при оиенке с учетом и без такового комбинированного действия химических веществ. Определена возможность использования полученных результатов для прогнозирования изменений состояния здоровья населения и планирования эпидемиологических исследований.

Ключевые слова: химическое загрязнение атмосферы, комбинированное действие химических веществ, комбинированный риск действия химических веществ, коэффициент комбинированного действия.

Активный рост населенных пунктов, строительство и реконструкция промышленных предприятий, а также расширение жилой застройки за счет использования прилежащей к предприятиям и другим объектам территории определяют необходимость оценки принимаемых градостроительных решений с точки зрения степени неблагоприятного влияния на состояние здоровья проживающего рядом населения. Значимое влияние на состояние здоровья населения среди всех средовых факторов может оказывать загрязнение атмосферного воздуха $[3,11]$. По данным Всемирной организации здравоохранения загрязнение воздуха является наиболее важным отдельно взятым фактором экологического риска для здоровья в Европейском регионе $[12,14]$. Возрастание степени загрязнения атмосферного воздуха (при прочих равных условиях) проявляется увеличением заболеваемости населения острыми респиратор- ными инфекциями на 6-7 \% за счёт неспецифического влияния $[5,10]$.

Для принятия решений в области дальнейшего развития территории с точки зрения оценки возможных неблагоприятных эффектов за счет загрязнения атмосферного воздуха необходимо также учитывать многокомпонентный характер загрязнения атмосферного воздуха $[5,8,10,13]$.

В Республике Беларусь для принятия решений о возможности размещения различных объектов в районе расположения жилой территории большое значение имеют результаты оценки риска здоровью населения от воздействия загрязняющих веществ, выбрасываемых в атмосферный воздух объектом. Методология проведения данной процедуры осуществляется в соответствии с обширной базой нормативных и технических документов в данной области, а также по установленной методике. Проводимая в Республике Беларусь процедура оценки

( Шевчук Л.М., Толкачёва Н.А., Пшегрода А.Е., Семёнов И.П., 2015

Шевчук Лариса Михайловна - кандидат медицинских наук, доцент, заместитель директора по научной работе (e-mail: sheuchuklm@mail.ru; тел. +375 17 292-50-15).

Толкачёва Надежда Андреевна - ассистент кафедры гигиены труда (e-mail: gt@bsmu.by; тел. +375 17 365-84-43).

Пшегрода Александр Евгеньевич - старший научный сотрудник лаборатории факторов среды обитания и технологий анализа рисков здоровью (e-mail: risk.factors@rspch.by; тел. +375 17 292-47-00).

Семёнов Игорь Павлович - кандидат медицинских наук, доцент, заведующий кафедрой гигиены труда (e-mail: gt@bsmu.by; тел. +375 17 365-84-43). 
риска здоровью населения при принятии градостроительных решений является примером совместной работы между организациями охраны окружающей среды и охраны здоровья населения, что отражает стратегию развития и направления политики Всемирной организации здравоохранения в данном вопросе [14].

Методология оценки риска позволяет провести анализ принимаемых градостроительных решений для существующих (реконструируемых) и планируемых к возведению объектов с учетом многокомпонентности загрязнения атмосферного воздуха, а также разрабатывать необходимые профилактические мероприятия по защите здоровья населения от неблагоприятного влияния загрязняющих химических веществ, выбрасываемых в атмосферу объектом.

Цель работы - оценить влияние на здоровье населения загрязнения атмосферного воздуха с учетом комбинированного действия химических веществ в зоне расположения предприятия химической промышленности.

Материалы и методы. Анализ основных этапов технологического процесса производства; графические материалы по размещению источников выбросов основных производств предприятия по отношению к жилой застройке и территориям, нуждающимся в защите; моделирование распространения загрязняющих химических веществ, выбрасываемых предприятием, в атмосферном воздухе и анализ риска здоровью населения от воздействия данных веществ; результаты производственного контроля загрязнения атмосферного воздуха в районе расположения предприятия; фоновые концентрации загрязняющих химических веществ в районе расположения предприятия.

Результаты и их обсуждение. Для выделения группы приоритетных загрязняющих химических веществ, выбрасываемых промышленными объектами, а также для определения отраслей народного хозяйства, вносящих наибольший вклад в загрязнение атмосферного воздуха, были изучены материалы обследований и анализа риска 466 предприятий различных отраслей промышленности, расположенных в 219 населенных пунктах Республики Беларусь. По результатам исследования установлено, что к приоритетным веществам, загрязняющим атмосферный воздух, относятся оксиды азота, аммиак, диоксид серы, монооксид углерода, твердые частицы различных фракций, тяжелые металлы (ртуть, свинец, кадмий), а также летучие органические соединения. Определены наиболее активно развивающиеся отрасли промышленности, вносящие значительный вклад в загрязнение атмосферного воздуха в исследованных населенных пунктах. По результатам анализа было выбрано предприятие по производству карбамидоформальдегидных смол, клеев, красок и прочих органических веществ, расположенное в г. Борисове Минской области.

Предприятие располагается в промышленной зоне г. Борисова, образованной самим предприятием, комбинатом хлебопродуктов, мясоперерабатывающим комбинатом и рядом других промышленных предприятий на участке площадью 13,1446 га. В непосредственной близости от предприятия располагается жилая застройка города. В соответствии с [9] размер базовой санитарно-защитной зоны (далееС33) для объекта составляет 500 м. В ее пределах располагаются:

- с севера непосредственно к территории примыкает предприятие по производству пищевых продуктов (хлебокомбинат);

- с востока располагается пустырь, затем полоса отвода железной дороги, затем снова пустырь и на расстоянии 130-150 м от внешней границы предприятия (330-350 м от цеха нефтеполимерных смол) жилая усадебная застройка по ул.Сенная;

- с юга - территории промышленных предприятий;

- с запада - промзона;

- с северо-запада в пределах 200 м находится жилая застройка по ул.Строителей;

- с юго-запада расположен индивидуальный жилой сектор по ул.Демина, представленный двумя жилыми домами.

На территории предприятия расположено 232 (организованных и неорганизованных) источника выбросов загрязняющих химических веществ в атмосферу, суммарный валовый выброс от которых составляет 46,988 т/год. Данными источниками выбрасываются более 40 наименований вредных веществ. Среди значений валовых выбросов на долю веществ 1-го класса опасности приходится 0,03 \% суммарного валового выброса, 2-го класса опасности 27,39\%, 3-го - 9,56\%, 4-го - 62,08\%.

Для оценки степени загрязнения атмосферного воздуха в районе расположения предприятия были отобраны следующие территории: граница площадки предприятия (граница C33 на настоящий момент), близлежащая жилая зона - 130-150 м от границы площадки предприятия и жилая зона, находящаяся под 
влиянием объекта на расстоянии 210 м от границы площадки предприятия.

По результатам расчета рассеивания химических веществ на границе производственной площадки предприятия и близлежащей жилой зоны (130-150 м) и на расстоянии 210 м от границы площадки максимальные концентрации выбрасываемых веществ не превышают значений гигиенических нормативов, за исключением твердых частиц и формальдегида $(0,89-1,0$ и $1,08-1,1$ в долях ПДК соответственно). Среднегодовые концентрации для всех 32 веществ не превышают значений гигиенических нормативов. По результатам производственного контроля превышений значений гигиенических нормативов выявлено не было.

Проведена оценка степени загрязнения атмосферного воздуха с использованием комплексного показателя «Р» и комплексного индекса загрязнения атмосферы по 5 ведущим веществам (далее - КИЗА 5 ) (табл. 1).

Для оценки возможных эффектов влияния на здоровье человека выбрасываемых предприятием химических веществ были рассчитаны значения риска здоровью от воздействия выбрасываемых веществ (табл. 2).

Для проведения анализа возможных неблагоприятных эффектов при комбинированном действии химических веществ были вы- браны следующие показатели: комбинированный риск действия химических веществ, индекс опасности, коэффициент комбинированного действия $[6,10]$.

Рассчитано значение комбинированного риска развития рефлекторных эффектов для всей смеси химических веществ, выбрасываемых предприятием, основанное на методе умножения вероятностей [4]:

$$
\text { Risk }_{\mathrm{cym}}=1-\left(1-\text { Risk }_{1}\right)\left(1-\text { Risk }_{2}\right) \ldots \ldots\left(1-\text { Risk }_{\mathrm{n}}\right) \text {, }
$$

где Risk $k_{\text {сум }}$ - комбинированный риск действия

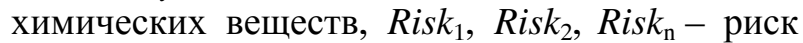
действия каждого отдельного вещества.

При расчете исходили из предположения о том, что хроническое воздействие химических веществ общетоксического характера на уровне малых концентраций характеризуется однотипными неспецифическими эффектами, что ведет к необходимости обязательного использования в этом случае уравнения расчета суммарного риска для всех веществ, входящих в состав выбросов и являющихся потенциальными токсикантами хронического действия [4]. Для острого воздействия была принята аналогичная гипотеза.

Значения комбинированного риска представлены в табл. 3.

Таблица 1

Степень загрязнения атмосферного воздуха в районе расположения объекта

\begin{tabular}{|l|c|c|c|}
\hline \multirow{2}{*}{ Показатель } & \multicolumn{3}{|c|}{ Территория } \\
\cline { 2 - 4 } & $\begin{array}{c}\text { Граница площадки } \\
\text { предприятия }\end{array}$ & $\begin{array}{c}\text { Жилая зона (130-150 м от } \\
\text { границы площадки } \\
\text { предприятия) }\end{array}$ & $\begin{array}{c}\text { 210 м от границы } \\
\text { площадки предприятия }\end{array}$ \\
\hline Комплексный показатель «Р» & 2,89 & 2,51 & 2,4 \\
\hline $\begin{array}{l}\text { Степень загрязнения атмосферы } \\
\text { по значению показателя «Р» }\end{array}$ & $\begin{array}{c}\text { Допустимая степень } \\
\text { загрязнения атмосферы }\end{array}$ & $\begin{array}{c}\text { Допустимая степень } \\
\text { загрязнения атмосферы }\end{array}$ & $\begin{array}{c}\text { Допустимая степень } \\
\text { загрязнения атмосферы }\end{array}$ \\
\hline КИЗА & 3,44 & 2,91 & 2,88 \\
\hline $\begin{array}{l}\text { Уровень загрязнения воздуха } \\
\text { по значению КИЗА }\end{array}$ & Низкий & Низкий & Низкий \\
\hline
\end{tabular}

Таблица 2

Риск здоровью от воздействия изолированных концентраций загрязняющих веществ

\begin{tabular}{|c|c|c|c|}
\hline \multirow[b]{2}{*}{ Показатель } & \multicolumn{3}{|c|}{ Территория } \\
\hline & $\begin{array}{c}\text { Граница площадки } \\
\text { предприятия }\end{array}$ & $\begin{array}{l}\text { Жилая зона (130-150 м от гра- } \\
\text { ницы площадки предприятия) }\end{array}$ & $\begin{array}{c}210 \text { м от границы } \\
\text { площадки предприятия }\end{array}$ \\
\hline $\begin{array}{l}\text { Максимальное значение риска } \\
\text { рефлекторного действия, \% }\end{array}$ & $\begin{array}{c}\text { 6,19 (для углеводородов пре- } \\
\text { дельных алифатического } \\
\left.\text { ряда } \mathrm{C}_{11}-\mathrm{C}_{19}\right)\end{array}$ & $\begin{array}{c}\text { 1,04 (для монооксида } \\
\text { углерода) }\end{array}$ & $\begin{array}{c}\text { 1,04 (для монооксида } \\
\text { углерода) }\end{array}$ \\
\hline Характеристика риска & Удовлетворительный & Приемлемый & Приемлемый \\
\hline $\begin{array}{l}\text { Максимальное значение риска } \\
\text { хронического действия, \% }\end{array}$ & $\begin{array}{c}\text { 5,07 (для углеводородов пре- } \\
\text { дельных алифатического } \\
\left.\text { ряда } \mathrm{C}_{11}-\mathrm{C}_{19}\right)\end{array}$ & $\begin{array}{c}\text { 1,3 (для углеводородов пре- } \\
\text { дельных алифатического ряда } \\
\left.\mathrm{C}_{11}-\mathrm{C}_{19}\right)\end{array}$ & $\begin{array}{c}1,11 \text { (для углеводородов } \\
\text { предельных алифатиче- } \\
\text { ского ряда } \mathrm{C}_{11}-\mathrm{C}_{19} \text { ) }\end{array}$ \\
\hline Характеристика риска & Вызывающий опасения & Приемлемый & Приемлемый \\
\hline
\end{tabular}


Таблица 3

Комбинированный риск рефлекторного и хронического действия

\begin{tabular}{|l|c|c|c|}
\hline \multirow{2}{*}{\multicolumn{1}{|c|}{ Показатель }} & \multicolumn{3}{|c|}{ Территория } \\
\cline { 2 - 4 } & $\begin{array}{c}\text { Граница площадки } \\
\text { предприятия }\end{array}$ & $\begin{array}{c}\text { Жилая зона (130-150 м } \\
\text { от границы площадки } \\
\text { предприятия) }\end{array}$ & $\begin{array}{c}210 \text { м от границы } \\
\text { площадки } \\
\text { предприятия }\end{array}$ \\
\hline $\begin{array}{l}\text { Значение комбинированного риска рефлек- } \\
\text { торного действия всей смеси, \% }\end{array}$ & 15,65 & 2,43 & 1,69 \\
\hline Характеристика риска & Удовлетворительный & Удовлетворительный & Приемлемый \\
\hline $\begin{array}{l}\text { Значение комбинированного риска хрониче- } \\
\text { ского действия всей смеси, \% }\end{array}$ & 28,49 & 14,72 & 16,18 \\
\hline Характеристика риска & Опасный & Вызывающий опасения & Опасный \\
\hline
\end{tabular}

Т аблица 4

ККД для групп суммации веществ, выбрасываемых предприятием

\begin{tabular}{|l|c|c|c|c|}
\hline \multicolumn{1}{|c|}{ Группа суммации } & $\begin{array}{c}\text { Граница } \\
\text { площадки } \\
\text { предприятия }\end{array}$ & $\begin{array}{c}\text { Жилая зона (130-150 м } \\
\text { от границы площадки } \\
\text { предприятия) }\end{array}$ & $\begin{array}{c}210 \text { м от границы } \\
\text { площадки } \\
\text { предприятия }\end{array}$ & $\begin{array}{c}\text { Нормативное } \\
\text { значение }\end{array}$ \\
\hline Аммиак, сероводород, формальдегид & 1,6 & 1,66 & -* $^{*}$ & 1 \\
\hline Аммиак, формальдегид & 1 & 1,3 & 1,1 & 1 \\
\hline $\begin{array}{l}\text { Азота диоксид, серы диоксид, углерода } \\
\text { оксид, фенол }\end{array}$ & 1,05 & 1,24 & 1,01 & 1 \\
\hline Сероводород, формальдегид & 1,25 & 1,4 & -* $^{*}$ \\
\hline
\end{tabular}

П р и м е ч а н и е : * - не проводился расчет рассеивания веществ, входящих в группу суммации (значение критерия целесообразности $E<0,001)$.

Значения комбинированных рисков развития рефлекторных и хронических эффектов от всей смеси более высокие, чем таковые максимальных рисков развития рефлекторных и хронических эффектов от одного вещества из смеси. Необходимо также иметь в виду, что эффекты немедленного действия чаще всего проявляются в виде рефлекторных реакций у наиболее чувствительных лиц, т.е. люди, наиболее подверженные воздействию одних примесей, оказываются более чувствительными и к другим. В связи с этим потенциальный риск немедленного действия при комбинированном воздействии можно приравнивать к максимальному риску отдельной примеси среди всех воздействующих ингредиентов, хотя необходим учет эффекта суммации [4].

Для оценки эффектов суммации был использован коэффициент комбинированного действия (далее - ККД) для химических веществ, входящих в состав выбросов предприятия $[1,6,10]$.

При оценке степени загрязнения атмосферного воздуха с использованием ККД в районе расположения предприятия были определены 11 групп суммации, в 4 из которых имеются превышения нормативного значения ККД (табл. 4).
Для перечня веществ, выбрасываемых предприятием, был рассчитан индекс опасности при рефлекторном и хроническом воздействии с учетом критических органов и систем, поражаемых веществами, находящимися в смеси (табл. 5) [7].

Наибольшие значения индекса опасности (высокий) отмечаются для органов дыхания на границе площадки предприятия как при рефлекторном, так и при хроническом воздействии и в жилой зоне при рефлекторном воздействии (см. табл. 5).

Выводы. В Республике Беларусь предприятия, выбросы которых вносят наибольший вклад в формирование загрязнения атмосферного воздуха, относятся к отраслям транспорта и связи, пищевой и химической промышленности, сельскому хозяйству. Данные отрасли являются наиболее активно развивающимися. В структуре выбросов предприятий наиболее приоритетными загрязнителями являются оксиды азота, аммиак, диоксид серы, монооксид углерода, твердые частицы различных фракций, тяжелые металлы (ртуть, свинец, кадмий), а также летучие органические соединения. Характеристики выбросов и отраслевая принадлежность исследуемого предприятия отражают республиканские тенденции. 
Индекс опасности при рефлекторном и хроническом воздействии веществ, выбрасываемых объектом

\begin{tabular}{|c|c|c|c|c|c|c|}
\hline \multirow{2}{*}{$\begin{array}{c}\text { Критические } \\
\text { органы и системы }\end{array}$} & \multicolumn{2}{|c|}{$\begin{array}{c}\text { Граница площадки } \\
\text { предприятия } \\
\end{array}$} & \multicolumn{2}{|c|}{$\begin{array}{l}\text { Жилая зона (130-150 м от гра- } \\
\text { ницы площадки предприятия) }\end{array}$} & \multicolumn{2}{|c|}{$\begin{array}{c}210 \text { м от границы } \\
\text { площадки предприятия }\end{array}$} \\
\hline & $\begin{array}{c}\text { Рефлекторное } \\
\text { воздействие }\end{array}$ & $\begin{array}{l}\text { Хроническое } \\
\text { воздействие }\end{array}$ & $\begin{array}{c}\text { Рефлекторное } \\
\text { воздействие }\end{array}$ & $\begin{array}{l}\text { Хроническое } \\
\text { воздействие }\end{array}$ & $\begin{array}{c}\text { Рефлекторное } \\
\text { воздействие }\end{array}$ & $\begin{array}{l}\text { Хроническое } \\
\text { воздействие }\end{array}$ \\
\hline Органы дыхания & 9,27 & 6,34 & 6,67 & 3,33 & 4,8 & 3,61 \\
\hline Центральная нервная система & 2,9 & 4,82 & 1,32 & 2,22 & 1,18 & 2,60 \\
\hline Слизистые & 1,24 & 0,23 & 0,71 & 0,06 & 0,63 & 0,06 \\
\hline Развитие & 1,22 & 1,23 & 1,05 & 0,84 & 0,94 & 0,92 \\
\hline Иммунная система & 0,69 & 1,34 & 0,56 & 1,17 & 0,46 & 1,49 \\
\hline Репродуктивная система & 0,69 & 0,81 & 0,56 & 0,45 & 0,46 & 0,46 \\
\hline Желудочно-кишечный тракт & 0,24 & 0,33 & 0,02 & 0,08 & 0,01 & 0,05 \\
\hline Кровь & 0,09 & 1,43 & 0,02 & 1,06 & 0,02 & 1,18 \\
\hline Сердечно-сосудистая система & 0 & 1,05 & 0 & 0,73 & 0 & 0,91 \\
\hline
\end{tabular}

Максимальные изолированные значения риска от выбрасываемых предприятием веществ получены для углеводородов предельных алифатического ряда $\mathrm{C}_{11}-\mathrm{C}_{19}$ и находятся на уровне удовлетворительного риска при рефлекторном действии и вызывающего опасения - при хроническом. Комбинированный риск от всех выбрасываемых веществ при рефлекторном действии определяется на уровне удовлетворительного, при хроническом - на уровне опасного. Получены высокие значения индекса опасности для системы органов дыхания: при хроническом действии - 6,34, при рефлекторном - 9,27.
Приведенные материалы свидетельствуют в пользу необходимости учета комбинированного действия и эффектов суммации химических веществ при принятии градостроительных решений и корректировке размеров С 33 , что наилучшим образом реализуется через процедуру оценки риска. Полученные при осуществлении процедуры оценки риска данные (значения комбинированного риска, индекса опасности и ККД) также позволяют выявить возможные неблагоприятные эффекты со стороны состояния здоровья населения, определить направления эпидемиологических исследований, разработать профилактические мероприятия по защите здоровья населения [14].

\section{Список литературы}

1. Гигиенический норматив содержания загрязняющих химических веществ в атмосферном воздухе, обладающих эффектом суммации: гигиенический норматив / утв. постановлением Министерства здравоохранения Республики Беларусь № 33 от 30.03.2015 г. - Введ. с 30.03.2015 г. [Электронный ресурc]. - URL: http: //minzdrav.gov.by/dadvfiles/000352_158798_gig_normativ_33.doc (дата обращения: 11.05.2015).

2. Методика оценки риска здоровью населения факторов среды обитания: инструкция по применению / утв. заместителем министра здравоохранения Республики Беларусь рег. № 025-1211 от 08.06.2012 г. - Введ. с 08.06.2012 г. [Электронный pecypc]. - URL: med.by/methods/pdf/025-1211.pdf (дата обращения: 11.05.2015).

3. Методические подходы к оценке результативности и экономической эффективности рискориентированной контрольно-надзорной деятельности Роспотребнадзора / Н.В. Зайцева, И.В. Май, И.В. Шур, Д.А. Кирьянов // Анализ риска здоровью. - 2014. - № 1. - С. 7-9.

4. Оценка риска для здоровья населения от воздействия химических веществ, загрязняющих атмосферный воздуха: инструкция 2.1.6.11-9-29-2004 / утв. постановлением главного государственного санитарного врача Республики Беларусь № 63 от 05.07.2004 г. - Введ. с 05.07.2004 г. [Электронный ресурc]. - URL: med.by/methods/pdf/2.1.6.11-9-29-2004.pdf (дата обращения: 11.05.2015).

5. Охрана окружающей среды в Республике Беларусь: стат. сб. / Нац. стат. ком. Республики Беларусь; редкол. И.А. Костевич [и др.]. - Минск, 2013. - 255 с.

6. Пинигин М.А. Теория и практика оценки комбинированного действия химического загрязнения атмосферного воздуха // Гигиена и санитария. - 2001. - № 1. - С. 9-13.

7. Р 2.1.10.1920-04. Руководство по оценке риска для здоровья населения при воздействии химических веществ, загрязняющих окружающей среды. - М.: Федеральный центр Госсанэпиднадзора Минздрава России, 2004. - 143 с.

8. Состояние природной среды Беларуси: экол.бюл. 2012 г. / под ред. В.Ф. Логинова. - Минск, 2013. $383 \mathrm{c}$. 
9. Требования к организации санитарно-защитных зон предприятий, сооружений и иных объектов, являющихся объектами воздействия, на здоровье человека и окружающую среду: санитарные нормы и правила / утв. постановлением Министерства здравоохранения Республики Беларусь № 35 от 15.05.2014 г.Введ. с 15.05.2014 г. [Электронный ресурс]. - URL: http: //minzdrav.gov.by/ru/static/acts/tehnicheskie/teksty/obschie_voprosy (дата обращения: 11.05.2015).

10. Филонов В.П., Соколов С.М., Науменко Т.Е. Эколого-эпидемиологическая оценка риска для здоровья человека качества атмосферы. - Минск: ТРАНСТЭКС, 2001. - 187 с.

11. Air quality and health: WHO Fact sheet $N^{\circ} 313$, Updated September 2011 [Электронный peсурс]. URL: http: //www.who.int/mediacentre/factsheets/fs313/en/ (дата обращения: 26.12.2013).

12. Environment and health in the WHO European Region: progress, challenges and lessons learned: working document: $65^{\text {th }}$ session Regional Committee for Europe 17.07.2015, № 150478. [Электронный pecypc]. - URL: http: //www.euro.who.int/_data/assets/pdf_file/0018/283041/65wd11e_EnvironmentHealth_150478.pdf? ua=1 (дата обращения: 13.08.2015).

13. Exploring the joint effect of atmospheric pollution and socioeconomic status on selected health outcomes: an overview of the PAISARC project / D. Bard, O. Laurent., L. Filleul, S. Havard, S. Deguen, C. Segala, G. Pedrono, E. Rivi ere, C. Schillinger, L. Rou“ 11, D. Arveiler and D. Eilstein // Environmental research letters. 2007. - Vol. 2, № 4. - P. 215-239.

14. Progress report on the European Environment and Health Process: working document: $65^{\text {th }}$ session Regional Committee for Europe 28.07.2015, № 150476. [Электронный pecypc]. - URL: http: //www.euro.who.int/_data/assets/pdf_file/0006/283839/65wd18e_EHP_150476.pdf? uа=1 (дата обращения: 13.08.2015).

\section{References}

1. Gigienicheskij normativ soderzhanija zagrjaznjajushhih himicheskih veshhestv v atmosfernom vozduhe, obladajushhih jeffektom summacii: gigienicheskij normativ: utv. postanovleniem Ministra zdravoohranenija Respubliki Belarus' 30.03.2015, № 33. Vved. s 30.03.2015 [Sanitary-hygienic standard of content of chemical pollutants in atmosphere air, with the effect of summation: hygienic norm: approv. by the Decree of the Minister of Health of the Republic of Belarus 30.03.2015, No. 33. Introd. from 03.30.2015]. Available at: http: //minzdrav.gov.by/dadvfiles/000352_158798_gig_normativ_33.doc.

2. Metodika ocenki riska zdōov'ju naselenija faktorov sredy obitanija: instrukcija po primeneniju: utv. Zamestitelem Ministra zdravoohranenija Respubliki Belarus' 08.06.2012, reg. № 025-1211. Vved. s 08.06.2012 [Methodology of risk assessment to public health of environmental habitat factors: Guideline: approv. by Deputy Minister of Public Health of the Republic of Belarus 08.06.2012, reg. No. 025-1211. Introd. from 08.06.2012]. Available at: med.by/methods/pdf/025-1211.pdf.

3. Zaitseva N.V., May I.V., Shur P.Z., Kiryanov D.A. Metodicheskie podhody k ocenke rezul'tativnosti i jekonomicheskoj jeffektivnosti risk-orientirovannoj kontrol'no-nadzornoj dejatel'nosti rospotrebnadzora [Methodological approaches to assessment of productivity and economic effectiveness of risk-oriented control and supervisory activities of Rospotrebnadzor]. Analiz riska zdorov'ju, 2014, no. 1, pp. 7-9.

4. Ocenka riska dlja zdorov'ja naselenija ot vozdejstvija himicheskih veshhestv, zagrjaznjajushhih atmosfernyj vozduha: instrukcija 2.1.6.11-9-29-2004: utv. postanovleniem Glavnogo gosudarstvennogo sanitarnogo vracha Resp. Belarus' 05.07.2004, № 63. Vved. s 05.07.2004 [Risk assessment to human health from influence of chemicals, polluting atmosphere air: guideline 2.1.6.11-9-29-2004: approv. by the Decree of Chief State Sanitary Doctor of the Rep. of Belarus 05.07.2004, No. 63. Introd. from 05.07.2004]. Available at: med.by/methods/pdf/2.1.6.11-929-2004.pdf.

5. Ohrana okruzhajushhej sredy v Respublike Belarus': statisticheskij sbornik [Environmental protection in the Republic of Belarus: statistical book]. Nacional'nyj statisticheskij komitet Respubliki Belarus'. Minsk, 2013. 255 p.

6. Pinigin M.A. Teorija i praktika ocenki kombinirovannogo dejstvija himicheskogo zagrjaznenija atmosfernogo vozduha [Theory and practice of combined action assessment of chemical air pollution]. Gigiena $i$ sanitarija, 2001, no. 1, pp. 9-13.

7. Rukovodstvo po ocenke riska dlja zdorov'ja naselenija pri vozdejstvii himicheskih veshhestv, zagrjaznjajushhih okruzhajushhej sredy R 2.1.10.1920-04 [Guideline of risk assessment to public health under the influence of chemicals polluting the environment P 2.1.10.1920-04]. Moscow: Federal'nyj centr Gossanjepidnadzora Minzdrava Rossii, 2004. 143 p.

8. Sostojanie prirodnoj sredy Belarusi: jekologicheskij bjulleten' 2012 g. [Status of environment in Belarus: ecological bulletin 2012.]. Pod red. V.F. Loginova. Minsk, 2013. 383 p.

9. Trebovanija k organizacii sanitarno-zashhitnyh zon predprijatij, sooruzhenij i inyh ob\#ektov, javljajushhihsja ob\#ektami vozdejstvija na zdorov'e cheloveka i okruzhajushhuju sredu: sanitarnye normy i pravila: utv. postanovleniem Ministra zdravoohranenija Respubliki Belarus' 15.05.2014, № 35. Vved. s 15.05.2014 [Require- 
ments to organization of sanitary protection zones of enterprises, buildings and other facilities that are subjects of influence on human health and environment: sanitary norms and rules: approv. by the Decree of the Minister of Health of the Republic of Belarus 15.05.2014, No. 35. Introduced from 05.15.2014]. Available at: http: //minzdrav.gov.by/ru/static/acts/tehnicheskie/teksty/obschie_voprosy.

10. Filonov V.P., Sokolov S.M., Naumenko T.E. Jekologo-jepidemiologicheskaja ocenka riska dlja zdorov'ja cheloveka kachestva atmosfery [Ecological and epidemiological assessment of health risk to human health of air quality]. Minsk: TRANSTJeKS, 2001. 187 p.

11. Air quality and health: WHO Fact sheet $N^{\circ} 313$, Updated September 2011. Available at: http: //www.who.int/mediacentre/factsheets/fs313/en/.

12. Environment and health in the WHO European Region: progress, challenges and lessons learned: working document: 65th session Regional Committee for Europe 17.07.2015, № 150478. Available at: http: //www.euro.who.int/_data/assets/pdf_file/0018/283041/65wd11e_EnvironmentHealth_150478.pdf? ua=1.

13. Bard D., Laurent O., Filleul L., Havard S. and so on. Exploring the joint effect of atmospheric pollution and socioeconomic status on selected health outcomes: an overview of the PAISARC project. Environmental research letters, 2007, vol. 2, no. 4. pp. 215-239.

14. Progress report on the European Environment and Health Process: working document: 65th session Regional Committee for Europe 28.07.2015, № 150476. Available at: http: //www.euro.who.int/_data/assets/pdf_file/0006/283839/65wd18e_EHP_150476.pdf? ua=1.

\title{
HYGIENIC ASSESSMENT OF IMPACT ON PUBLIC HEALTH AIR POLLUTION IN VIEW OF THE COMBINED ACTIONS OF CHEMICALS IN THE AREA OF THE CHEMICAL INDUSTRY
}

\author{
L.M. Shevchuk ${ }^{1}$, N.A. Tolkacheva ${ }^{2}$, A.E. Pshegroda ${ }^{1}$, I.P. Semenov ${ }^{2}$ \\ ${ }^{1}$ Republican Unitary Enterprise "Scientific and Practical Center of Hygiene", Republic of Belarus, Minsk, \\ 8 Akademicheskaya St., 220012 \\ ${ }^{2}$ EI “Belarusian State Medical University”, Republic of Belarus, Minsk, 83 Dzerzhinsky Pr., 220016
}

The article presents the results of air pollution study in the area of chemical industry. The results of evaluating possible impact of chemical pollution on the population health are reflected by the parameter values: complex indicator " $R$ " public health risk (reflexive, chronic, and combined risk at the reflexive and chronic action), hazard index and combined action coefficient. The comparative characteristic of the received data is provided by the degree of air pollution during the evaluation, taking into account the combined effect of chemicals and during the evaluation without the combined action of chemicals. The possibility of using the results to predict the changes in the population health status and to plan epidemiological studies is determined.

Key words: atmosphere chemical pollution, combined action of chemicals, combined risk of chemicals, combined action coefficient.

(c) Shevchuk L.M., Tolkacheva N.A., Pshegroda A.E., Semenov I.P., 2015

Shevchuk Larisa Mikhailovna - Candidate of Medicine, Associate Professor, Deputy Director for Research (e-mail: sheuchuklm@mail.ru; tel. +375 17 292-50-15).

Tolkacheva Nadezhda Andreevna - Assistant of the Department of Occupational Health in Educational Institution "Belarusian State Medical University", 83, Dzerzhinsky Pr., Minsk, Republic of Belarus, 220016 (e-mail: gt@bsmu.by; tel. 17375 365-84 -43).

Pshegroda Aleksandr Evgenyevich - Senior Researcher at the Laboratory of Environmental Factors and Health Risk Analysis Technologies (e-mail: risk.factors@ rspch.by; tel. +375 17 292-47-00).

Semenov Igor Pavlovich - Candidate of Medicine, Associate Professor, Head of the Department of Occupational Health (e-mail: gt@bsmu.by; tel. + 375 17 365-84-43). 


\title{
ОЦЕНКА И УПРАВЛЕНИЕ РИСКАМИ В МЕДИЦИНЕ ТРУДА
}

УДК 613.6.027: 63.321.933

\section{ПРОФЕССИОНАЛЬНЫЙ РИСК РАЗВИТИЯ ЗАБОЛЕВАНИЙ ПЕРИФЕРИЧЕСКОЙ НЕРВНОЙ СИСТЕМЫ У ТРАКТОРИСТОВ- МАШИНИСТОВ СЕЛЬСКОХОЗЯЙСТВЕННОГО ПРОИЗВОДСТВА}

\author{
Г.А. Безрукова, Т.А. Новикова, М.Л. Шалашова, С.С. Райкин \\ ФБУН «Саратовский научно-исследовательский институт сельской гигиены» Федеральной службы \\ по надзору защиты прав и благополучия человека, Россия, 410022, г.Саратов, ул. Заречная, 1А
}

\begin{abstract}
На основе результатов гигиенической оченки условий труда на отечественной сельскохозяйственной технике старых и новых образиов при выполнении основных видов сезонных полевых работ в течение годового производственного ичикла и анализа нозологической структуры накопленной профзаболеваемости работников сельского хозяйства Саратовской области за период с 2004 по 2014 г. дана оценка профессионального риска развития заболеваний периферической нервной системы у трактористов-машинистов сельскохозяйственного производства. Проведенная в соответствии методикой, изложенной в Р 2.2.1766-03, оченка профессионального риска показала, что категория априорного риска их здоровью в течение годового производственного иикла колебалась от высокого до очень высокого (непереносимого). Выявлено, что наиболее значимыми факторами вредных условий труда при работе на сельскохозяйственной технике, которые способны выступать в роли триггеров при формировании вертеброгенных заболеваний периферической нервной системы, являются общая и локальная вибрачия, неблагоприятные микроклиматические условия, длительная неудобная статичная рабочая поза и физическое перенапряжение. Риск развития заболеваний периферической нервной системы у механизаторов сельского хозяйства был отнесен к высокой категории с индексом профессиональных заболеваний (Ипз) равным 0,5\%.

Ключевые слова: трактористы-машинисты сельскохозяйственного производства, вредные факторы производственной среды и трудового процесса, профессиональные заболевания периферической нервной системы.
\end{abstract}

В настоящее время в силу высокой распространенности проблема боли в спине приобретает характер неинфекционной эпидемии, поскольку в течение жизни от нее страдают от 34 до $82 \%$ населения развитых и развивающихся стран мира, пик заболеваемости приходится на возраст от 30 до 60 лет, а денежные затраты на лечение дорсалгий, по данным ВОЗ, в три раза превышают затраты на лечение онкологических больных [12]. В России эта патология дает от 20 до $80 \%$ случаев временной нетрудоспособности в социально активной популяции и $20,4 \%$ в общей структуре инвалидности при дегенеративных заболеваниях костно-суставной системы $[2,7]$.
По данным эпидемиологических исследований синдром боли в спине широко распространен среди трудоспособного сельского населения. Причем из-за ограниченной доступности специализированной медицинской помощи в силу удаленности большинства сельских поселений от медицинских организаций и низкой мобильности жителей села, нежелания или невозможности прерывания трудовой деятельности, а также отсутствия целенаправленной активной выявляемости заболеваний периферической нервной системы во время обязательных медицинских осмотров фактические значения заболеваемости работников сельского хозяйства превышают уровень, за-

(C) Безрукова Г.А., Новикова Т.А., Шалашова М.Л., Райкин С.С., 2015

Безрукова Галина Александровна - доктор медицинских наук, доцент, главный научный сотрудник (e-mail: bezrukovagala@yandex.ru; тел. (845-2) 92-78-90).

Новикова Тамара Анатольевна - кандидат биологических наук, доцент, руководитель лаборатории гигиены труда в сельском хозяйстве и перерабатывающей промышленности (e-mail: niisgsar@rol.ru; тел. +7 (8452) 92-27-68).

Шалашова Мария Леонтьевна - врач клинки профзаболеваний (e-mail: niisgsar@rol.ru; тел. +7 (8452) 92-27-68).

Райкин Сергей Сергеевич - младший научный сотрудник лаб. гигиены труда в сельском хозяйстве и перерабатывающей промышленности (e-mail: niisgsar@rol.ru; тел. +7 (8452) 92-27-68). 
регистрированный по данным обращаемости за медицинской помощью, в 1,7 раза [11].

Заболевания костно-мышечной системы имеют сложную полиэтиологическую природу; в их формировании могут принимать участие различные факторы: биомеханический, инволюционный, наследственный, аномалии развития, гормональный, сосудистый (гипоксический), аутоиммунный, а также неблагоприятные условия окружающей среды, провоцирующие возникновение и обострение течения синдрома боли в спине [8].

С позиций медицины труда наибольшего внимания заслуживает гигиеническая оценка влияния факторов производственной среды и трудового процесса на патогенез и клиническую манифестацию этой широко распространенной патологии.

Согласно современным представлениям $[3,4,9]$, факторами риска развития профессиональных заболеваний периферической нервной системы могут являться:

- физическое перенапряжение (тяжесть трудового процесса): подъем и перемещение тяжестей или постоянная нагрузка на позвоночник, выполнение однообразных, часто повторяющихся движений при наклонах и поворотах туловища, длительная вынужденная рабочая поза;

- общая и локальная вибрация, особенно в сочетании с физическим напряжением;

- неблагоприятные метео- и мироклиматические условия (повышенная влажность, воздействие конвекционного и лучистого тепла, резкие колебания температуры на рабочем месте);

- повышенные уровни шума;

- хронический стресс;

- загрязнение воздуха рабочей зоны токсичными химическими соединениями.

В настоящее время в общей структуре профзаболеваемости, регистрируемой на территории Российской Федерации, вертеброгенные заболевания периферической нервной системы, в основном рефлекторные и компрессионные синдромы шейного и пояснично-крестцового уровней, связанные с функциональным перенапряжением, занимают одно из первых ранговых мест (до $54 \%$ случаев выявляемой профпатологии в отдельных отраслях экономики) и поражают в основном мужчин в возрасте до 45 лет [6].

Трактористы-машинисты сельскохозяйственного производства (механизаторы сельского хозяйства) являются наиболее квалифицированной профессиональной группой аграрного сектора, а их условия труда определяются, главным образом, техническими характеристиками и состоянием используемого машинотракторного парка, который в настоящее время на 60-75\% состоит из морально устаревшей и физически изношенной техники старых образцов [5]. При эксплуатации сельскохозяйственной техники механизаторы сельского хозяйства в той или иной степени подвергаются воздействию практически всех вышеперечисленных вредных производственных факторов, способных выступать в роли триггеров при формировании вертеброгенных заболеваний периферической нервной системы [1].

Целью настоящего исследования являлась оценка профессионального риска развития заболеваний периферической нервной системы у трактористов-машинистов сельскохозяйственного производства на основе комплексной гигиенической характеристики условий труда, уровня и структуры профессиональной заболеваемости.

Материалы и методы. Нами были исследованы условия труда при работе на сельскохозяйственной технике, наиболее широко эксплуатируемой в настоящее время сельхозпредприятиями Саратовской области - тракторах старых (ДТ-75, ДТ-75Н, ДТ-75С, К-700, К-701А, ВТ-100 «Волгарь», МТ3-80) и новых образцов («Белорус 1523») и зерноуборочных комбайнах старого (СК-5М «Нива», СК-5МЭ-1 «НиваЭффект», РСМ-10 «Дон-1200» и РСМ-10 «Дон1500») и нового поколения - PCM-101 «VECTOR» и PCM-142 «ACROS».

Условия труда оценивались с использованием общепринятых в гигиене труда методов и оборудования. Классификация факторов рабочей среды и трудового процесса проводилась согласно Р. 2.2.2006-05 «Руководство по гигиенической оценке факторов рабочей среды и трудового процесса. Критерии и классификация условий труда». Оценка риска здоровью осуществлена в соответствии методикой, изложенной в Р 2.2.1766-03 «Руководство по оценке профессионального риска для здоровья работников. Организационно-методические основы, принципы и критерии оценки». Были изучены параметры микроклимата, уровни шума, общей и локальной вибрации, загрязненности воздуха рабочей зоны аэрозолями преимущественно фиброгенного действия (АПФД) и вредными химическими вредными веществами, тяжесть и напряженность трудового процесса при выполнении основных видов сезонных полевых работ во время годового производственного цикла. 
Факторный и структурный анализ профессиональной заболеваемости механизаторов сельского хозяйства выполнен на основе данных клиники профессиональных заболеваний ФБУН «Саратовский НИИСГ» Роспотребнадзора и статистических материалов Управления Роспотребнадзора по Саратовской области, сформированных по форме № 389-1/y-01 «Карта учета профессионального заболевания (отравления)» за период с 2004 по 2014 г.

Статистическая обработка данных проведена с использованием программных приложений Mcrosoft Office-2007 (MS Excel-07) и программы Statistica 10.0.

Результаты и их обсуждение. Анализ результатов исследования показал, что наиболее значимыми факторами, формирующими вредные условия труда механизаторов сельского хозяйства, были повышенные уровни шума и вибрации, запыленность воздуха рабочей зоны, неблагоприятные микроклиматические условия в кабинах, выраженность которых зависела от вида выполняемых работ, марки и срока эксплуатации мобильной сельхозтехники.

Источниками шума на тракторах являются работающий двигатель, передаточные механизмы, ходовая система и система выхлопа отработанных газов. Результаты проведенных исследований свидетельствовали о превышении ПДУ шума на рабочих местах в кабинах всех моделей и марок обследованных тракторов. Частотный анализ уровней звукового давления показал, что по своему характеру шум был широкополосный, с превышением ПДУ на 1 - 18 дБА в кабинах техники старых образцов при всех видах полевых работ. Наиболее высокие уровни звука (до 98,0 2,4 дБА) зарегистрированы в кабинах гусеничных тракторов ДТ-75 и ДТ-75С при севе зерновых культур. Наименьшие - на рабочем месте тракториста «Белорус 1523» при транспортных работах.

При исследовании уровня шума в кабинах зерноуборочных комбайнов установлено, что только новые марки PCM-142 «ACROS» и PCM-101 «Вектор» имеют шумовые характеристики, близкие к допустимым. На старой технике (СК-5 «Нива», «Дон-1200», «Дон-1500»), наиболее широко эксплуатируемой в настоящее время в сельском хозяйстве, обнаружены превышения ПДУ от 5 до 15 дБА. Так, при уборке зерновых культур в кабинах зерноуборочных комбайнов старого образца СК-5М «Нива» отмечались уровни звука (до $88,0 \pm 3,3$ дБА). Частотный анализ уровней звукового давления по- казал, что по своему характеру шум был широкополосный, с превышением ПДУ как на низких, так и на высоких частотах.

Общая вибрация на рабочих местах в кабинах сельскохозяйственной техники является переменной по уровню и передается через сиденье, с наибольшей интенсивностью в вертикальном направлении. Вибрация локальная передается через органы управления на руки и ноги механизатора.

Общая вибрация в кабинах исследуемой мобильной сельскохозяйственной техники представляла широкополосные процессы со спектром, охватывающим 1-250 Гц с превышением ПДУ до 6 дБ. В кабинах тракторов превышение допустимых уровней общей вибрации выявлено на среднегеометрических частотах 4-16 Гц, зерноуборочных комбайнов - на частотах 4,0-31,5 Гц. Наибольшее превышение ПДУ локальной вибрации (до 5 дБ) было зарегистрировано на рычагах гусеничных тракторов ДТ-75С при севе зерновых и на рулевом колесе тракторов К-700 и К-701А при выполнении пахотных работ.

При сравнительном анализе виброакустических параметров установлено возрастание их уровней при увеличении срока эксплуатации техники. Так, уровни шума и общей вибрации в кабинах техники со сроком эксплуатации более 10 лет были выше на 2-6 дБА и 2-5 дБ соответственно, чем при сроке эксплуатации от 5 до 10 лет. На новых зерноуборочных комбайнах PCM-101 «VECTOR» и PCM-142 «ACROS» уровни шума, общей и локальной вибрации не превышали ПДУ. Однако при эксплуатации PCM-101 «VECTOR» в течение 5 лет и более отмечалось повышение уровней звука на 5 дБА.

Все полевые работы сопровождались выделением пыли различной интенсивности, зависящей от вида выполняемой деятельности, эффективности работы средств очистки воздуха, метеоусловий, скорости и направления движения агрегата. Основным источником пыли при сельскохозяйственных работах служили ходовая система техники и прицепные или навесные сельскохозяйственные орудия. Попадая в кабину через неплотности в полу, дверях и окнах, а также нагнетаясь приточными вентиляторами, пыль витает в воздухе и оседает на одежде работающих, полу кабины и других поверхностях рабочего места, способствуя поддержанию постоянной запыленности воздуха рабочей зоны. 
Согласно полученным данным, пыль, содержащаяся в воздухе кабин тракторов, на 76-94 \% являлась почвенной, остальная часть органическая, состоящая из растительных остатков (семена, пыльца, частицы измельченных растений). Пыль, образующаяся при работе зерноуборочного комбайна, была по своему составу смешанная (68-83\% органических частиц, 32-17\% - минеральная часть). Содержание свободной двуокиси кремния в пыли, обнаруженной в кабинах тракторов и зерноуборочных комбайнов, не превышало $10 \%$.

Наибольшая концентрация пыли в кабинах тракторов обнаруживалась при бороновании $\left(32,1 \pm 2,4 \mathrm{Mr} / \mathrm{M}^{3}\right)$ и севе зерновых $\left(34,2 \pm 2,8 \mathrm{мг} / \mathrm{M}^{3}\right)$. При уборке зерновых наибольшие концентрации пыли отмечены в воздухе кабин комбайнов старых марок СК-5M1 и СК-5, оборудованных малоэффективными средствами очистки воздуха $\left(33,5 \pm 3,1 \mathrm{мг} / \mathrm{M}^{3}\right)$. В кабинах зерноуборочных комбайнов новых образцов PCM-101 «VECTOR» и PCM-142 «ACROS», оснащенных кондиционерами, концентрации пыли были ниже ПДК $\left(0,14 \pm 0,8 \mathrm{мг} / \mathrm{M}^{3}\right)$.

Воздух рабочей зоны в кабинах сельскохозяйственной техники старых образцов был загрязнен не только пылью, но и компонентами выхлопных газов (оксидами углерода, оксидами азота, акролеином), содержание которых не превышало ПДК.

Параметры микроклимата в кабинах тракторов обследованных марок (температура, влажность, скорость движения воздуха, тепловая нагрузка среды) имели выраженные сезонные изменения и в значительной степени определялись наличием и эффективностью работы средств нормализации микроклимата, целостностью герметизации и термоизоляции кабин. Основными источниками тепла в кабинах являлись солнечная радиация (70-80\%), работающий двигатель и нагретые поверхности кабин.

В теплый период года температура воздуха в кабинах техники старых образцов, оборудованных малоэффективными вентиляционными установками, значительно превышала допустимые пределы, и механизаторы для ее снижения были вынуждены работать с открытыми окнами и дверями, что приводило к повышению запыленности воздуха. В кабинах гусеничных тракторов старых марок ДТ-75, ДТ-75Н, ВТ-100, не оборудованных кондиционерами, максимальная температура воздуха в период сева зерновых достигала $+39,0^{\circ} \mathrm{C}$ при температуре наружного воздуха $+26,4 \pm 0,89{ }^{\circ} \mathrm{C}$.
В кабинах зерноуборочных комбайнов старых марок СК-5М «Нива» и РСМ-10 «Дон 1500» со сроком эксплуатации от 5 до 10 лет при неработающих средствах нормализации микроклимата температура воздуха могла превышать наружную до $10^{\circ} \mathrm{C}$. Внутренние поверхности кабин нагревались до $+45^{\circ} \mathrm{C}$, что усиливало микроклиматический дискомфорт. Относительная влажность воздуха колебалась в пределах 45-90\% и в значительной степени зависела от типа средств нормализации микроклимата. Состояние воздушной среды в кабинах зерноуборочных комбайнов новых марок РCM-101 «VECTOR» и PCM-142 «ACROS» по параметрам микроклимата при работающих кондиционерах соответствовало гигиеническим нормативам.

В холодный период года в кабинах тракторов формировался охлаждающий микроклимат, когда температура воздуха была ниже допустимой (менее $+14^{\circ} \mathrm{C}$ ). Особенно низкий уровень температуры зарегистрирован в кабинах тракторов ДТ-75 при снегозадержании.

Трудовая деятельность механизаторов на сельскохозяйственной технике протекала в условиях длительного поддержания статичной рабочей позы (до 80 \% смены) на фоне ограниченной общей подвижности тела. На технике старых марок формировалась неудобная рабочая поза с периодическими глубокими наклонами корпуса вперед и статическими физическими нагрузками, обусловленными нерациональной организацией рабочих мест и чрезмерными усилиями, прилагаемыми к органам управления при их переключении. На новой технике (зерноуборочных комбайнах РСМ-101 и РСМ-142), оборудованных кабинами, отвечающими эргономическим требованиям, органы управления и контроля были в пределах сенсомоторной зоны, что обеспечивало работу в более удобной рабочей позе. Однако длительное нахождение в статичной рабочей позе сохранялось, формируя тяжелые условия труда 2-й степени (класс 3.2).

Результаты исследований напряженности трудового процесса показали, что трудовая деятельность механизаторов характеризовалась напряженностью функций внимания, зрительного и слухового анализатора, связанных с необходимостью точного вождения агрегата (особенно при посеве и уборке зерновых) и восприятия дифференцированных сигналов на фоне выраженных шумовых помех. Для механизаторов было характерно нервно-эмоциональное напряжение, обусловленное сжатыми сроками выполнения полевых работ, нарушениями в организа- 
Гигиеническая оценка условий труда механизаторов при выполнении основных видов сезонных полевых работ

\begin{tabular}{|l|c|c|c|c|c|c|}
\hline \multirow{2}{*}{\begin{tabular}{c}
\multirow{2}{*}{$\begin{array}{c}\text { Наименование } \\
\text { фактора }\end{array}$} \\
\cline { 2 - 7 }
\end{tabular}} & $\begin{array}{c}\text { Предпосевная } \\
\text { обработка почвы }\end{array}$ & \multirow{2}{*}{ Посев зерна } & \multirow{2}{*}{ Уборка зерна } & \multicolumn{2}{c|}{ Пахотные работы } & $\begin{array}{c}\text { Снегоза- } \\
\text { держание }\end{array}$ \\
\cline { 5 - 7 } & $3.1-3.2$ & $3.1-3.4$ & $2 *-3.4$ & $2 *-3.4$ & 2 & $2-3.2$ \\
\hline Микроклимат & $3.1-3.3$ & $3.1-3.3$ & $2 *-3.3$ & $3.1-3.3$ & 3.1 & - \\
\hline АПФД & 2 & 2 & 2 & 2 & 2 & 2 \\
\hline Загазованность & $3.1-3.3$ & $3.1-3.3$ & $2 *-3.2$ & $3.1-3.2$ & 3.2 & 3.2 \\
\hline Шум & 3.1 & 3.1 & $2 *-3.1$ & $2-3.1$ & $2-3.2$ & 3.1 \\
\hline Вибрация общая & $3.1-3.2$ & $3.1-3.2$ & $2 *-3.1$ & $2 *-3.2$ & $2 *-3.2$ & 3.1 \\
\hline Вибрация локальная & 3.2 & 3.2 & 3.2 & 3.2 & 3.2 & 3.2 \\
\hline Тяжесть труда & 3.2 & 3.2 & 3.2 & 3.2 & 3.2 & 3.2 \\
\hline Напряженность труда & $\mathbf{3 . 4}$ & $\mathbf{3 . 4}$ & $\mathbf{3 . 3 - 3 . 4}$ & $\mathbf{3 . 3}-\mathbf{3 . 4}$ & $\mathbf{3 . 3}$ & $\mathbf{3 . 3}$ \\
\hline Общая оценка & & & & & \\
\hline
\end{tabular}

П р и м е ч а н и е : * - в кабинах отечественной техники новых моделей со сроком эксплуатации не боле трех лет.

ции труда, техническими неполадками машин и, нередко, нестабильными погодными условиями. При этом продолжительность рабочей смены механизаторов в период срочных сельскохозяйственных работ (посев, уборка) могла составлять 12 часов и более.

С учетом всего комплекса полученных данных выполнена общая гигиеническая оценка условий труда при осуществлении основных видов сезонных полевых работ, позволившая классифицировать условия труда на обследованной технике как вредные (классы 3.3-3.4), в зависимости от выполняемых полевых работ, вида и марки техники и срока ее эксплуатации (таблица).

Таким образом, при работе на мобильной сельскохозяйственной технике старых образцов механизаторы сельского хозяйства подвергались воздействию более широкого спектра вредных производственных факторов (физическое перенапряжение, повышенные уровни вибрации, неблагоприятный микроклимат), способных выступать в роли триггеров при формировании вертеброгенных заболеваний периферической нервной системы, чем на более современных моделях тракторов и зерноуборочных комбайнов, при эксплуатации которых риск развития заболеваний костно-мышечной системы был, в основном, связан с физическим перенапряжением, обусловленным длительным нахождением в статичной фиксированной рабочей позе.

Проведенная в соответствии методикой, изложенной в Р 2.2.1766-03, оценка профессионального риска показала, что категория априорного профессионального риска для здоровья механизаторов в течение годового производственного цикла колебалась от высокого до очень высокого (непереносимого).
Анализ профессиональной заболеваемости механизаторов сельского хозяйства, зарегистрированной на территории Саратовской области за период с 2004 по 2014 г., выявил 415 больных, страдающих 662 профессиональными заболеваниями (ПЗ). Несмотря на более чем двукратное снижение за период наблюдения численности работающих в данной профессии (с 13086 до 6031 чел.), уровень профзаболеваемости среди этой профессиональной группы оставался стабильно повышенным по сравнению с общеотраслевой (1,52-5,85 на 10000 работающих в сельском хозяйстве РФ), составляя по разным годам наблюдения от 25,2 до 56,7 на 10000 механизаторов.

Средний возраст механизаторов сельского хозяйства с первично установленным диагнозом

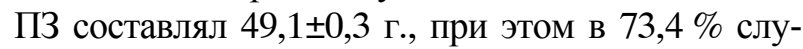
чаев ПЗ развивались у лиц, проработавших в контакте с вредными производственными факторами от 10 до 30 лет (средний стаж 23,3 \pm 0,4 г.).

В нозологическом спектре накопленной профессиональной заболеваемости первое ранговое место занимали заболевания периферической нервной системы $(39,5 \%)$, а именно пояснично-крестцовая радикулопатия, второе - заболевания органов дыхания (19,4\%): хроническая обструктивная болезнь легких, хронический пылевой необструктивный бронхит, бронхиальная астма, третье - вибрационная болезнь (18,3\%), четвертое - нейросенсорная тугоухость (15,6 \%). При этом в последние 7 лет сформировалась стойкая тенденция роста количества лиц с впервые выявленными сочетанными ПЗ: только у 55,2 \% механизаторов сельского хозяйства было диагностировано одно ПЗ, у 39,4 \% - 2 заболевания, у 11,9 \% - 3. Однако в 76,4 \% случаев при сочетанной профпатологии в качестве ос- 


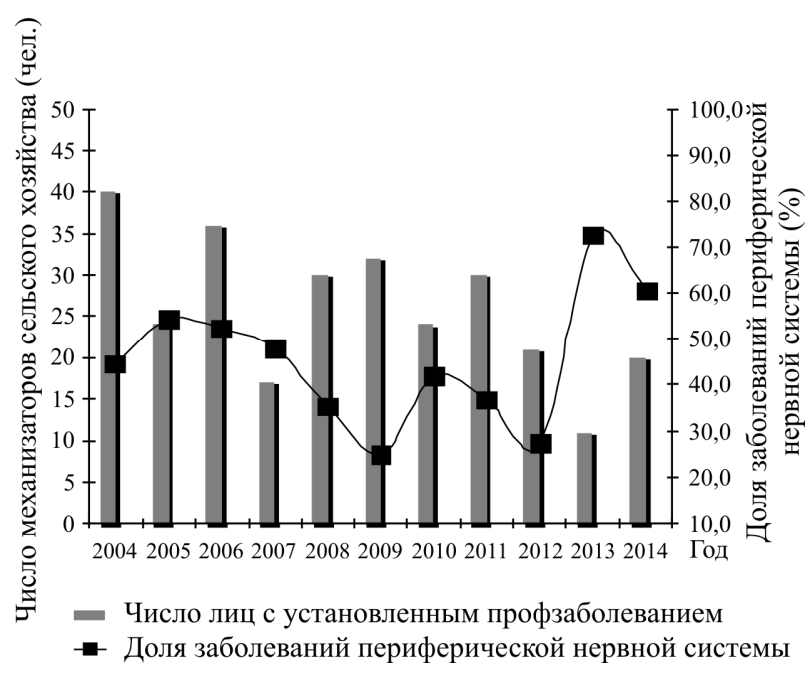

Рис. Распространенность профессиональных заболеваний периферической нервной системы

новного диагноза регистрировалась радикулопатия пояснично-крестцового уровня (рисунок).

Необходимо подчеркнуть, что факторы, формирующие вредные условия труда при работе на мобильной сельскохозяйственной технике, способны вызывать развитие заболеваний периферической нервной системы поясничнокрестцового отдела только при относительно длительном профессиональном стаже. Наши наблюдения показывают, что дебютом пояснично-крестцовой радикулопатии у этой категории работающих, как правило, являются алгические синдромы, возникающие при стаже работы в профессии не менее 10 лет. Эти данные согласуются с результатами исследований других авторов, свидетельствующих, что в ряде профессий, сходных с условиями труда на мобильной сельскохозяйственной технике по своим санитарно-гигиеническим характеристикам, профессиональная вертеброгенная патология пояснично-крестцового отдела развивается в среднем спустя 10-15 лет от начала работы в профессии [2].

С учетом категорий риска, тяжести и индекса профзаболеваний, являющихся в соответствии c P 2.2.1766-03 неотъемлемой составляющей оценки профессионального риска для здоровья, заболевания периферической нервной системы у механизаторов сельского хозяйства были отнесены к высокой категории риска с индексом профессиональных заболеваний, равным $0,5 \%$.

Таким образом, результаты проведенного исследования свидетельствуют, что, несмотря на имеющее место обновление машинотракторного парка, условия труда в профессии тракториста-машиниста сельскохозяйственного производства продолжают оставаться вредными и представляют риск развития профессиональных заболеваний периферической нервной системы, а именно рефлекторных и компрессионных синдромов пояснично-крестцового уровней, связанных с функциональным перенапряжением, что необходимо учитывать при разработке мероприятий по профилактике профессиональной патологии у этой категории работников сельского хозяйства.

Результаты проведенных исследований явились основой для разработки приоритетных гигиенических и медико-профилактических мероприятий, направленных на снижение риска нарушений здоровья механизаторов.

В связи с тем, что полностью исключить вредное воздействие факторов рабочей среды и трудового процесса на механизаторов на современном этапе невозможно, так как машинотракторный парк сельскохозяйственных организаций на 70-75 \% представлен морально устаревшей и физически изношенной техникой, особое значение приобретают гигиенические и санитарно-технические мероприятия. В первую очередь это обновление техники, строгое соблюдение сроков текущего и капитального ремонтов, гигиеническая регламентация и контроль уровней факторов рабочей среды, гигиеническая и физиологическая рационализация технологических процессов и режима труда и отдыха, дифференцированный научно обоснованный профессиональный отбор среди поступающих на работу с учетом индивидуальных особенностей, антропометрических данных и наличия противопоказаний для работы в данной профессии.

\section{Список литературы}

1. Буянов Е.С., Новикова Т.А. Априорный профессиональный риск для здоровья механизаторов сельского хозяйства // Здоровье населения и среда обитания. - 2011. - № 12. - С. 33-36.

2. Исследование эффективности габапентина (гебантина) при лечении различных видов невропатической боли / С.С. Павленко, Е.В. Танеева, И.А. Веретельников, Л.Д. Сорогина // Боль. - 2007. - № 1. - С. 37-40.

3. Михалева Т.С. Условия формирования и течения основных клинических синдромов с алгическими проявлениями при профессиональной вертеброгенной патологии пояснично-крестцового уровня // Медицина труда и промышленная экология. - 2005. - № 6. - С. 23-27. 
4. Некачалов В.В. Патология костей и суставов. - СПб.: Мотис, 2000. - 285 с.

5. Новикова Т.А. Гигиенические аспекты оценки и управления профессиональным риском для здоровья механизаторов сельского хозяйства // Здравоохранение Российской Федерации. - 2011. - № 4. - С. $72-73$.

6. Онищенко Г.Г. Состояние условий труда и профессиональной заболеваемости работников Российской Федерации // Гигиена и санитария. - 2009. - № 1. - С. 29-33.

7. Подчуфарова Е.В. Диагностика и лечение боли в пояснично-крестцовой области // Врач. - 2008. № 9. - С. 33-37.

8. Попелянский Я.Ю. Ортопедическая неврология (вертеброневрология): руководство для врачей. М.: МЕДпресс-информ, 2003. - 670 с.

9. Профессиональная патология: национальное руководство / под ред. Н.Ф. Измерова. - М.: ГЭОТАРМедиа, 2011. - 784 с.

10. Ширшов А.В., Пирадов М.А.. Поясничный остеохондроз: диагностика, клиника и лечение // Русский медицинский журнал. - 2004. - Т. 12, № 4. - С. 3-6.

11. Шурщуков Ю.Ю., Солдатова П.Ф. Исследование распространенности болезней костно-мышечной системы и соединительной ткани среди взрослого сельского населения Липецкой области // Медицина труда и промышленная экология. - 2007. - № 2. - С. 41-44.

12. Liszka-Hackzell J.J., Martin D.P. An analysis of the relationship between activity and pain in chronic and acute low back pain // J. Anesth Analg. - 2004. -Vol. 99, № 2. - P. 477-481.

\section{References}

1. Buyanov E.S., Novikova T.A. Apriornyj professional'nyj risk dlja zdorov'ja mehanizatorov sel'skogo hozjajstva [Prior occupational health risk of agricultural industry operators]. Zdorov'e naselenija i sreda obitanija, 2011, no. 12, pp. 33-36.

2. Pavlenko S.S., Taneeva E.V., Veretel'nikov I.A., Sorogina L.D. Issledovanie jeffektivnosti gabapentina (gebantina) pri lechenii razlichnyh vidov nevropaticheskoj boli [Study of the efficacy of gabapentin (gebantin) on treatment of various types of neuropathic pain]. Bol', 2007, no. 1, pp. 37-40.

3. Mihaleva T.S. Uslovija formirovanija i techenija osnovnyh klinicheskih sindromov s algicheskimi projavlenijami pri professional'noj vertebrogennoj patologii pojasnichno-krestcovogo urovnja [Conditions of formation and development of major clinical syndromes with allergic presentations at professional vertebrogenic pathology of lumbosacral level]. Medicina truda i promyshlennaja jekologija, 2005, no. 6, pp. 23-27.

4. Nekachalov V.V. Patologija kostej i sustavov [Pathology of bones and joints]. Saint-Petersburg.: Motis, 2000. 285 p.

5. Novikova T.A. Gigienicheskie aspekty ocenki i upravlenija professional'nym riskom dlja zdorov'ja mehanizatorov sel'skogo hozjajstva [Hygienic aspects of assessment and management of occupational health risks of agricultural industry operators]. Zdravoohranenie Rossijskoj Federacii, 2011, no. 4, pp. 72-73.

6. Onishhenko G.G. Sostojanie uslovij truda i professional'noj zabolevaemosti rabotnikov Rossijskoj Federacii [State ofvworking conditions and occupational morbidity of workers of the Russian Federation]. Gigiena $i$ sanitarija, 2009, no. 1, pp. 29-33.

7. Podchufarova E.V. Diagnostika i lechenie boli v pojasnichno-krestcovoj oblasti [Diagnostics and pain management in the lumbosacral region]. Vrach, 2008, no. 9, pp. 33-37.

8. Popelyanskiy Ja.Ju. Ortopedicheskaja nevrologija (vertebronevrologija). Rukovodstvo dlja vrachej [Orthopedic neurology (vertebroneurology). Guidelines for doctors]. Moscow: MEDpress-inform, 2003. 670 p.

9. Professional'naja patologija. Nacional'noe rukovodstvo [Professional pathology. National guideline]. Edit by N.F. Izmerov. Moscow: GJeOTAR-Media, 2011. 784 p.

10.Shirshov A.V., Piradov M.A.. Pojasnichnyj osteohondroz: diagnostika, klinika i lechenie [Lumbar osteochondrosis: diagnostics, clinic and treatment]. Russkij medicinskij zhurnal, 2004, vol. 12, no. 4, pp. 3-6.

11.Shurshhukov Ju.Ju., Soldatova P.F. Issledovanie rasprostranennosti boleznej kostno-myshechnoj sistemy i soedinitel'noj tkani sredi vzroslogo sel'skogo naselenija Lipeckoj oblasti [Prevalence study of diseases of musculoskeletal system and connective tissue in the adult rural population of Lipetsk region]. Medicina truda $i$ promyshlennaja jekologija, 2007, № 2, pp. 41-44.

12.Liszka-Hackzell J.J., Martin D.P. An analysis of the relationship between activity and pain in chronic and acute low back pain. J. Anesth Analg, 2004, vol. 99, no. 2, pp. 477-481. 


\section{PROFESSIONAL RISK OF DEVELOPING DISEASES OF THE PERIPHERAL NERVOUS SYSTEM IN TRACTOR DRIVERS - MACHINE OPERATORS OF AGRICULTURAL PRODUCTION}

\section{G.A. Bezrukova, T.A. Novikova, M.L. Shalashova, S.S. Raikin}

FBSI "Saratov Scientific Research Institute of Agricultural Hygiene"

of the Federal Service for Consumer Rights Protection and Human Well-Being Surveillance, Russian Federation, Saratov, 1A Zarechnaya St., 410022

Based on the results of the hygienic assessment of working conditions in the domestic agricultural machinery of old and new models when performing the main types of seasonal agricultural work during the annual production cycle and analysis of accumulated occupational diseases' nosology structure in agricultural workers of the Saratov region over the period from 2004 to 2014, the estimation of professional risk diseases of the peripheral nervous system in tractor drivers machine operators of agricultural production is given. Professional risk assessment carried out under the procedure set forth in P2.2.1766-03 has shown that the category of a priori risk to their health during an annual production cycle ranged from high to very high (unbearable). It was revealed that the most important factors shaping the harmful working conditions when working on agricultural machinery that can act as a trigger in the formation of vertebral diseases of the peripheral nervous system, are general and local vibration, adverse micro-climatic conditions, long uncomfortable static working posture and physical stress. The risk of diseases in the peripheral uneven system in machine operators of agriculture was attributed to the high risk category with an index of professional diseases (IPD) equal to $05 \%$.

Key words: tractor drivers - machine operators of agricultural production, harmful factors of production environment and labor process, professional diseases of the peripheral nervous system.

(C) Bezrukova G.A., Novikova T.A., Shalashova M.L., Raikin S.S., 2015

Bezrukova Galina Aleksandrovna - Doctor of Medicine, Associate Professor, Chief Researcher of the Institute (e-mail: bezrukovagala@yandex.ru; tel. +7 (845-2) 92-78-90, 92-34-94).

Novikova Tamara Anatolievna - Candidate of Biological Sciences, Associate Professor, Head of the Laboratory of Occupational Hygiene in Agriculture and Processing Industry (e-mail: niisgsar@rol.ru; tel. +7 (8452) 922768).

Shalashova Maria Leontievna - Doctor of the Clinic of occupational diseases in FBSI Scientific Research Institute of Agricultural Hygiene, Rospotrebnadzor (e-mail: niisgsar@rol.ru; tel. +7 (8452) 922768).

Raikin Sergey Sergeevich - Junior Researcher, Laboratory of Occupational Hygiene in Agriculture and Processing Industry (e-mail: niisgsar@rol.ru; tel. +7 (8452) 922768). 
УДК 612.766.1: 63.321 .933

\title{
ОЦЕНКА ФУНКЦИОНАЛЬНОГО СОСТОЯНИЯ И АДАПТАЦИОННЫХ РЕЗЕРВОВ МЕХАНИЗАТОРОВ СЕЛЬСКОГО ХОЗЯЙСТВА С РАЗЛИЧНЫМ СТАЖЕМ РАБОТЫ В ПРОФЕССИИ
}

\author{
С.С. Райкин, Т.А. Новикова \\ ФБУН «Саратовский научно-исследовательский институт сельской гигиены» Федеральной службы \\ по надзору защиты прав и благополучия человека, Россия, 410022, г. Саратов, ул. Заречная, 1А
}

Представлены результаты оценки показателей гемодинамики (артериальное давление, частота сердечных сокращений, минутный объем крови, общее периферическое сопротивление сосудов) и адаптации (адаптационный потенциал системы кровообращения, индекс физического состояния, индекс массы тела) к производственным нагрузкам механизаторов сельского хозяйства с различным стажем работы в профессии. Установлено, что $27 \%$ обследованных находились в состоянии неудовлетворительной адаптации и 18,8 \% в состоянии срыва адаптационных возможностей, когда функииональные резервы организма резко снижены, что свидетельствует о том, что работа во вредных условиях труда приводит к достоверному ухудшению функиионального состояния и истощению адаптационных резервов организма. Выявлено, что профессиональный стаж работы 10 лет и более является фактором риска здоровью механизаторов сельского хозяйства, обусловливая нарушения функиионального состояния и истощение адаптационных резервов организма, что подтверждается статистически значимыми корреляционными связями между показателями функиионального состояния и стажем работы в профессии.

Ключевые слова: механизаторы сельского хозяйства, условия труда, стаж работы в профессии, функииональное состояние, адаптационный потенциил организма.

Увеличение объемов производства и переработки основных видов отечественной продукции растениеводства, в том числе увеличение производства зерна в соответствии с «Программой развития сельского хозяйства и регулирования рынков сельскохозяйственной продукции, сырья и продовольствия на 2013-2020 годы»одна из основных стратегических задач продовольственной безопасности России.

Основной профессиональной группой зернового растениеводства являются трактористымашинисты сельского хозяйства (механизаторы сельского хозяйства), занятые на работах по предпосевной подготовке почвы, посеве зерновых культур и уборке урожая, на различной по назначению и видам сельскохозяйственной технике - тракторах в агрегате с различными прицепными и навесными орудиями, самоходных сельскохозяйственных машинах, в том числе зерноуборочных комбайнах. Полевые работы проводятся в непрерывном режиме в определенные, сжатые сроки, поскольку жестко привязаны к климатическим коридорам и периодам вегетации растений. В связи с этим важна надежность работы системы «оператор-машина», «слабым звеном» которой может выступать человек.

Трудовая деятельность механизаторов сельского хозяйств протекает в условиях воздействия целого комплекса вредных профессионально обусловленных факторов условий труда: повышенные уровни шума и вибрации, микроклиматический дискомфорт, запыленность и загрязнённость воздуха рабочей зоны вредными веществами, чрезмерные физические и эмоциональные нагрузки. Следует отметить, что работа на изношенной, выработавшей свой ресурс технике, численность которой в отдельных сельскохозяйственных организациях достигает $70 \%$ и более, может способствовать усилению воздействия вредных факторов на здоровье механизаторов. Ранее нами было установлено, что уровни факторов условий труда зависели от вида выполняемых работ, марки техники и сроков ее эксплуатации и соответст-

(C) Райкин С.С., Новикова Т.А., 2015

Новикова Тамара Анатольевна - кандидат биологических наук, доцент, руководитель лаборатории гигиены труда в сельском хозяйстве и перерабатывающей промышленности (e-mail: novikovata-saratov@yandex.ru; тел. 8 (8452) 34-71-84).

Райкин Сергей Сергеевич - младший научный сотрудник лаборатории гигиены труда в сельском хозяйстве и перерабатывающей промышленности (e-mail: Rser3001@yandex.ru; тел. 89172013553). 
вовали по степени отклонения от гигиенических нормативов вредным условиям труда 1-4-й степени (классы 3.1-3.4) [4]. Вредные условия труда могут служить факторами риска развития профессиональных и общесоматических заболеваний, являющихся причиной временной, а в ряде случаев стойкой потери трудоспособности и инвалидизации механизаторов $[5,6]$.

В связи с вышеизложенным проблема сохранения здоровья и трудового долголетия одной из основных профессиональных групп сельскохозяйственных рабочих ставит задачу обеспечения безопасности их труда. Согласно накопленным в медицине труда знаниям, решение данной задачи возможно не только путем обеспечения соответствия уровней факторов производственной среды санитарным нормам, но и посредством мер, направленных на предупреждение перенапряжения организма и ограничение физиологической стоимости трудового процесса $[2,5]$.

Особое значение приобретает изучение функционального состояния, выявление степени напряжения и перенапряжения регуляторных механизмов, снижения адаптационного потенциала организма механизаторов в процессе трудовой деятельности, позволяющих определить индивидуальное здоровье работающих в профессии тракториста-машиниста сельскохозяйственного производства и своевременно принять профилактические меры.

Целью исследования явилась оценка функционального состояния и степени адаптированности к производственным нагрузкам механизаторов сельского хозяйства с различным стажем работы в профессии.

Материалы и методы. Исследования функционального состояния организма механизаторов сельского хозяйства проводились в условиях трудовой деятельности до начала рабочей смены в хозяйствах Саратовской области, специализирующихся на производстве зерна. Было обследовано 85 механизаторов в возрасте от 30 до 59 лет (средний возраст $42,4 \pm 11,1$ г.) со стажем работы в профессии от 3 до 35 лет (в среднем 19,6 $\pm 11,6$ г.). В соответствии с требованиями биомедицинской этики на участие в исследовании было получено информированное согласие всех обследованных.

Изучались антропометрические показатели (рост, масса тела, индекс массы тела). Для оценки уровня физического здоровья применялся индекс физического состояния (ИФС) Пироговой с соавт. (1986). Расчет ИФС производился по формуле
700-(3ЧСС)-(0,8333САД)-(1,6667ДАД)-(2,7В)+(0,28М) ИФС $=\frac{}{350-(2,6 \mathrm{~B})+(0,21 \mathrm{P})}$

где ЧСС - частота сердечных сокращений, уд. в мин; САД - систолическое артериальное давление, мм рт.ст.; ДАД - диастолическое артериальное давление, мм рт.ст.; В - возраст, лет; М - масса тела, кг; Р - рост, см. Физическое состояние обследованных оценивалось по следующим числовым градациям: низкий уровень - менее 0,375; уровень ниже среднего - от 0,376 до 0,525 ; средний уровень - от 0,526 до 0,675 ; выше среднего - от 0,676 до 0,825; высокий уровень физического состояния - 0,826 и более [3].

Функциональное состояние организма осуществлялось по данным показателей сердечнососудистой системы, играющей первостепенную роль в адаптационно-приспособительной деятельности организма в целом. Измерялись артериальное давление крови систолическое (САД) и диастолическое (ДАД), частота сердечных сокращений (ЧСС), рассчитывались пульсовое давление (ПД), среднее динамическое давление (СДД), минутный объем крови (МОК) и общее периферическое сопротивление сосудов (ОПСС).

Для оценки адаптивных возможностей функционирования организма в целом был использован адаптационный потенциал (АП) системы кровообращения по Р.М. Баевскому, А.П. Берсеневой [1].

Расчет уровня адаптационного потенциала производился по формуле

$$
\begin{gathered}
\mathrm{A}=0,011 \text { }=0+0,014 \mathrm{CАД}+0,008 Д А Д+ \\
+0,014 \mathrm{~B}+0,09 \mathrm{M}-(0,009 \mathrm{P}+0,27),
\end{gathered}
$$

где ЧСС - частота сердечных сокращений в 1 мин; САД и ДАД - артериальное давление систолическое и диастолическое, мм рт. ст.; В возраст, лет; М - масса тела, кг; Р - рост, см.

Согласно предложенной авторами шкале, уровень функционирования организма расценивался следующим образом: при значении АП до 2,59 балла - достаточные функциональные возможности, удовлетворительная адаптация; от 2,60 до 3,09 балла - состояние функционального напряжения механизмов адаптации; 3,10-3,49 балла - адаптационные возможности снижены, неудовлетворительная адаптация; 3,50 балла и выше - резко сниженные функциональные возможности, срыв механизмов адаптации [1]. 
Статистическая обработка результатов исследования проведена с помощью электронных таблиц Microsoft и программы Statistica 10. Были рассчитаны средняя арифметическая $(M)$ и стандартное отклонение $(S D)$, медиана $(M e)$, 25-й и 75-й процентили. Достоверность различий уровней показателей в подгруппах определяли по $U$-критерию Манна-Уитни. Была рассчитана ранговая корреляция Спирмена $\left(r_{s}\right)$. Различия считали статистически значимыми при уровне $p<0,05$.

Результаты и их обсуждение. Анализ полученных результатов исследований показал, что физическое и функциональное состояние механизаторов на момент обследования было неудовлетворительным. У $31 \%$ из них выявлен низкий уровень индекса физического состояния и у $25 \%$ - ниже среднего. Избыточная масса тела зарегистрирована у $33 \%$ обследованных, у 15 \% установлено ожирение первой степени. Известно, что избыточная масса тела является одним из факторов риска развития артериальной гипертензии. Среднегрупповые значения систолического артериального давления и пульсового давления у находившихся под наблюдением механизаторов составили $148,0 \pm 20,3$ и $63,0 \pm 17,2$ мм рт. ст. соответственно (при диастолическом артериальном давлении $85,0 \pm 11,9$ мм рт. ст.), что превышало границы физиологических норм и было расценено нами как свидетельство нарушения компенсаторно-приспособительных возможностей сердечно-сосудистой системы. По уровню среднегруппового значения среднего динамического давления, которое составило $106,0 \pm 12,9$ (медиана и квартили: 105,3, 97,3 и 113,3 мм рт. ст. соответственно), также можно говорить о рассогласовании механизмов регуляции кровообращения. Корреляционный анализ позволил подтвердить зависимость повышенного артериального давления от избыточной массы тела - была установлена положительная корреляция индекса массы тела с систолическим, диастолическим и средним динамическим артериальным давлением $\left(r_{s}=0,35\right.$; $r_{s}=0,29$ и $r_{s}=0,36$ соответственно, $\left.p<0,05\right)$.

Исходя из того что степень напряжения регуляторных систем является интегральным ответом организма на весь комплекс воздействующих на него факторов, особое внимание нами уделялось оценке индекса функциональных изменений по Р.М. Баевскому и А.П. Берсеневой (1997). Среднегрупповой уровень ИФИ у обследованных механизаторов составил $3,04 \pm 0,50$ балла, что со- ответствовало состоянию функционального напряжения. При этом 27,0 \% обследованных находились в состоянии неудовлетворительной адаптации и $18,8 \%$ в состоянии срыва адаптационных возможностей, когда функциональные резервы организма резко снижены, что, согласно теории адаптации, свидетельствовало о включении дополнительных внутренних резервов организма для обеспечения продолжительного функционирования в данных условиях. Механизаторы, находящиеся в состоянии неудовлетворительной адаптации и, в особенности, в состоянии срыва адаптационных возможностей, представляют группу повышенного риска для развития патологических состояний и развития острых заболеваний или обострения хронических.

Для выявления зависимости адаптационных резервов организма механизаторов от профессионального стажа работы среди обследованных были выделены четыре подгруппы с различным стажем работы в профессии: подгруппа 1 - до 10 лет, подгруппа 2 - от 10 до 19 лет, подгруппа 3 - от 20 до 29 лет, подгруппа 4 - 30 лет и более.

Было установлено, что индекс массы тела с увеличением стажа работы возрастал, что, видимо, сопряжено с увеличением возраста, однако различия значений индекса массы тела были статистически не достоверны (таблица).

Наибольшая доля лиц $(62,5 \%)$ с соответствующим норме ИМТ входила в подгруппу 1 со стажем работы до 10 лет. В подгруппе 2 доля лиц с нормальным индексом массы тела была меньше и составляла $57,7 \%$, кроме того у $11,5 \%$ из них установленный уровень ИМТ соответствовал ожирению I степени. В подгруппах 3 и 4 ожирение I степени было отмечено у 24 и у $22 \%$ соответственно, у 32 и $33 \%$ - масса тела была избыточной.

При сравнении значений показателей гемодинамики у механизаторов с различным профессиональным стажем работы более целесообразные изменения выявлены у лиц, проработавших в профессии меньшее количество лет. Уровни артериального давления крови, как систолического, так и диастолического, с увеличением стажа работы в профессии повышались, и в 4-й стажевой подгруппе были наибольшие, достоверно различаясь $(p<0,05-0,01)$ с уровнями в подгруппе 1 . Установлено, что в подгруппах 1 и 2 повышенное систолическое артериальное давление имели 50 \% обследованных, при этом в подгруппе 1 
Показатели функционального состояния и адаптационных резервов организма механизаторов с различным стажем работы в профессии

\begin{tabular}{|c|c|c|c|c|c|c|c|c|}
\hline \multirow{3}{*}{ Показатель } & \multicolumn{8}{|c|}{ Стажевые подгруппы } \\
\hline & \multicolumn{2}{|c|}{$\begin{array}{c}\text { подгруппа } 1, \\
n=16\end{array}$} & \multicolumn{2}{|c|}{$\begin{array}{c}\text { подгруппа } 2, \\
n=26 \\
\end{array}$} & \multicolumn{2}{|c|}{$\begin{array}{c}\text { подгруппа } 3, \\
n=25\end{array}$} & \multicolumn{2}{|c|}{$\begin{array}{c}\text { подгруппа } 4, \\
n=18\end{array}$} \\
\hline & $M$ & $S D$ & $M$ & $S D$ & $M$ & $S D$ & $M$ & $S D$ \\
\hline Возраст, лет & 29,1 & 5,8 & 45,4 & 6,2 & 38,0 & 8,1 & 56,4 & 3,4 \\
\hline Профессиональный стаж, лет & 4,2 & 2,4 & 13,6 & 2,6 & 23,1 & 3,0 & 37,2 & 4,3 \\
\hline Масса тела, кг & 71,6 & 11,8 & 73,7 & 13,6 & 77,8 & 15,3 & 78,0 & 12,1 \\
\hline ИМТ, кг $/ \mathrm{M}^{2}$ & 23,6 & 3,0 & 24,9 & 4,2 & 26,3 & 4,9 & 26,2 & 3,6 \\
\hline САД, мм рт.ст. & 140,8 & 13,5 & $148,4^{* *}$ & 25,7 & $145,0 * *$ & 17,4 & $158,2^{*}$ & 17,2 \\
\hline ДАД, мм рт. ст. & 77,7 & 13,9 & 84,3 & 11,5 & $85,2^{* *}$ & 9,8 & $92,2^{*}$ & 9,8 \\
\hline ЧСС, уд. / мин & 78,6 & 11,1 & 74,3 & 10,0 & 76,8 & 9,7 & 76,5 & 14,3 \\
\hline ПД, мм рт. ст. & 63,1 & 17,0 & 64,0 & 21,1 & 59,8 & 14,4 & 65,9 & 15,6 \\
\hline СДД, мм рт. ст. & 98,7 & 11,2 & $105,7^{* *}$ & 14,5 & $105,1 * *$ & 10,9 & $114,2^{*}$ & 10,4 \\
\hline МОК, мл /мин & 4922,0 & 1304,6 & $4020,9^{*} ; * *$ & 994,8 & $3626,2^{*} ; * *$ & 996,7 & $2966,0^{*}$ & 733,2 \\
\hline ОПСС, дин & 1750,9 & 661,9 & $2259,3 * ; * *$ & 755,4 & $2512,8^{*} ; * *$ & 852,4 & $3280,4^{*}$ & 999,4 \\
\hline АП, баллы & 2.675 & 0,367 & $2,947 * *$ & 0,563 & $3,073 * ; * *$ & 0,403 & $3,462 *$ & 0,334 \\
\hline ИФС & 0,507 & 0,171 & $0,446^{* *}$ & 0,201 & $0,392 * ; * *$ & 0,136 & $0,227^{*}$ & 0,214 \\
\hline
\end{tabular}

П р и м е ч а н и е: * различия достоверны по сравнению с подгруппой 1 ; * - различия достоверны по сравнению с подгруппой 4.

преобладало САД в диапазоне 140-159 (у 33\%), а в подгруппе 2 в пределах 160-179 (у 23\%). В подгруппе 3 повышенное систолическое артериальное давление отмечено у $40 \%$, а в подгруппе 4 - у $89 \%$. Следует отметить, что у механизаторов со стажем работы более 30 лет систолическое давление в диапазонах 140-159 и 160-179 мм рт. ст. составляло почти по $40 \%$, и у $11 \%$ САД было выше 180 мм рт. ст. В подгруппе 4 у 45 \% отмечено повышенное диастолическое артериальное давление. Уровни минутного объема крови и общего периферического сопротивления сосудов достоверно $(p<0,03)$ отличались по сравнению с таковыми в остальных подгруппах. Выявленные изменения показателей гемодинамики у обследованных механизаторов свидетельствуют о нарастании рассогласования механизмов регуляции кровообращения с увеличением стажа работы, а соответственно и возраста, что может расцениваться как проявление предпатологических состояний.

Оценка ИФС у лиц с различным стажем работы в профессии показала, что в стажевых подгруппах 1 и 2 низкий уровень физического состояния имели 25 и $26 \%$ обследованных соответственно. С увеличением возраста и стажа отмечено резкое нарастание числа лиц с низким уровнем индекса физического состояния: так, в подгруппах 3 и 4 их доля составляла 48 и $72 \%$ соответственно.

Во всех изучаемых подгруппах зафиксированы повышенные значения адаптационного потенциала, свидетельствующие о нарушении адаптации. После 10 лет работы в профессии отмечалось резкое, более чем в 3,5 раза по сравне- нию с подгруппой 1, возрастание доли обследованных с неудовлетворительной адаптацией (до 23,08 \%), у механизаторов уровни АП соответствовали состоянию срыва адаптации. С увеличением стажа работы отмечается тенденция к нарастанию числа срывов адаптационных возможностей организма: так, в подгруппе 3 доля таких лиц составила $16 \%$, а в группе $4-50 \%$. Уровни адаптационного потенциала в подгруппах 3 и 4 достоверно выше по сравнению с подгруппой 1 ( $p=0,003594$ и 0,000001 соответственно).

Выводы. Установлено, что у обследованных механизаторов сельского хозяйства, трудовая деятельность которых связана с сочетанным воздействием комплекса вредных факторов условий труда, наблюдалось ухудшение функционального состояния организма и снижение адаптационного потенциала, что усугублялось с увеличением стажа работы в профессии.

На основании полученных данных можно заключить, что профессиональный стаж работы 10 лет и более является фактором риска здоровью механизаторов сельского хозяйства, обусловливая нарушения функционального состояния и истощение адаптационных резервов организма, что подтверждается статистически значимыми корреляционными связями между показателями функционального состояния и стажем работы в профессии.

Результаты исследований свидетельствуют об актуальности разработки и реализации комплекса профилактических мероприятий, направленных на восстановление функциональных резервов организма механизаторов сельского хозяйства в процессе трудовой деятельности. 


\section{Список литературы}

1. Баевский Р.М., Берсенева А.П. Оценка адаптационных возможностей организма и риск развития заболеваний. - М.: Медицина, 1997. - 320 с.

2. Мелентьев А.В. Подходы к профилактике кардиоваскулярного риска у рабочих промышленных предприятий // Здоровье населения и среда обитания. - 2012. - № 9 (234). - С. 12-13.

3. Пирогова Е.А., Иващенко Л.Я., Страпко Н.П. Влияние физических упражнений на работоспособность и здоровье человека. — Киев: Здоровье, 1986. - С. 4-143.

4. Профессиональный риск для здоровья работников сельского хозяйства, гигиенические аспекты его оценки и управления (обзор литературы) / Т.А. Новикова, В.Ф. Спирин, Н.А. Михайлова, В.М. Таранова // Медицина труда и промышленная экология. - 2012. - № 5. - С. 22-28.

5. Спирин В.Ф., Новикова Т.А., Герштейн Е.Г. Гигиенические проблемы управления профессиональными рисками у работников сельского хозяйства // Здравоохранение Российской Федерации. - 2008.№ 1. - С. 19-20.

6. Условия труда как факторы профессионального риска функциональных нарушений у механизаторов сельского хозяйства / Т.А. Новикова, С.С. Райкин, В.С. Буянов, В.Ф. Спирин, Р.Б. Рахимов // Анализ риска здоровью. - 2014. - № 2. - С. 48-53.

\section{References}

1. Baevskiy R.M., Berseneva A.P. Ocenka adaptacionnyh vozmozhnostej organizma i risk razvitija zabolevanij [Assessment of adaptation capabilities of organism and risk of diseases]. Moscow: Medicina, 1997. 320 p.

2. Melentyev A.V. Podhody k profilaktike kardiovaskuljarnogo riska u rabochih promyshlennyh predprijatij [Approaches to prevention of cardiovascular risk in workers of industrial undertakings]. Zdorov'e naselenija $i$ sreda obitanija, 2012, no. 9 (234), pp. 12-13.

3. Pirogova E.A., Ivashhenko L.Ja., Strapko N.P. Vlijanie fizicheskih uprazhnenij na rabotosposobnost' i zdorov'e cheloveka [Effect of physical exercises on working capacity and human health]. Kiev: Zdorov'e, 1986, pp. 4-143.

4. Novikova T.A., Spirin V.F., Mihaylova N.A., Taranova V.M. Professional'nyj risk dlja zdorov'ja rabotnikov sel'skogo hozjajstva, gigienicheskie aspekty ego ocenki i upravlenija (obzor literatury) [Professional health risk of workers in agriculture, sanitary aspects of its assessment and management (review of literature) ]. Medicina truda i promyshlennaja jekologija, 2012, no. 5. pp. 22-28.

5. Spirin V.F., Novikova T.A., Gershtejn E.G. Gigienicheskie problemy upravlenija professional'nymi riskami u rabotnikov sel'skogo hozjajstva [Hygienic problems of occupational risks management in agricultural workers]. Zdravoohranenie Rossijskoj Federacii, 2008, no. 1, pp. 19-20.

6. Novikova T.A., Raykin S.S., Buyanov V.S., Spirin V.F., Rahimov R.B. Uslovija truda kak faktory professional'nogo riska funkcional'nyh narushenij u mehanizatorov sel'skogo hozjajstva [Working conditions as factors of occupational risk of functional disorders in agricultural operators]. Analiz riska zdorov'ju, 2014, no. 2, pp. 48-53. 


\section{ASSESSMENT OF FUNCTIONAL STATE AND ADAPTATION RESERVES OF MACHINE OPERATORS IN AGRICULTURE WITH DIFFERENT WORK EXPERIENCE IN THE PROFESSION}

\section{S.S. Raikin, T.A. Novikova}

FBSI "Saratov Scientific Research Institute of Agricultural Hygiene" of the Federal Service for Consumer Rights Protection and Human Well-Being Surveillance, Russian Federation, Saratov, 1A Zarechnaya St., 410022

The results of hemodynamic parameters' evaluation (blood pressure, heart rate, minute volume of blood, total peripheral vascular resistance) and adaptation (adaptive capacity of the circulatory system, the index of physical condition, body mass index) to job strains in machine operators of agriculture with a different experience in the profession are presented. It was found that $27 \%$ of the patients - machine operators were in a state of unsatisfactory adaptation and $18.8 \%$ in the state of failure of adaptation options when functional body reserves were sharply reduced, indicating that the work in hazardous conditions resulted in a significant deterioration of the functional state of exhaustion and adaptation reserves. It was found that the professional experience of 10 years or more is a risk factor for the health of machine workers in agriculture, causing the violation of functional state and exhaustion of adaptive reserves of an organism, as evidenced by a statistically significant correlation between the indicators of functional status and work experience in the profession.

Key words: agricultural machine operators, working conditions, work experience in the profession, functional state, organism adaptive capacity.

(C) Raikin S.S., Novikova T.A., 2015

Novikova Tamara Anatolievna - Candidate of Biological Sciences, Associate Professor, Head of the Laboratory of Occupational Hygiene in Agriculture and Processing Industry (e-mail: novikovata-saratov@yandex.ru; tel. 8 (845-2) 34-71-84).

Raikin Sergey Sergeevich - Junior Researcher, Laboratory of Occupational Hygiene in Agriculture and Processing Industry (e-mail: Rser3001@yandex.ru; tel. 89172013553). 


\title{
МЕДИКО-БИОЛОГИЧЕСКИЕ АСПЕКТЫ ОЦЕНКИ ВОЗДЕЙСТВИЯ ФАКТОРОВ РИСКА
}

УДК 613.64: $616.717-057$

\section{СИСТЕМА МЕДИАТОРОВ ИММУННОЙ РЕГУЛЯЦИИ КАК МАРКЕРОВ ИММУНОЛОГИЧЕСКИХ НАРУШЕНИЙ У ШКОЛЬНИКОВ В УСЛОВИЯХ ПОВЫШЕННОГО ПОСТУПЛЕНИЯ СТРОНЦИЯ С ПИТЬЕВОЙ ВОДОЙ}

\author{
О.В. Долгих ${ }^{1,2}$, А.В. Кривцов ${ }^{1}$, К.Г. Старкова ${ }^{1}$, В.А. Лучникова ${ }^{1}$, \\ О.А. Бубнова ${ }^{1,2}$, Д.Г. Дианова ${ }^{1}$, Н.В. Безрученко ${ }^{1,2}$, Н.А. Вдовина ${ }^{1}$ \\ ${ }^{1}$ ФБУН «Федеральный научный центр медико-профилактических технологий управления рисками \\ здоровью населения», Россия, 614045, г. Пермь, ул. Монастырская, 82 \\ ${ }^{2}$ ФГБОУ ВПО «Пермский государственный национальный исследовательский университет», \\ Россия, 614990, г. Пермь, ул. Букирева, 15
}

Проведена оценка иммунологических маркеров у школьников, экспонированных стронцием. Показано, что в условиях повыменного поступления строниия с питьевой водой индикация спонтанного и индуцированного уровня медиаторов in vitro позволяет выявить ранние функииональные нарушения иммунной системы. Установлено, что маркеры специфической гиперчувствительности и медиаторы межклеточной иммунной регуляии: $\operatorname{Ig} G$ специфические к стронцию, ичитокины IL-6, IL-10, IL-12, IL-17, $\alpha-T N F, G M-C S F$, спонтанные и специфически стимулированные, RANKL, OPG - могут быть предложены для проведения идентификаиии риска нарушения здоровья в качестве ранних маркеров изменений иммунорегуляции у школьников, проживающих в зонах стронциевых геохимических провинций.

Ключевые слова: стронций, цитокины, маркеры.

Многочисленные исследования убедительно свидетельствуют о взаимосвязи между гигиеническими факторами и состоянием иммунного статуса населения $[2,3,16]$. Изменение состояния иммунной системы является одним из показателей адаптации организма практически здоровых людей к условиям загрязнения окружающей среды химическими соединениями, в том числе металлами. Стабильный стронций входит в перечень химических веществ, обладающих иммунотропной и мутагенной активностью (токсикологические профайлы Агентства по регистрации токсичных веществ и заболеваний США (ATSDR), 2004, 2008).

(ㄷ Долгих О.В., Кривцов А.В., Старкова К.Г., Лучникова В.А., Бубнова О.А., Дианова Д.Г., Безрученко Н.В., Вдовина Н.А., 2015

Долгих Олег Владимирович - доктор медицинских наук, профессор, заведующий отделом иммунобиологических методов диагностики, профессор кафедры экологии человека и безопасности жизнедеятельности (е-таil: oleg@fcrisk.ru; тел. (342) 236-39-30).

Кривцов Александр Владимирович - кандидат медицинских наук, заведующий лабораторией иммуногенетики (e-mail: krivtsov@fcrisk.ru; тел. (342) 236-39-30).

Старкова Ксения Геннадьевна - кандидат медицинских наук, заведующий лабораторией иммунологии и аллергологии (e-mail: oleg@fcrisk.ru; тел. (342) 236-39-30).

Бубнова Ольга Алексеевна - младший научный сотрудник отдела иммунобиологических методов диагностики (e-mail: oleg@fcrisk.ru; тел. (342) 236-39-30).

Дианова Дина Гумеровна - кандидат медицинских наук, старший научный сотрудник лаборатории клеточных методов диагностики (e-mail: dianovadina@rambler.ru; тел. (342) 236-39-30).

Лучникова Виктория Александровна - младший научный сотрудник отдела иммунобиологических методов диагностики (e-mail: oleg@fcrisk.ru; тел. (342) 236-39-30).

Вдовина Надежда Алексеевна - младший научный сотрудник отдела иммунобиологических методов диагностики (e-mail: oleg@fcrisk.ru; тел. (342) 236-39-30).

Безрученко Надежда Владимировна - иммунолог отдела иммунобиологических методов диагностики (e-mail: oleg@fcrisk.ru; тел. (342) 236-39-30). 
Ионы стронция близки к ионам кальция и могут замещать последние в организме, что и является основным типом действия соединений этого элемента $[1,11,12]$. Стронций биологически конкурирует с кальцием. Показано, что ионы стронция, имея иной диаметр, нежели ионы кальция, способны блокировать ионные каналы для последнего, что может определить ингибирующее влияние стронция на иммунную реакцию, отмеченное для естественных киллеров, а также воздействие на другие клетки организма, прежде всего костную систему $[7,9]$. Распознавание Т- и В-лимфоцитами небольших молекул, каковыми являются металлы, объясняют гаптенной гипотезой, согласно которой гаптены становятся полными антигенами, ковалентно связываясь с большими протеинами или пептидами. Реакции адаптации проявляются на уровне различных и в первую очередь регуляторных систем, которые в последнее время рассматриваются в качестве функционально единых систем, определяющих поддержание гомеостаза $[2,3]$. Одними из основных звеньев иммунитета, осуществляющих иммунный ответ на средовые, в том числе техногенные химические факторы, являются регуляторные и эффекторные системы адаптивной ветви иммунитета. Поэтому для углубленного изучения состояния иммунного ответа на токсиканты в качестве индикаторных диагностических критериев сенсибилизации используют показатели специфического иммунитета - продуцируемые Т- и В-лимфоцитами цитокины и специфические антитела, а также различные гуморальные медиаторы $[10,13,15]$. $\mathrm{B}$ ходе развития иммунных реакций происходит высвобождение медиаторов - цитокинов, эндогенных регуляторов и эффекторов иммунной системы $[6,14]$. Цитокины являются сигнальными секретируемыми протеинами, которые участвуют в межклеточном и межсистемном взаимодействии, клеточном росте, дифференциации и активации; регулируют цитотоксические (противовирусные и противоопухолевые), гуморальные, клеточно-опосредованные (Th1 или Th17) или аллергические (Th2) иммунные реакции, результат которых определяется балансом продуцируемых цитокинов с проили противовоспалительными свойствами, также играют роль в процессах регуляции костного метаболизма $[4,5,8]$. Индикация спонтанного и индуцированного уровня медиаторов in vitro позволяет выявить функциональные адаптивные резервы иммунной системы в ус- ловиях экспозиции средовых антигенов, в качестве которых выступают металлы [2].

Цель работы - определить маркерные показатели иммунологических нарушений у школьников в условиях повышенного поступления стронция с питьевой водой.

Материалы и методы. При углубленном изучении состояния здоровья школьников Пермского края выполнено генетическое и иммунологическое диагностическое обследование 113 детей в возрасте от 7 до 9 лет, постоянно проживающих в эндемичной зоне, характеризующейся повышенным содержанием стронция в подземных водах (1,2 ПДК). Группу контроля составили 57 детей, проживающих на территории, характеризующейся нормативным уровнем качества воды по содержанию стронция. Группа наблюдения и контрольная группа были сопоставимы по этническому, гендерному и возрастному составу, соматической заболеваемости и социальному статусу. Выборка обследуемых была достаточна для достоверного определения межгрупповых отличий.

Исследование биосред на содержание металлов (мг/дм $\left.{ }^{3}\right)$ выполнено методом масс-спектрометрии с индуктивно связанной плазмой.

Содержание $\mathrm{IgG}$ специфических к стронцию определяли методом аллергосорбентного тестирования с ферментной меткой. На нитроцеллюлозной подложке производили конъюгацию тестируемого химического вещества с белком, в качестве контроля использовали 0,5\% раствор хлорида натрия. В дальнейшем производили инкубацию исследуемой сыворотки с антигенными комплексами, сорбированными на нитроцеллюлозной подложке, и связывание Fab-фрагментов специфических антител человека. На втором этапе иммуноферментного анализа для образования классического «сэндвича» в опытный и контрольный образец вносили конъюгированные с пероксидазой хрена моноклональные антитела к Fc-фрагменту IgG человека с последующим конкурентным связыванием специфических антител к химическому веществу со специфическими участками вариабельных доменов Fab-фрагментов моноклональных антител. После промывки лунок фосфатным буфером и проявления окраски посредством добавления хромогенного субстрата останавливали реакцию стоп-реагентом и производили удаление отработанных подложек, осуществляли фотометрическое измерение и регистрацию оптической плотности в опытном и контрольном образцах. Сопоставляли их с оп- 
тической плотностью стандартных образцов с известной концентрацией иммуноглобулина G к белку куриного яйца. Для получения таких стандартных образцов параллельно изготовляли калибровочные диски, на которые конъюгировались образцы с известным содержанием человеческих антител IgG к белку куриного яйца. Использовали стандартные образцы $\mathrm{IgG}$, конъюгат, хромогенный субстрат и стоп-реагент из набора реагентов для определения общего $\operatorname{IgG}{ }^{*}$, специфического $\operatorname{IgG}^{* *}$.

Анализ маркеров клеточной регуляции IL-6, IL-10, IL-17, системы $\alpha$-TNF, GM-CSF, VEGF в сыворотке, а также оценка секреции данных цитокинов путем активации мононуклеарных клеток цельной крови ex vivo стронцием исследовали методом ИФА с использованием тест-систем для определения цитокинов и «ЦИТОКИН-СТИМУЛ-БЕСТ» фирмы «Вектор-Бест» (г. Новосибирск) на анализаторе «Elx808IU». Действие комплекса митогенов и стронция (стронций 0,01 мг/мл) на продукцию цитокинов иммунокомпетентными клетками крови оценивали с помощью индекса влияния, который рассчитывали как отношение продукции цитокина клетками крови, стимулированных этими активаторами, к уровню спонтанной продукции

Маркеры костного метаболизма RANKL и OPG определяли методом ИФА с использованием тест-систем «ampli-sRANKL» и «Osteoprogerin» фирмы «Biomedica» (Австрия).

Содержание IL-12 вычисляли с помощью иммуноферментных наборов «hIL-12+p40» (BioSource Europe S.A., Бельгия), которые позволяют выполнять определение общего уровня IL-12 путем измерения биоактивного гетеродимера p35-р40 и антагониста гомодимера р40-p40; стандарты в наборе прокалиброваны по Международному стандарту 95/544 для человеческого IL-12 (NIBSC, Herfordshire, UK, EN6 3QG).

Статистический анализ полученных данных проводился с использованием пакета прикладных программ Statistica (V.6.0). Результаты исследований обрабатывали методом вариационной статистики с расчетом средней арифметической и её стандартной ошибки. Достовер-

\footnotetext{
* Инструкция по применению набора реагентов IgG общий - ИФА-БЕСТ А 8662, ЗАО «Вектор-Бест», г. Новосибирск, Россия.

** Инструкция по применению. Набор реагентов для качественного иммуноферментного определения аллергенспецифических IgG антител в сыворотке крови, «Иммунотекс», г. Ставрополь, Россия.
}

ность различий оценивали с помощью критерия $t$ Стьюдента. Различия считали достоверными при значении $p \leq 0,05$. Проводили корреляционный анализ (система парных линейных математических моделей) зависимостей «гаптен - специфический иммунный ответ». При отсутствии нормального распределения выборочных данных, при малом числе наблюдений использовали непараметрический критерий Манна-Уитни. Изучение статистических взаимосвязей проводили путем расчета коэффициентов корреляции Спирмена (rs). Характер статистического распределения по выборкам устанавливали по критерию согласия $-\chi^{2}$. Качественные данные представлены в виде абсолютных или относительных (\%) частот, количественные признаки представлены как $M \pm m$ (среднее арифметическое \pm ошибка среднего). Различия между группами считали значимыми при $p<0,05$. Проверка статистических гипотез выполнялась при критическом уровне $p \leq 0,05$.

Результаты и их обсуждение. Анализ качества воды хозяйственно-питьевого водоснабжения детских учреждений на исследуемой территории (г. Кунгур) свидетельствовал о превышении концентрации стронция относительно территории сравнения (п. Сива) в 7 раз

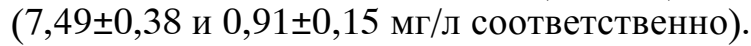

В крови детей, проживающих в зоне с повышенным содержанием стронция, установлена кратность превышения данного элемента относительно группы сравнения в 3,9 раза $(0,125 \pm 0,021$ и $0,031 \pm 0,003$ мкг $/ \mathrm{cm}^{3}$ соответственно; референт-

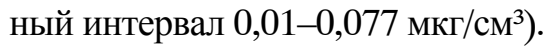

Проведенные клинико-лабораторные исследования выявили наличие патологических изменений со стороны иммунной системы школьников на исследуемой территории: установлен повышенный по сравнению с возрастной нормой уровень специфической сенсибилизации к стронцию по критерию IgG (содержание специфического $\operatorname{IgG}$ к стронцию$0,142 \pm 0,03$ усл. ед. ${ }^{*}$ при норме $\left.<0,10\right)$, в группе контроля $-0,107 \pm 0,014$.

По результатам углубленного изучения воздействия стронция на цитокинпродуцирующую активность иммунокомпетентных клеток крови детей выявлена разница в динамике стимулированной стронцием продукции медиаторов в условиях предварительной сенсибилизации стронцием и при её отсутствии (табл. 1).

* Разница достоверна по сравнению с группой контроля $(p<0,05)$. 
Таблица 1

Спонтанная и индуцированная продукция цитокинов клетками периферической крови школьников, значение медианы (25-75-й перцентиль), пг/см ${ }^{3}$ (эксперимент)

\begin{tabular}{|c|c|c|c|c|c|}
\hline \multirow{2}{*}{ Параметр } & \multirow{2}{*}{ Группа } & \multicolumn{4}{|c|}{ Цитокины } \\
\cline { 2 - 6 } & Контроль & $637,5(262,5-957,5)$ & $5,765(4,075-12,42)$ & $48,84(43,12-67,95)$ & $2,26(1,8575-2,62)$ \\
\hline \multirow{2}{*}{$\begin{array}{c}\text { Спонтанная } \\
\text { продукция }\end{array}$} & Наблюдение & $415(144-997,5)$ & $4,45(3,67-7,08)$ & $18,53(7,89-29,01)^{*}$ & $2,41(1,33-2,8)$ \\
\hline $\begin{array}{c}\text { Продукция, } \\
\text { индуцированная } \\
\text { стронцием }\end{array}$ & Контроль & $101500(81000-166750)$ & $5,61(4,1625-8,91)$ & $37,41(25,0-81,69)$ & $2,47(2,20-2,55)$ \\
\cline { 2 - 6 } & Наблюдение & $52500(39100-86325) *$ & $5(4,05-11,22)$ & $24,38(13-45,36)$ & $1,45(1,18-1,84) *$ \\
\hline \multicolumn{7}{|c|}{ Индекс влияния } \\
\hline \multirow{2}{*}{ Стронций } & Контроль & $143,38(93,58-530,92)$ & $0,90(0,54-1,51)$ & $1,03(0,61-1,42)$ & $1,04(0,89-1,39)$ \\
\cline { 2 - 6 } & Наблюдение & $201,96(55,04-423,89)$ & $1,09(0,79-2,00)$ & $1,29(0,85-1,77)$ & $0,79(0,37-1,36) *$ \\
\hline
\end{tabular}

П р и м е ч а н и е: * - разница достоверна по сравнению с группой контроля при значении $p<0,05$.

Анализ индуцируемой продукции провоспалительного IL-6, цитокина, участвующего в процессах костного ремоделирования, показал, что в обследуемой группе индуцированная стронцием продукция IL-6 достоверно ниже уровня контрольной группы. Под влиянием стронция секреция цитокина возрастает в обеих группах. При этом в обследуемой группе школьников кратность значения стимуляции (201) выше, чем у школьников контрольной группы (143). Индекс влияния стронция на синтез IL-6 как раннего медиатора, показывающего выраженную реакцию в условиях активации, превышает данный показатель остальных изучаемых цитокинов.

Не установлено влияние стронция на синтез противовоспалительного IL-10, спонтанные значения не имеют достоверного различия, но в обследуемой группе уровень данного цитокина выше, чем в контрольной, в 1,3 раза.
Спонтанный уровень провоспалительного IL-12, участвующего в дифференцировке Th0 в сторону Thl и осуществляющего клеточную защиту, в обследуемой группе ниже, чем в контрольной $(p<0,05)$. Индуцированная стронцием продукция в обеих группах не имеет достоверной разницы по сравнению со спонтанной, но более значимые изменения в выработке цитокина обнаруживаются в группе наблюдения: ИВ стронция - 1,29, в контрольной - 1,03.

Не выявляется резервный потенциал IL-17 в группе детей, имеющих предварительную сенсибилизацию стронцием, наблюдается угнетение экспрессии IL-17 после инкубации с металлом $(p<0,05)$.

Спонтанная продукция $\alpha$-TNF группы обследования статистически значимо ниже таковой в группе контроля. Уровень стронцийиндуцированной продукции данного цитокина в обследуемой группе также ниже контрольной $(p<0,05)$ (табл. 2).

Таблица 2

Спонтанная и индуцированная продукция цитокинов клетками периферической крови

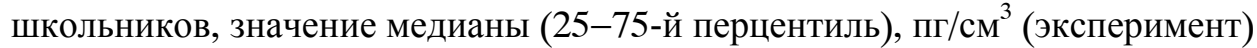

\begin{tabular}{|c|c|c|c|c|}
\hline \multirow{2}{*}{ Параметр } & \multirow{2}{*}{ Группа } & \multicolumn{3}{|c|}{ Цитокины } \\
\hline & & $\alpha$-TNF & GM-CSF & VEGF \\
\hline \multirow{2}{*}{$\begin{array}{c}\text { Спонтанная } \\
\text { продукция }\end{array}$} & Контроль & $38,69(13,19-59,66)$ & $1,25(0,85-2,38)$ & $124,71(63,82-199,56)$ \\
\hline & Наблюдение & $3,62(2,84-16,08)$ * & $1,88(0,57-4,50)$ & $84,11(28,16-170,72)$ \\
\hline \multirow{2}{*}{$\begin{array}{c}\text { Продукция, } \\
\text { индуцированная } \\
\text { стронцием }\end{array}$} & Контроль & $60,41(32,12-105,87)$ & $23,75(4,66-44,56)$ & $145,21(32,00-216,29)$ \\
\hline & Наблюдение & $7,69(3,59-20,53) *$ & $3,38(1,19-13,08) *$ & $79,73(21,21-115,39)$ \\
\hline \multicolumn{5}{|c|}{ Индекс влияния } \\
\hline \multirow{2}{*}{ Стронций } & Контроль & $1,38(0,72-4,51)$ & $26,26(4,21-52,43)$ * & $0,84(0,57-1,13)$ \\
\hline & Наблюдение & $1,26(0,86-3,63)$ & $2,26(0,99-7,77)$ & $0,62(0,44-1,66)$ \\
\hline
\end{tabular}

П р и м е ч а н и е: * - разница достоверна по сравнению с группой контроля при значении $p<0,05$. 
Концентрация GM-CSF, секретируемого спонтанно, в обеих группах не имеет достоверных различий. В условиях активации стронцием происходит стимуляция экспрессии фактора роста, однако у обследуемых детей она достоверно более низкая.

Значение медианы спонтанной концентрации эндотелиального ростового фактора VEGF у детей группы наблюдения ниже, чем в контрольной. Индуцированный синтез фактора более значим в группе контроля.

Проведены исследования влияния стронция на остеометаболизм путем определения содержания медиаторов ремоделирования костной ткани RANKL, остеопротегерина, IL-17, $\alpha$-TNF, определен дисбаланс у детей, экспонированных стронцием, между маркерами, характеризующийся соотношением RANKL/остеопротегерин, что ассоциируется со сниженной способностью поддерживать формирование и активацию остеокластов (табл. 3).

Отношение RANKL/остеопротегерин у группы наблюдения $(0,16(0,13-0,32))$ было выше аналогичного значения у детей группы контроля $(0,10(0,02-0,18))$. Также установлено изменение содержания IL-17 в кровотоке, цитокина, одной из функций которого, как маркера иммунной регуляции остеометаболизма, является индукция экспрессии RANKL. Концентрация IL-17 у детей группы наблюдения в 1,29 раза выше, чем в группе контроля. В кровотоке обследованных групп наблюдения отмечается достоверно повышенная концентрация $\alpha$-TNF по сравнению с контрольной группой.

Отмечается отрицательная корреляция $(r=-0,72 ; p<0,05)$ между содержанием стронция и уровнем остеопротегерина. Корелляционные связи между содержанием стронция и уровнем
Та блица 3

Сравнительная оценка содержания маркеров костного ремоделирования в крови школьников, значение медианы (25-75-й перцентиль), пг/ см ${ }^{3}$

\begin{tabular}{|c|c|c|}
\hline \multirow{2}{*}{ Показатель } & \multicolumn{2}{|c|}{ Группа } \\
\hline & наблюдения & контрольная \\
\hline Ampli-sRANKL, $\Pi г / \mathrm{cm}^{3}$ & $\begin{array}{c}8,48 \\
(3,52-11,71)\end{array}$ & $\begin{array}{c}5,53 \\
(1,29-13,15)\end{array}$ \\
\hline Остеопротегерин, пг/см ${ }^{3}$ & $\begin{array}{c}20,80 \\
(19,05-48,55)\end{array}$ & $\begin{array}{c}85,05 \\
(71,13-105,28) *\end{array}$ \\
\hline $\begin{array}{l}\text { Ampli-sRANKL/ } \\
\text { Остеопротегерин }\end{array}$ & $\begin{array}{c}0,16 \\
(0,13-0,32)\end{array}$ & $\begin{array}{c}0,10 \\
(0,02-0,18)\end{array}$ \\
\hline 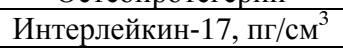 & $1,09 \pm 0,14$ & $0,85 \pm 0,12$ \\
\hline$\alpha-\mathrm{TNF}, \Pi$ пг $/ \mathrm{cm}^{3}$ & $\begin{array}{c}1,57 \\
(1,45-2,245)\end{array}$ & $\begin{array}{c}0,49 \\
(0,39-0,76) *\end{array}$ \\
\hline
\end{tabular}

П р и м е ч а н и е: * - разница достоверна по сравнению с группой наблюдения при значении $p<0,05$.

RANKL/остеопротегерин $(r=0,53 ; p<0,05)$ являются положительными.

Отношение RANKL/остеопротегерин в группе наблюдения (у школьников - 0,11) было достоверно выше аналогичного в контрольной группе $(0,06)$.

Выводы. В результате проведенных исследований установлено, что маркеры специфической гиперчувствительности и медиаторы межклеточной иммунной регуляции: $\operatorname{IgG}$ специфические к стронцию, цитокины IL-6, IL-10, IL-12, IL-17, $\alpha$-TNF, GM-CSF, спонтанные и специфически стимлированные, IL-17, $\alpha$-TNF в кровотоке, RANKL, OPG могут быть предложены для проведения идентификации риска нарушения здоровья в качестве ранних маркеров нарушений иммунорегуляции у школьников, проживающих в зонах стронциевых геохимических провинций.

\section{Список литературы}

1. Венгеровский А.И., Хлусов И.А., Нечаев К.А. Молекулярные механизмы действия бисфосфонатов и стронция ранелата // Экспер. и клин. фармак. - 2014. - Т. 77 (9). - С. $43-46$.

2. Долгих О.В., Предеина Р.А., Дианова Д.Г. Экспериментальная оценка влияния фенолов на иммунорегуляцию ех vivo // Анализ риска здоровью. - 2014. - № 1. - С. 73-81.

3. Особенности лимфоцитарно-клеточного звена у детей, проживающих на техногенно-нагруженных территориях / О.В. Долгих, Н. В. Зайцева, Д.Г. Дианова, Т.С. Лыхина, А.В. Кривцов, А.М. Гугович // Биол. мембраны. - 2012. - Т. 29 (5). - С. 349-353.

4. Approaches to the evaluation of chemical-induced immunotoxicity / K Krzystyniak [et. al.] // Environ Health Perspect. - 1995. - Vol. 103, suppl 9. - P. 17-22.

5. Caverzasio J., Thouverey C. Activation of FGF receptors is a new mechanism by which strontium ranelate induces osteoblastic cell growth // Cell. Physiol. Biochem. - 2011. - Vol. 27 (3-4). - C. 243-250.

6. Cytokine release and cytotoxicity in human keratinocytes and fibroblasts induced by phenols and sodium dodecyl sulfate / C.S. Newby [et. al.] // Journal of Investigative Dermatology. - 2000. - Vol. 115. - P. 292-298.

7. Fromigué O., Haÿ E., Barbara A. Calcium sensing receptor-dependent and receptor-independent activation of osteoblast replication and survival by strontium ranelate // JCMM. - 2009. - Vol. 13 (8B). - P. 2189-2199. 
8. Strontium enhances osteogenic differentiation of mesenchymal stem cells and in vivo bone formation by activating Wnt/catenin signaling / F. Yang, D. Yang, J. Tu, Q. Zheng, L. Cai, L. Wang // Stem cells. - 2011. - doi: 10.1002/stem.646.

9. Strontium ranelate decreases RANKL-induced osteoclastic differentiation in vitro: involvement of the calcium sensing receptor / A. Caudrillier, A.-S. Hurtel-Lemaire, A. Wattel, F. Cournarie, C. Godin, L. Petit, J.-P. Petit, E. Terwilliger, S. Kamel, E.M. Brown, R. Mentaverri, M. Brazier // Mol. pharmacol. - 2010. - Vol. 4. - P. 569-576.

10. Switching Akt: From survival signaling to deadly response / M. Los, S. Maddika, B. Erb, K. SchulzeOsthoff // BioEssays. - 2009. - Vol. 31 (5). - P. 492-495.

11. The calcium-sensing receptor is involved in strontium ranelate-induced osteoclast apoptosis. New insights into the associated signaling pathways / A.S. Hurtel-Lemaire, R. Mentaverri, A. Caudrillier, F. Cournarie, A. Wattel, S. Kamel, E.F. Terwilliger, E.M. Brown, M. Brazier // JBC. - 2009. - Vol. 284. - P. 575-584.

12. The inhibitory effect of strontium-doped calcium polyphosphate particles on cytokines from macrophages and osteoblasts leading to aseptic loosening in vitro / C. Huang, L. Li, X. Yu, Z. Gu, X. Zhang // Biomed. mater. 2014. - Vol. 9 (2). doi: 10.1088/1748-6041/9/2/025010.

13. Tucci P. Caloric restriction: is mammalian life extension linked to p53? // AGING. - 2012. - № 8. P. 525-534.

14. Wnt signaling through inhibition of $\beta$-catenin degradation in an intact axin1 complex / V.S. Li, S.S. Ng, P.J. Boersema, T.Y. Low, W.R. Karthaus, J.P. Gerlach, S. Mohammed, A.J. Heck, M.M. Maurice, T. Mahmoudi, H. Clevers // Cel. - 2012. - Vol. 149. - P. 1245-1256.

15. Yurchenko M., Shlapatska L.M., Sidorenko S.P.. The multilevel regulation of CD95 signaling outcome // Exp. oncol. - 2012. - Vol. 34 (3). - P. 200-2011.

16. Zaytseva N.V., Dianova D.G., Dolgykh O.V. Effects of cellular immunity in conditions of surplus supply of strontium with consumed water // EJNH. - 2014. - № 1. - C. 7-8.

\section{References}

1. Vengerovskiy A.I., Hlusov I.A., Nechaev K.A. Molekuljarnye mehanizmy dejstvija bisfosfonatov i stroncija ranelata [Molecular mechanisms of bisphosphonate and strontium ranelate action]. Jekcpep. i klin. fapmak, 2014, no. 77 (9), pp. 43-46.

2. Dolgikh O.V., Predeina R.A., Dianova D.G. Jeksperimental'naja ocenka vlijanija fenolov na immunoreguljaciju ex vivo [Experimental evaluation of phenol effect on ex vivo immunoregulation]. Analiz riska zdorov'ju, 2014, no. 1, pp. 73-81.

3. Dolgikh O.V., Zaitseva N. V., Dianova D.G., Lyhina T.S., Krivtsov A.V., Gugovich A.M. Osobennosti limfocitarno-kletochnogo zvena u detej, prozhivajushhih na tehnogenno-nagruzhennyh territorijah [Peculiarities of lymphocyte cell level in children living in technologically laden areas]. Biol. membrany, 2012, no. 29 (5), pp. 349-353.

4. Krzystyniak K. [et. al.] Approaches to the evaluation of chemical-induced immunotoxicity. Environ Health Perspect., 1995, vol. 103, suppl 9, pp. 17-22.

5. Caverzasio J., Thouverey C. Activation of FGF receptors is a new mechanism by which strontium ranelate induces osteoblastic cell growth. Cell. Physiol. Biochem., 2011, no. 27 (3-4), pp. 243-250.

6. Newby C.S. [et. al.] Cytokine release and cytotoxicity in human keratinocytes and fibroblasts induced by phenols and sodium dodecyl sulfate. Journal of Investigative Dermatology, 2000, vol. 115, pp. 292-298.

7. Fromigué O., Haÿ E., Barbara A. Calcium sensing receptor-dependent and receptor-independent activation of osteoblast replication and survival by strontium ranelate. JCMM, 2009, no. 13 (8B), pp. 2189-2199.

8. Yang F., Yang D., Tu J., Zheng Q., Cai L., Wang L. 2011. Strontium enhances osteogenic differentiation of mesenchymal stem cells and in vivo bone formation by activating Wnt/catenin signaling. Stem cells. 2011, doi: 10.1002/stem.646.

9. Caudrillier A., Hurtel-Lemaire A.-S., Wattel A., Cournarie F., Godin C., Petit L., Petit J.-P., Terwilliger E., Kamel S., Brown E. M., Mentaverri R., Brazier M. Strontium ranelate decreases RANKL-induced osteoclastic differentiation in vitro: involvement of the calcium sensing receptor. Mol. pharmacol, 2010, no. 4, pp. 569-576.

10. Los M., Maddika S., Erb B., SchulzeOsthoff K. Switching Akt: From survival signaling to deadly response. BioEssays, 2009, no. 31 (5), pp. 492-495.

11. Hurtel-Lemaire A.S., Mentaverri R., Caudrillier A., Cournarie F., Wattel A., Kamel S., Terwilliger E.F., Brown E.M., Brazier M. The calcium-sensing receptor is involved in strontium ranelate-induced osteoclast apoptosis. New insights into the associated signaling pathways. $J B C, 2009$, no. 284, pp. 575-584.

12. Huang C., Li L., Yu X., Gu Z., Zhang X. The inhibitory effect of strontium-doped calcium polyphosphate particles on cytokines from macrophages and osteoblasts leading to aseptic loosening in vitro. Biomed. mater, 2014, no. 9 (2). doi: 10.1088/1748-6041/9/2/025010.

13. Tucci P. Caloric restriction: is mammalian life extension linked to p53? AGING, 2012, no. 8, pp. 525-534.

14. Li V.S., Ng S.S., Boersema P.J., Low T.Y., Karthaus W.R., Gerlach J.P., Mohammed S., Heck A.J., Maurice M.M., Mahmoudi T., Clevers H. Wnt signaling through inhibition of $\beta$-catenin degradation in an intact axin1 complex. Cel., 2012, vol. 149, pp. 1245-1256. 
15. Yurchenko M., Shlapatska L.M., Sidorenko S.P. The multilevel regulation of CD95 signaling outcome. Exp. oncol., 2012, no. 34 (3), pp. 200-2011.

16. Zaytseva N.V., Dianova D.G., Dolgykh O.V. 2014. Effects of cellular immunity in conditions of surplus supply of strontium with consumed water. EJNH, no. 1, pp. 7-8.

\title{
NEUROTRANSMITTER SYSTEM OF IMMUNE REGULATION AS A MARKER OF IMMUNOLOGICAL DISORDERS IN PUPILS IN THE CONDITIONS OF INCREASED ENTRY OF STRONTIUM WITH DRINKING WATER
}

\author{
O.V. Dolgikh ${ }^{1,2}$, A.V. Krivtsov ${ }^{1}$, K.G. Starkova1, V.A. Luchnikova ${ }^{1}$, O.A. Bubnova ${ }^{1,2}$, \\ D.G. Dianova ${ }^{1}$, N.V. Bezruchenko ${ }^{1,2}$, N.A. Vdovina ${ }^{1}$ \\ ${ }^{1}$ FBSI "Federal Scientific Center for Medical and Preventive Health Risk Management Technologies", \\ Russian Federation, Perm, 82 Monastyrskaya St., 614045 \\ ${ }^{2}$ FBSEI HPE “Perm State National Research University”, Russian Federation, Perm, 15 Bukireva St., 614990
}

The evaluation of immunological markers in schoolchildren exposed to strontium is performed. It is shown that under the conditions of increased administration of strontium with drinking water the indication of spontaneous and induced levels of neurotransmitters in vitro allows to detect early functional disorders of the immune system. It was found that the following markers of specific hypersensitivity and mediators of intercellular immune regulation (IgG specific to strontium, cytokines $I L-6, I L-10, I L-12, I L-17, \alpha-T N F, G M-C S F$, spontaneous and specifically stimulated, RANKL, OPG( may be proposed for the identification of health risk as early markers of immune disorders in school children living in areas of strontium geochemical provinces.

Key words: strontium, cytokines, markers.

(C) Dolgikh O.V., Krivtsov A.V., Starkova K.G., Luchnikova V.A., Bubnova O.A., Dianova D.G., Bezruchenko N.V., Vdovina N.A., 2015

Dolgikh Oleg Vladimirovich - Doctor of Medicine, Professor, Head of Immunobiological Diagnostic Methods Department, Professor of Human Ecology and Life Safety Department (e-mail: oleg@fcrisk.ru; tel. (342) 236-39-30).

Kryvtsov Aleksandr Vladimirovich - Candidate of Medicine, Head of Immunogenetics Laboratory (e-mail: krivtsov@fcrisk.ru; tel. (342) 236-39-30).

Starkova Kseniya Gennadievna - Candidate of Medicine, Head of Immunology and Allergology Laboratory (e-mail: oleg@fcrisk.ru; tel. (342) 236-39-30).

Bubnova Olga Alekseevna - Junior Researcher, Immunobiological Diagnostic Methods Department (e-mail: oleg@fcrisk.ru; tel. (342) 236-39-30).

Dianova Dina Gumerovna - Candidate of Medicine, Senior Researcher in the Laboratory of Cellular Diagnostic Methods (e-mail: dianovadina@rambler.ru; tel. (342) 236-39-30).

Luchnikova Viktoria Aleksandrovna - Junior Researcher, Immunobiological Diagnostic Methods Department (e-mail: oleg@fcrisk.ru; tel. (342) 236-39-30).

Vdovina Nadezhda Alekseevna - Junior Researcher, Immunobiological Diagnostic Methods Department (e-mail: oleg@fcrisk.ru; tel. (342) 236-39-30).

Bezruchenko Nadezhda Vladimirovna - immunologist of Immunobiological Diagnostic Methods Department, Master's student in the Biological Faculty (e-mail: oleg@fcrisk.ru; tel. (342) 236-39-30). 


\title{
МАТЕМАТИЧЕСКАЯ МОДЕЛЬ ФУНКЦИОНИРОВАНИЯ ИММУННОЙ И НЕЙРОЭНДОКРИННОЙ СИСТЕМ С УЧЕТОМ ЭВОЛЮЦИИ НАРУШЕНИЙ СИНТЕТИЧЕСКОЙ ФУНКЦИИ ОРГАНОВ
}

\author{
Д.А. Кирьянов, Д.В. Ланин, В.М. Чигвинцев \\ ФБУН «Федеральный научный центр медико-профилактических технологий управления \\ рисками здоровью населения», Россия, 614045, г. Пермь, ул. Монастырская, 82
}

\begin{abstract}
В настоящеее время концеепция о «триединой» регуляторной «метасистеме», в которую включаются нейроэндокринный и иммунный контуры регуляции, является общепризнанной. Также хорошо известно об изменениях в каждой из регуляторных систем в ответ на воздействие техногенных химических факторов. В статье представлены математические модели функционирования иммунной и нейроэндокринной систем на примере взаимодействия этих систем в ответ на внедрение бактериального патогента. Кроме того, модели описывают изменения в работе указанных систем в условиях воздействия химических факторов, учитывая степень функционального нарушения продуцируюшего органа на примере нарушения работы костного мозга. Описанная математическая модель регуляторных систем является подмоделью «мезоуровня» и разрабатывается в рамках многоуровневой модели эволюичи функциональных нарушений, в которой индивидуальный организм предполагается состоящим из конечного числа органов и систем, взаимосвязанных между собой.

Ключевые слова: математическая модель, иммунная система, нейроэндокринная система, химические факторы, бактериальная инвазия.
\end{abstract}

Процессы регуляции в организме выполняют функцию поддержания равновесия в работе органов, тканей, клеток. В настоящее время общепризнанной является концепция о регуляторной «метасистеме», в которую включается иммунный и нейроэндокринный контуры регуляции [5]. Различные системы регуляции (иммунная и нейроэндокринная) оказывают взаимные регулирующие влияния [1]. Одной из основных функций иммунной системы считается борьба с чужеродным генетическим материалом, включая микроорганизмы и, в частности, бактерии.

Из литературы хорошо известно, что начиная с определенного возраста в организме возникают процессы «естественного старения», которые осуществляются неравномерно для разных органов и тканей, однако в общем происходит накопление различных патофизиологических нарушений, отклонений от нормативных показателей, ухудшающих эффективность функционирования организма в целом и рассматриваемых систем в частности [2]. При воздействии техногенных химических факторов происходит ускорение накопления данных нарушений и снижение эффективности функционирования регуляторных органов и систем [4]. Эти процессы, которые можно обозначить как «эволюция функциональных нарушений органов и систем», необходимо учитывать при изучении вопросов, связанных с взаимодействием данных систем.

(C) Кирьянов Д.А., Ланин Д.В., Чигвинцев В.М., 2015

Кирьянов Дмитрий Александрович - кандидат технических наук, заведующий отделом математического моделирования систем и процессов (e-mail: kda@fcrisk.ru; тел. +7 (342) 237-18-04).

Ланин Дмитрий Владимирович - кандидат медицинских наук, старший научный сотрудник лаборатории иммуногенетики (e-mail: dmlan@fcrisk.ru; тел. +7 (342) 237-18-04).

Чигвинцев Владимир Михайлович - научный сотрудник отдела математического моделирования систем и процессов (e-mail: cvm@fcrisk.ru; тел. +7 (342) 237-18-04). 
Цель исследования - математическое описание механизма регуляции, основанного на взаимодействии элементов иммунной и нейроэндокринной систем в ответ на бактериальное воздействие с учетом эволюции функциональных нарушений для последующего прогнозирования негативного влияния химических агентов, поступающих в организм из окружающей среды.

Материалы и методы. Структурная схема модели состоит из нескольких взаимосвязанных элементов нейроэндокринной и иммунной систем организма человека (рис. 1), задействованных в случае бактериальной инвазии. На каждый из них могут негативно влиять химические соединения, поступающих в организм из окружающей среды.

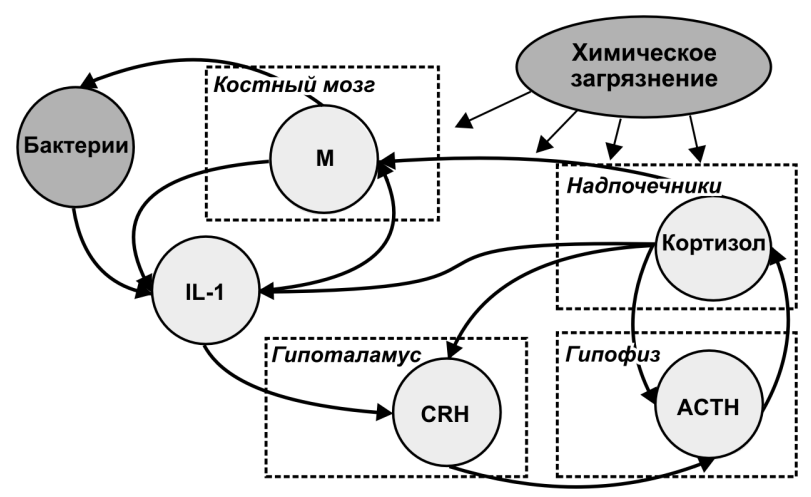

Рис. 1. Схема взаимодействия элементов иммунной и нейроэндокринной систем (в прямоугольниках обозначены органы-продуценты)

В основе механизма противодействия бактериальной инвазии лежит способность моноцитов и, в большей степени, зрелых их форм макрофагов к фагоцитозу чужеродного материала, в том числе патогенных бактерий. Так как количественное определение содержания макрофагов в организме затруднено, то оценка их содержания в исследовании производится по концентрации моноцитов в крови, которые вырабатываются костным мозгом. Поглощение комплексом «моноциты-макрофаги» (М) инфекционных агентов сопровождается синтезом и высвобождением целого ряда цитокинов, среди которых выделяется провоспалительный интерлейкин-1 (IL-1) [7]. В свою очередь появление в крови повышенного содержания IL-1, помимо многочисленных регуляторных эффектов, побуждает к мобилизации моноцитов в очаг воспаления, а также через специфические рецепторы гипоталамуса стимулирует выработку рилизинг-гормона кортиколиберина $(\mathrm{CRH})$, который, действуя на переднюю долю гипофиза, вызывает секрецию адренокортикотропного гормона (АСТН). АСТН, попадая в кровь, стимулирует надпочечники к выработке кортизола, повышение концентрации которого по механизму отрицательной обратной связи подавляет секрецию АCTH и CRH, стимулирует апоптоз «моноцитов-макрофагов» и блокирует выработку IL-1.

Взаимодействие между элементами регуляторных систем описывается набором из шести уравнений с начальными условиями и представляет собой задачу Коши, записанную для системы обыкновенных дифференциальных уравнений первого порядка с запаздывающим аргументом. Идентификация параметров модели выполнена из условий описания течения стрептококковой легочной инфекции.

Для описания явления снижения с возрастом функциональной (синтетической) активности органов (в данном случае производящих клетки или регуляторные молекулы) используется математическая модель эволюции нарушений функций органов и систем организма под воздействием факторов среды обитания $[3,6]$, согласно которой нарушение синтетической функции $j$-го органа характеризуется параметром поврежденности $D_{j} . D_{j} \in[0 ; 1]$. Значению $D_{j}=0$ соответствует нормальное (идеальное) функциональное состояние, а при $D_{j}=1$ функция органа полностью нарушена. Эволюция поврежденности определяется внешними по отношению к рассматриваемым органам воздействиями и внутренними нарушениями за счет естественных причин (старения). Под воздействиями понимаются нормированные потоки вещества, оказывающие влияние на состояние органов и систем организма.

Структура уравнений, описывающих эволюцию нарушений синтетической функции, приведена в следующем виде:

$$
\frac{d D_{j}}{d t}=a_{j} D_{j}+\sum_{i=1}^{n} b_{j i}\left\langle\frac{p_{i}}{p_{j i}^{N}}-1\right\rangle,
$$

где $a_{j}-$ коэффициент, характеризующий скорость нарушения синтетической функции (поврежденность) $j$-го органа за счет естественных причин (1/год); $b_{j i}-$ коэффициент, характеризующий интенсивность воздействия $i$-го негативного фактора на поврежденность $j$-го органа (1/год); $p_{i}$ - поток $i$-го вещества в организм человека; $p_{j i}^{N}$ - нормативное (предельно допус- 
тимое) значение потока $i$-го вещества для $j$-го органа; $\langle x\rangle$ - скобки Мак-Кейли (McCauley): $\langle x\rangle=0$ при $x<0$ и $\langle x\rangle=x$ при $x \geq 0$.

Представленная структура уравнений отражает общий вид эволюции поврежденности и учитывает процессы макроуровня - саморазрушения (естественного старения) - и накопления нарушений синтетической функции за счет ненормативных потоков веществ.

Результаты и их обсуждение. Для апробации модели поставлен численный эксперимент. В качестве примера продуцирующего органа для модели был выбран костный мозг, так как центральным звеном всех иммунных реакций в описанном примере являются производимые этим органом моноциты-макрофаги. Приведенное на рис. 2 решение отражает возможность нарушения функции костного мозга, возникающей в результате процессов естественного старения, а также комплекса воздействий «старение - химические факторы». При этом, как видно из графика, воздействие химических факторов может существенно ускорить процесс накопления нарушений синтетической функции.

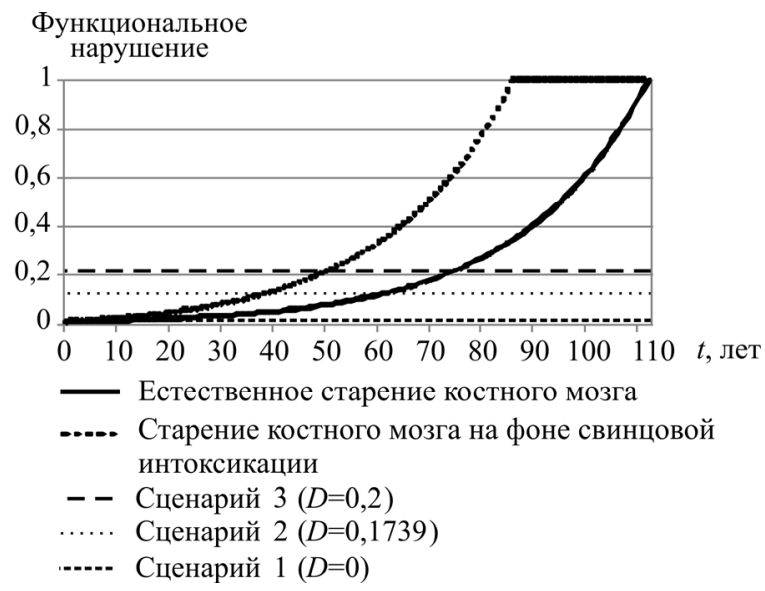

Рис. 2. Эволюция нарушения функции продукции костным мозгом моноцитов

Для проверки адекватности модели рассчитаны три сценария, отличающиеся различной степенью функционального нарушения продукции моноцитов костным мозгом, ассоциированного с воздействием химических соединений: $D=0$ (сценарий 1); $D=0,17$ (сценарий 2) и $D=0,2$ (сценарий 3). Указанные значения параметра поврежденности могут наблюдаться в различных возрастных периодах в зависимости от воздействия негативных химических факторов. Возможные решения сис- темы дифференциальных уравнений, описывающих взаимодействие иммунной и нейроэндокринной систем, приведены на рис. 3.

Каждый сценарий предполагает выведение системы из состояния равновесия, задавая начальный уровень зараженности стрептококком. На начальном этапе (в течение 2-3 суток) по всем сценариям наблюдается рост количества «макрофагов-моноцитов» и запуск регуляторных механизмов.

В первом сценарии система через 4-5 дней приходит в состояние устойчивого равновесия, что соответствует подавлению бактериального заражения и приведению показателей в нормативное состояние. В клинической практике такие изменения соответствуют либо отсутствию

Кол-во клеток

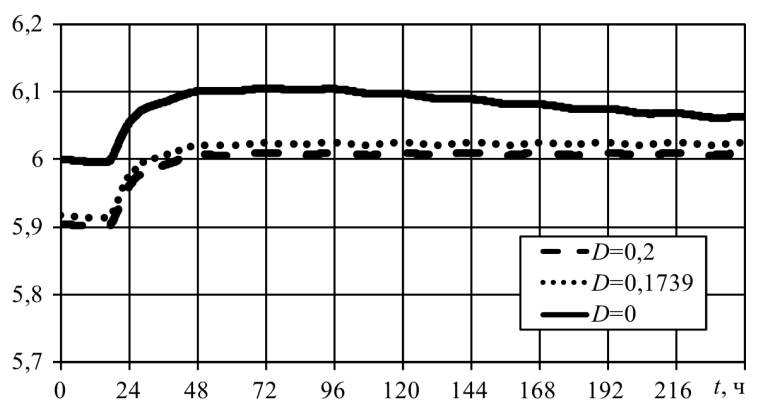

KOE $a$

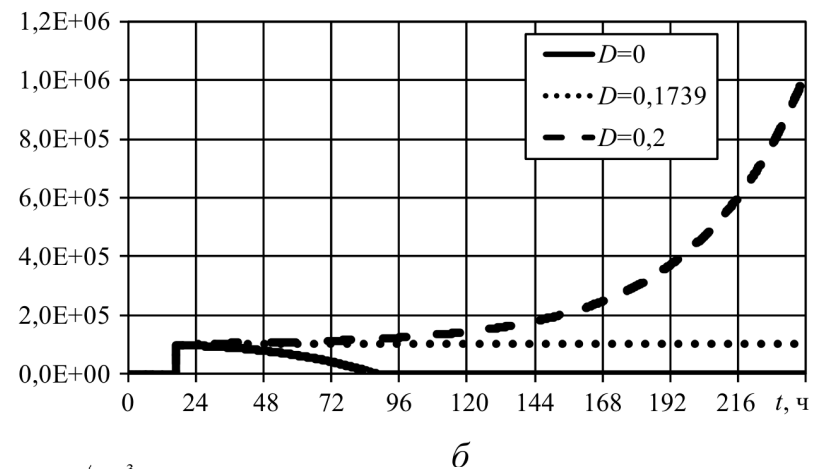

$\Pi \Gamma / \mathrm{cm}^{3}$

6

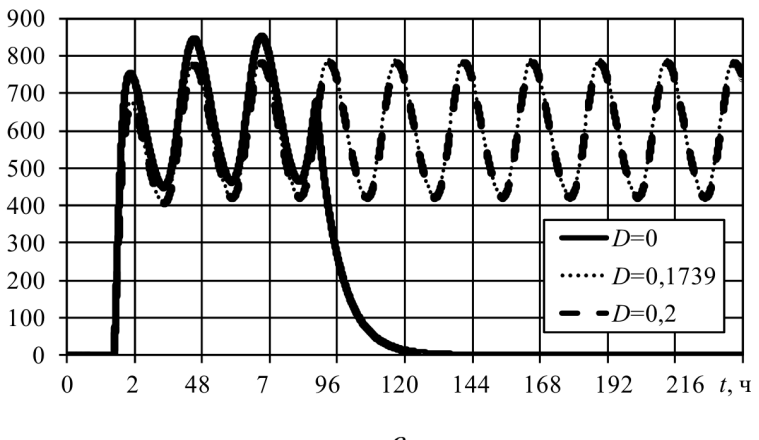

B

Рис. 3. Графики изменения: $a-$ содержания моноцитов-макрофагов, $\sigma$ - количества бактерий, 8 - концентрации IL-1 в крови 
симптоматики болезни, либо острому воспалению, заканчивающемуся быстрым выздоровлением (сценарий «санация-выздоровление»).

Второй сценарий симулирует незначительное нарушение синтетической функции костного мозга, когда осуществляется баланс двух процессов: размножения бактерий и их уничтожение макрофагами. При этом роста числа бактерий не происходит и сохраняется напряжение иммунной системы. В клинической практике примером таких состояний может быть обострение или ремиссия хронического заболевания (сценарий «хроническое заболевание»).

В третьем сценарии симулируется значительное нарушение продукции моноцитовмакрофагов костным мозгом. Изменение уровня IL-1 незначительно отличается от второго сценария, вследствие адекватной работы элементов нейроэндокринной системы. Можно наблюдать неограниченный рост числа бактерий, связанный со снижением количества моноцитов-макрофагов, что обусловлено умень- шением их продукции костным мозгом, причиной чего может быть влияние химических факторов внешней среды. Это приводит к угнетению всех регуляторных показателей, проявляющихся в тяжелых острых состояниях или при тяжелом обострении хронической инфекции (сценарий «тяжелая инфекция»), способных приводить к смерти.

Выводы. Представленная модель достаточно адекватно описывает процессы развития бактериальной инфекции с учетом воздействия химических факторов окружающей среды. Хотя исследуемая структура взаимодействия элементов иммунной и нейроэндокринной систем является далеко не полной и содержит только часть регуляторных механизмов, можно говорить о разработке базовой модели, отражающей суть многокомпонентного взаимодействия регуляторных систем при воспалительных реакциях бактериального генеза и готовой к усложнению за счет введения дополнительных параметров и связей.

\section{Список литературы}

1. Ланин Д.В., Зайцева Н.В., Долгих О.В. Нейроэндокринные механизмы регуляции функций иммунной системы // Усп. совр. биол. - 2011. - Т. 131, № 2. - С. 122-134.

2. Математическая модель эволюции функциональных нарушений в организме человека с учетом внешнесредовых факторов / П.В. Трусов, Н.В. Зайцева, Д.А. Кирьянов, М.Р. Камалтдинов, М.Ю. Цинкер, В.М. Чигвинцев, Д.В. Ланин // Математическое моделирование и биоинформатика. - 2012. - № 2. - С. $589-610$.

3. Методические подходы к оценке риска воздействия разнородных факторов среды обитания на здоровье населения на основе эволюционных моделей / Н.В. Зайцева, П.В. Трусов, П.З. Шур, Д.А. Кирьянов, В.М. Чигвинцев, Ю.П. Цинкер // Анализ риска здоровью. - 2013. - № 1. - С. 3-11.

4. Онищенко Г.Г., Зайцева Н.В., Землянова М.А. Гигиеническая индикация последствий для здоровья при внешнесредовой экспозиции химических элементов. - Пермь: Книжный формат, 2011. - 489 с.

5. Полетаев А.Б., Морозов С.Г., Ковалев И.Е. Регуляторная метасистема (иммунонейроэндокринная регуляция гомеостаза). - М.: Медицина, 2002. - 166 с.

6. Трусов П.В., Зайцева Н.В., Камалтдинов М.Р. Моделирование пищеварительных процессов с учетом функциональных нарушений в организме человека: концептуальная и математическая постановки, структура модели // Российский журнал биомеханики. - 2013. - № 4. - С. 67-83.

7. Circadian rhythm of interleukin-1 production of monocytes and the influence of endogenous and exogenous glucocorticoids in man / P. Zabel, H.J. Horst, C. Kreiler, M. Schlaak // Klin. Wocbenscbr. - 1990. - Vol. 68. C. $1217-1221$.

\section{References}

1. Lanin D.V., Zaitseva N.V., Dolgih O.V. Nejrojendokrinnye mehanizmy reguljacii funkcij immunnoj sistemy [Neuroendocrine mechanisms of regulation of the immune system functions]. Usp. sovr. biol., 2011, vol. 131, no. 2, pp. 122-134.

2. Trusov P.V., Zaitsceva N.V., Kiryanov D.A., Kamaltdinov M.R., Tsinker M.Ju., Chigvincev V.M., Lanin D.V. Matematicheskaja model' jevoljucii funkcional'nyh narushenij v organizme cheloveka s uchetom vneshnesredovyh faktorov [A mathematical model of the evolution of functional disorders in human body taking into account environmental factors]. Matematicheskoe modelirovanie i bioinformatika. 2012; 2: 589-610.

3. Zaitseva N.V., Trusov P.V., Shur P.Z., Kiryanov D.A., Chigvincev V.M., Tsinker M.Ju. Metodicheskie podhody k ocenke riska vozdejstvija raznorodnyh faktorov sredy obitanija na zdorov'e naselenija na osnove jevoljucionnyh modelej [Methodological approaches to the assessment of risk of exposure to diverse environmental factors on public health based on evolutionary models]. Analiz riska zdorov'ju, 2013, no. 1, pp. 3-11. 
4. Onishhenko G.G., Zaitseva N.V., Zemlyanova M.A. Gigienicheskaja indikacija posledstvij dlja zdorov'ja pri vneshnesredovoj jekspozicii himicheskih jelementov [Hygienic indication of health outcomes at chemicals environmental exposure]. Perm': Knizhnyj format, 2011. 489 p.

5. Poletaev A.B., Morozov S.G., Kovalev I.E. Reguljatornaja metasistema (immunonejrojendokrinnaja reguljacija gomeostaza) [Regulatory metasystem (immunoneuroendocrine regulation of homeostasis)]. Moscow: Medicina, 2002. $166 \mathrm{p}$.

6. Trusov P.V., Zaitseva N.V., Kamaltdinov M.R. Modelirovanie pishhevaritel'nyh processov s uchetom funkcional'nyh narushenij v organizme cheloveka: konceptual'naja i matematicheskaja postanovki, struktura modeli [Modelling of digestive processes with regard to functional disorders in the human body: the conceptual and mathematical statements, the model structure]. Rossijskij zhurnal biomehaniki, 2013, no. 4, pp. 67-83.

7. Zabel P., Horst H.J., Kreiler C., Schlaak M. [Circadian rhythm of interleukin-1 production of monocytes and the influence of endogenous and exogenous glucocorticoids in man]. Klin. Wocbenscbr., 1990, no. 68, pp. 1217-1221.

\section{MATHEMATICAL MODEL OF IMMUNE AND NEUROENDOCRINE SYSTEMS FUNCTIONING WITH REGARD TO EVOLUTION OF ORGAN SYNTHETIC FUNCTION VIOLATIONS}

\section{D.A. Kiryanov, D.V. Lanin, V.M. Chigvintsev}

FBSI "Federal Scientific Center for Medical and Preventive Health Risk Management Technologies", Russian Federation, Perm, 82 Monastyrskaya St., 614045

Currently, the concept of a "three-pronged" regulatory "metasystem", which includes the immune and neuroendocrine regulation circuits, is well recognized. We are also well aware of the changes in each of the regulatory systems in response to man-made chemical factors. The paper presents the mathematical model of functioning of the immune and neuroendocrine systems on the example of the interaction of these systems in response to the introduction of bacterial pathogen. In addition, the model describes the changes in these systems in terms of exposure to chemical factors, taking into account the degree of producing body functional impairment, for example, disruption of the bone marrow. The described mathematical model of regulatory systems is the "meso" level submodel and it is developed within a multi-level model of the functional disorders' evolution, in which the individual organism is assumed to consist of a finite number of interconnected organs and systems.

Key words: mathematical model, immune system, neuroendocrine system, chemical factors, bacterial invasion.

(C) Kiryanov D.A., Lanin D.V., Chigvintsev V.M., 2015

Kiryanov Dmitry Aleksandrovich - Candidate of Technical Sciences, Head of the Department of Mathematical Modeling of Systems and Processes (e-mail: kda@fcrisk.ru; tel. +7 (342) 237-18-04).

Lanin Dmitry Vladimirovich - Candidate of Medicine, Senior Researcher at the Laboratory of Immunogenetics (e-mail: dmlan@fcrisk.ru; tel. +7 (342) 237-18-04).

Chigvintsev Vladimir Mikhailovich - Researcher at the Department of Mathematical Modeling of Systems and Processes (e-mail: cvm@fcrisk.ru; tel. +7 (342) 237-18-04). 


\title{
ИЗУЧЕНИЕ ТОЛЕРАНТНОСТИ ЭНТЕРОБАКТЕРИЙ К ХЛОРСОДЕРЖАЩИМ БИОЦИДНЫМ СРЕДСТВАМ В ЭКСПЕРИМЕНТАЛЬНЫХ МОДЕЛЯХ С ИСПОЛЬЗОВАНИЕМ ХРОМОГЕННЫХ ИНДИКАТОРНЫХ ТЕСТ-СИСТЕМ
}

\author{
Н.Р. Ефимочкина, И.Б. Быкова, Ю.В. Короткевич, \\ Ю.М. Маркова, Л.П. Минаева, С.А. Шевелева
}

ФГБНУ «Научно-исследовательский институт питания», Россия, 109240, г. Москва, Устьинский проезд, 2/14

Изучен видовой состав микроорганизмов - контаминантов растительного сырья и оборудования, используемого в производстве биотехнологических продуктов и напитков брожения; выделено и изучено 85 культур энтеробактерий, из них идентифииировано до вида 46 итаммов родов Enterobacter, Pantoea, Citrobacter, Serratia, Escherichia, Cronobacter; наиболее часто обнаруживали представителей родов Enterobacter и Pantoea (около 50 \%). Впервые разработана и апробирована хромогенная модель in vitro на основе индикаторной тестсистемы, позволяющая проводить количественную оценку степени ингибирования грамотрицательной микрофлоры под воздействием антимикробных средств в зависимости от концентраций биоцидов и плотности бактериальных популяций. Сделан сравнительный анализ толерантности штаммов энтеробактерий, выделенныхх из различных биотопов; проведено тестирование чувствительности к обработке хлорсодержащими биоиидами 26 штаммов энтеробактерий из растительного сырья и 9 штаммов Escherichia coli, выделенных из кишечника крыс - самиов линии Вистар. Энтеробактерии из растительного сырья и смывов были более устойчивы к антимикробному действию хлора, нежели представители популяций нормальной кишечной микробиоты животных. Установлено, что кониентрации активного хлора 50-100 мг/дм, наиболее часто используемые при обработке растительного сырья, неэффективны для бактерий семейства Епtеrobacteriaceaе, если плотность микробной популяиии составляет $10^{5-7}$ клеток/см ${ }^{3}$ и выше. При исходном уровне контаминации энтеробактериями не более $10^{3}$ клеток/см ${ }^{3}$ обработка растворами с концентрацией активного хлора 75-100 мг/дм ${ }^{3}$ может обеспечить эффективное обеззараживание сырья, оборудования или инвентаря. Экспериментальная хромогенная модель іп vitro, предложенная для оиенки воздействия хлорсодержащих средств на степень ингибирования энтеробактерий, может быть использована для обоснования и подбора концентраций рабочих растворов антимикробных средств, эффективных в отношении других групп микробных контаминантов, что позволит оптимизировать применение режимов дезинфекции сырья и санитарной обработки оборудования на предприятиях пищевой промышленности.

Ключевые слова: энтеробактерии, хромогенная модель in vitro, растительное сырье, хлорсодержащие биоиидные средства, толерантность.

() Ефимочкина Н.Р., Быкова И.Б., Короткевич Ю.В., Маркова Ю.М., Минаева Л.П., Шевелева С.А., 2015

Ефимочкина Наталья Рамазановна - доктор биологических наук, ведущий научный сотрудник лаборатории биобезопасности и анализа нутримикробиома (e-mail: karlikanova@ion.ru; тел. 8 (495) 698-53-83; 8 (915) 366-62-59).

Быкова Ирина Борисовна - научный сотрудник лаборатории биобезопасности и анализа нутримикробиома (e-mail: bykova@ion.ru; тел. 8 (495) 698-53-83).

Короткевич Юлия Владимировна - младший научный сотрудник лаборатории биобезопасности и анализа нутримикробиома (e-mail: ulya_korotkevich@mail.ru; тел. 8 (495) 698-53-83).

Маркова Юлия Михайловна - младший научный сотрудник лаборатории биобезопасности и анализа нутримикробиома (e-mail: yulia.markova.ion@gmail.com; тел. 8 (495) 698-53-83).

Минаева Людмила Павловна - кандидат технических наук, старший научный сотрудник лаборатории биобезопасности и анализа нутримикробиома (e-mail: Liuminaeva-ion@mail.ru; тел. 8 (495) 698-53-83).

Шевелева Светлана Анатольевна - доктор медицинских наук, заведующая лабораторией биобезопасности и анализа нутримикробиома (e-mail: sheveleva@ion.ru; тел. 8 (495) 698-53-83). 
Современные эволюционные теории формирования механизмов патогенности бактерий, обеспечивающих взаимодействие возбудителя со средой обитания в соответствующих экологических нишах и сообщающих устойчивость к неблагоприятным условиям существования, являются основой для разработки новых подходов к изучению поведения пищевых бактериальных патогенов под воздействием физико-химических, технологических и иных параметров производства и хранения пищевых продуктов.

Влияние неблагоприятных воздействий внешней среды на жизненно важные функции бактериальной клетки происходит на различных регуляторных уровнях, что может приводить к появлению индуцированной толерантности микроорганизмов к воздействию тех или иных бактерицидных факторов. В природных условиях, а также при санитарной обработке воды и оборудования толерантность бактерий может формироваться под влиянием различных антибактериальных агентов, в том числе хлора, кислот, щелочей, консервантов, антиоксидантов, бактериофагов, колицинов, акрилатов, ионов металлов [1, 6, 12].

В пищевой промышленности в качестве меры, снижающей обсемененность патогенными микроорганизмами, в настоящее время достаточно широко применяют хлорсодержащие средства $[4,10,11,13]$. Свободный хлор и выделяющие его соединения (гипохлорит натрия, кальция, магния, хлорная известь, хлорамин, диоксид хло$\mathrm{pa}$, дихлоризоцианураты натрия и калия), обладая высокой антимикробной активностью против большинства болезнетворных микроорганизмов, широко используются для целей дезинфекции в медицине и ветеринарии, обеззараживания питьевой воды и очистки сточных вод, а также в производстве пищевых продуктов для обработки оборудования и снижения микробной контаминации используемого сырья.

Обработка хлорсодержащими биоцидами обеспечивает предупреждение перекрестного обсеменения продукции возбудителями пищевых инфекций и токсикоинфекций, позволяет продлить сроки годности продукции. Однако применение хлора связано с рядом негативных эффектов, одним из которых является образование тригалометанов, обладающих токсическим и канцерогенным действием: хлороформа, дихлорбромметана, дибромхлорметана и бромоформа [5, 7-9]. В целом соблюдение установленных для них максимально допустимых уровней позволяет избегать прямого риска для здоровья в виде токсических, аллергических и других реакций при употреблении пищевых продуктов и напитков с остатками таких веществ. Однако в настоящее время доказана потенциальная возможность появления как приобретенной пониженной чувствительности к биоцидам, так и устойчивости к лекарственным антимикробным средствам у микроорганизмов - контаминантов пищи и напитков [11]. С биоцидами сегодня связывают также такие негативные последствия, как ускорение эволюции бактериальных патогенов и появление новых инфекций, опасных для человека [1].

Распространение этих явлений свидетельствует о недооценке отдалённых рисков применения антимикробных средств в технологических целях. Безопасность традиционных концентраций биоцидов, используемых в пищевой индустрии, формирование толерантности к ним у различных видов контаминантов, изменение фенотипических признаков наиболее значимых групп микроорганизмов в настоящее время изучены недостаточно.

Для снижения риска негативных воздействий активного хлора важной задачей является обоснованный подбор эффективных концентраций рабочих растворов хлорсодержащих средств и оптимизация используемых режимов деконтаминации сырья и санитарной обработки оборудования на предприятиях пищевой промышленности.

В связи с изложенным проведены исследования по оценке чувствительности микроорганизмов - контаминантов биотехнологических пищевых производств к хлору и хлорсодержащим веществам на основе подбора оптимальных концентраций и технологических режимов хлорирования с целью подавления роста или уничтожения бактериальной микрофлоры семейства Enterobacteriaceae.

Для проведения исследований разработана экспериментальная хромогенная модель оценки in vitro степени ингибирования грамотрицательной микрофлоры под воздействием хлорсодержащих биоцидных средств, позволяющая количественно определять чувствительность энтеробактерий к антимикробной обработке в зависимости от концентраций хлора и плотности бактериальных популяций.

Материалы и методы. Оценку воздействия хлорсодержащих средств проводили, используя различные концентрации растворов активного хлора и суспензий тест-штаммов энтеробактерий. Эффективность антимикробного действия хлора 
оценивали по наличию или отсутствию роста штаммов в глюкозопептонной среде (ГПС) после внесения хлора и 18-часового культивирования проб при температуре $37^{\circ} \mathrm{C}$. В качестве контроля применяли те же разведения тест-культуры без добавления хлора, а также пробы неинокулированной среды ГПС.

Для обеспечения возможности варьирования двух факторов - концентрации хлора и плотности бактериальной суспензии - использовали 96-луночные стерильные иммунологические планшеты; общий объем пробы в каждой лунке составлял 200 мкл.

Предварительно во все лунки планшета вносили по 180 мкл стерильной среды ГПС, далее в первый вертикальный ряд лунок с использованием 8-канального дозатора вносили по 20 мкл суточной суспензии тест-штамма $\left(10^{9}-10^{11}\right.$ клеток/см $\left.{ }^{3}\right)$, получая первое десятикратное разведение; аналогичным образом культуру раститровывали до 11-го десятикратного разведения. Двенадцатый вертикальный ряд использовали в качестве отрицательного контроля. В горизонтальные ряды лунок вносили равные количества раствора активного хлора до получения расчетных концентраций в среде от 200 до 10 мг/дм³ . В последний ряд планшета (Н) раствор хлора не вносили.

Для визуальной оценки роста тест-штаммов в среду ГПС добавляли раствор индикатора бромтимолового синего (2 $\mathrm{cm}^{3} 1,6 \%$-ного спиртового раствора индикатора на 1 дм $^{3}$ среды), о наличии роста судили по помутнению среды и изменению ее цвета от сине-зеленого до желтого. Оптическую плотность сред измеряли с использованием автоматического планшетного фотометра «Sunrise» с длиной волны 450 нм.

Количественно чувствительность штаммов энтеробактерий к действию хлора оценивали, определяя степень ингибирования роста тестштаммов в зависимости от дозы активного хлора и исходной плотности популяции, которую выражали как разницу в титрах (количество лунок с признаками роста) в контрольных и опытных рядах планшета:

$$
\Delta i=T_{K}-T_{N}
$$

где $T_{K}$ - титр культуры без добавления хлора, $T_{N}-$ титр культуры с соответствующей дозой хлора $(N)$.

В качестве хлорсодержащего препарата использовали дезинфицирующее средство, содержащее натриевую соль дихлоризоциануровой кислоты. Рабочие растворы с различными концентрациями активного хлора готовили непосредственно перед экспериментом.

Для разработки модели применяли тестштаммы Salmonella enteritidis 874 из коллекции ФГБНУ «Научно-исследовательский институт питания», S.typhimurium NCTC 00074 и Escherichia coli 1330 серотипа O157: Н7 из коллекции ГИСК им. Л.А.Тарасевича. Объектами исследований в хромогенных моделях in vitro являлись штаммы бактерий семейства Enterobacteriaceae, выделенные из растительного сырья (картофеля, зерновых культур, солода) и смывов с поверхностей оборудования пивоваренного производства. Видовую принадлежность выделенных штаммов энтеробактерий устанавливали при использовании биохимических тест-систем «API 20E», «Rapid 20E», «API $10 \mathrm{~S} », \quad$ («БиоМерье», Франция). Кроме того, в качестве модельных тест-объектов были использованы штаммы E.coli, выделенные из кишечника лабораторных животных (крыс-самцов линии Вистар). Видовую принадлежность выделенных штаммов устанавливали при использовании биохимических тест-систем «АРI 20E», «Rapid 20E», «API 10S» («БиоМерье», Франция). Всего в эксперименте было протестировано 87 культур энтеробактерий.

Результаты и их обсуждение. Схема двухфакторного модельного эксперимента с тестированием коллекционного штамма E.coli 1330 приведена в табл. 1. В данном случае in vitro было показано, что концентрации активного хлора 50 и 100 мг/дм³, наиболее часто используемые для обеззараживания питьевой воды и обработки растительного сырья, неэффективны для патогенных бактерий семейства Enterobacteriaceae, если плотность микробной по-

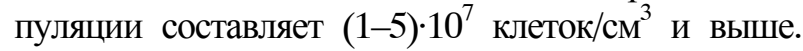
При этом сальмонеллы выживали и при исходной концентрации $10^{5}-10^{6}$ клеток/см ${ }^{3}$ (рис. 1).

С использованием хромогенной модели была изучена чувствительность к хлору у тестштаммов кишечных палочек, выделенных из нормальной микрофлоры кишечника лабораторных животных. Для исследований было отобрано 9 типичных штаммов E.coli, идентифицированных по комплексу культуральных и биохимических тестов с использованием наборов API 10S. Толерантность к воздействию хлора у культур E.coli, выделенных из микробиоты лабораторных животных (табл. 3), была сопоставима с чувствительностью коллекционного штамма E.coli серотипа О157: Н7, тогда как степень ингибирования сальмонелл в тех же условиях была значительно ниже (табл. 2). 
Т а б ли ц 1

Оценка воздействия хлора на культуру Escherichia coli 1330

\begin{tabular}{|c|c|c|c|c|c|c|c|c|c|c|c|c|}
\hline \multirow{2}{*}{$\begin{array}{c}\text { Дозы активного } \\
\text { хлора, мг/дм }\end{array}$} & \multicolumn{10}{|c|}{ Оптическая плотность проб, 450 нм } \\
\hline & $1 \mathrm{p}$ & $2 \mathrm{p}$ & $3 \mathrm{p}$ & $4 \mathrm{p}$ & $5 \mathrm{p}$ & $6 \mathrm{p}$ & $7 \mathrm{p}$ & $8 \mathrm{p}$ & $9 \mathrm{p}$ & $10 \mathrm{p}$ & $11 \mathrm{p}$ & ОК \\
\hline 200 & 0,495 & 0,492 & 0,424 & 0,416 & 0,426 & 0,405 & 0,412 & 0,420 & 0,414 & 0,417 & 0,412 & 0,460 \\
\hline 150 & 1,120 & 0,480 & 0,395 & 0,388 & 0,392 & 0,385 & 0,392 & 0,391 & 0,413 & 0,404 & 0,396 & 0,442 \\
\hline 100 & 0,965 & 0,805 & 0,381 & 0,346 & 0,352 & 0,360 & 0,337 & 0,349 & 0,354 & 0,359 & 0,351 & 0,370 \\
\hline 75 & 1,089 & 0,889 & 0,376 & 0,336 & 0,345 & 0,342 & 0,339 & 0,345 & 0,334 & 0,332 & 0,324 & 0,364 \\
\hline 50 & 1,051 & 0,828 & 0,589 & 0,341 & 0,356 & 0,338 & 0,330 & 0,325 & 0,321 & 0,309 & 0,306 & 0,335 \\
\hline 25 & 0,954 & 0,710 & 0,652 & 0,627 & 0,612 & 0,598 & 0,323 & 0,394 & 0,301 & 0,290 & 0,287 & 0,315 \\
\hline 10 & 0,908 & 0,745 & 0,625 & 0,620 & 0,641 & 0,619 & 0,613 & 0,642 & 0,269 & 0,265 & 0,261 & 0,291 \\
\hline $\mathrm{K}$ & 1,034 & 0,753 & 0,663 & 0,659 & 0,675 & 0,639 & 0,645 & 0,488 & 0,465 & 0,288 & 0,272 & 0,284 \\
\hline
\end{tabular}

П р и м е ч а н и е: цветом выделены лунки планшета / значения ОП, в которых регистрировали увеличение мутности и изменение цвета среды.

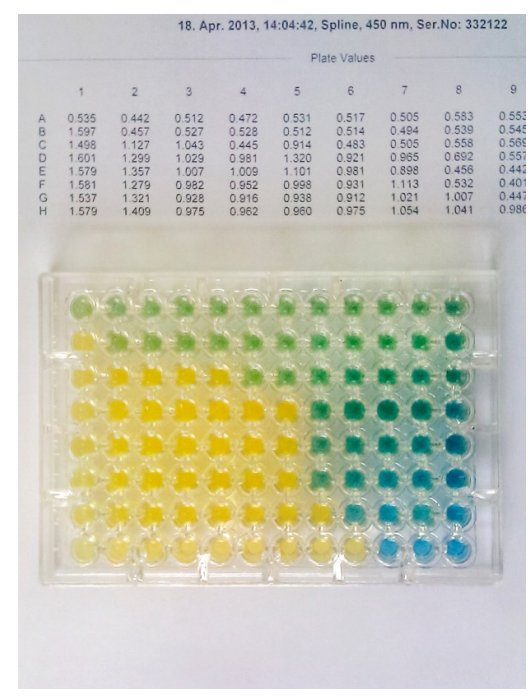

S. enteritidis

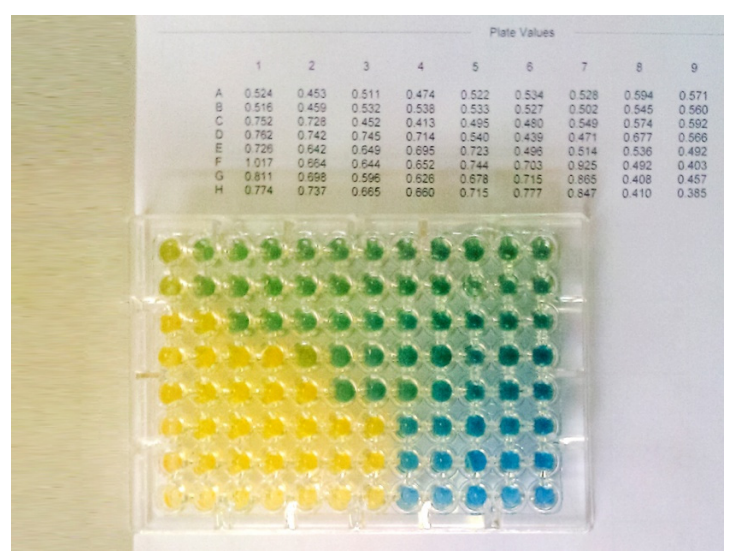

S. typhimurium

Рис. 1. Рост коллекционных тест-штаммов сальмонелл в экспериментальной хромогенной модели с использованием 96-луночного планшета

Таблица 2

Степень ингибирования тест-штаммов $E$. coli при различных концентрациях активного хлора

\begin{tabular}{|c|c|c|c|c|c|c|c|c|}
\hline \multirow{2}{*}{$\begin{array}{c}\text { Номер } \\
\text { штамма }\end{array}$} & Исходный титр & \multicolumn{5}{|c|}{ Концентрация активного хлора в среде, мг/дм } \\
\cline { 3 - 8 } \\
\cline { 3 - 8 }
\end{tabular}


В данном эксперименте in vitro показано, что концентрации активного хлора 150-200 мг/дм ${ }^{3}$ обладают выраженным бактерицидным действием в отношении E. coli, приводя к практически полной инактивации живых клеток при их содержании до $10^{8} \mathrm{KOE} / \mathrm{cm}^{3}$. При дозировке активного хлора в растворе 75-100 мг/дм ${ }^{3}$ происходит снижение числа живых клеток на 1,1-2,7 порядка, а внесение хлора в дозах менее 50 мг/дм ${ }^{3}$ было малоэффективным при любой плотности бактериальных суспензий.

Микробиологические исследования растительного сырья и санитарных условий пищевых биотехнологических производств включали оценку количественных уровней бактериальной контаминации, анализ видового состава, изучение фенотипических свойств выделенных штаммов и чувствительность их к антимикробным воздействиям.

При исследовании 13 образцов солода, зерна и смывов с оборудования предприятий по производству напитков брожения было выделено 32 культуры грамотрицательных аэробных и факультативно анаэробных бактерий, подвергнутых идентификации по расширенному перечню культуральных и биохимических тестов. Из общего числа выделенных штаммов 27 культур были идентифицированы; 26 штаммов принадлежали к различным родам в составе семейства Enterobacteriaceae, 1 культура Pseudomonadoceae. В пробах были обнаружены бактерии родов Enterobacter, Pantoea, Citrobacter, Serratia, Pseudomonas, Klebsiella, Escherichia. Из общего числа выделенных штаммов видовая принадлежность была установлена для 17 культур, которые относились к видам Enterobacter cloacae, E. amnigenus, E.aerogenes, Serratia fonticola, S.ficaria, Citrobacter freundii, Klebsiella pneumoniae, Escherichia coli, Pseudomonas aerugi$n o s a$. Анализ видового состава изолятов показал, что наибольшее число штаммов - 11 культур (42\%) - было представлено бактериями рода Pantoea. Микроорганизмы рода Pantoea обнаруживались в большинстве исследованных проб. Второй по частоте обнаружения группой микроорганизмов, выделенных из смывов и сырья, были бактерии рода Enterobacter $(29,6 \%$ всех штаммов). Сопоставление данных о частоте обнаружения колиформных лактозоположительных бактерий и других грамотрицательных микроорганизмов позволило выявить существенные различия в составе контаминантов сырья и смывов: колиформы значительно чаще обнаруживались в смывах, а энтеробактерии растительного происхождения - в солоде.
При изучении видового состава микрофлоры, контаминирующей крахмалсодержащее сырье для спиртового производства (пробы цельного и дробленого зерна пшеницы, ячменя, овса, клубни картофеля, полученные из нескольких регионов Российской Федерации, а также по импорту, всего 17 проб), было выделено 53 штамма грамотрицательных, ферментирующих глюкозу бактерий. По результатам идентификации принадлежность семейству Enterobacteriaceae подтверждена для 29 штаммов, в том числе были обнаружены условно-патогенные бактерии родов Enterobacter, Pantoea, Citrobacter, Serratia, Escherichia. В двух случаях выделены патогенные микроорганизмы рода Cronobacter. Наиболее часто обнаруживали представителей родов Enterobacter $(38,0 \%)$ и Pantoea $(27,6 \%)$. Колиформные лактозоположительные бактерии (БГКП) фиксировали как в зерне, так и в картофеле, а энтеробактерии растительного происхождения Pantoea spp. были выделены только из зернового сырья.

Перечень штаммов энтеробактерий, отобранных для тестирования в экспериментальной хромогенной модели in vitro, приведен в табл. 3.

Результаты сравнительной оценки чувствительности к хлору 26 штаммов бактерий, выделенных из растительного сырья и смывов с производственного оборудования, приведены в табл. 4.

Анализ полученных данных показал, что все исследованные штаммы энтеробактерий в той или иной степени были чувствительны к использованным в эксперименте концентрациям активного хлора. Дозы 200 и 150 мг/дм ${ }^{3}$ полностью подавляли рост 7 из 26 исследованных штаммов $(26,9 \%)$. При концентрации активного хлора 75-100 мг/дм ${ }^{3}$ наблюдали значительное ингибирование роста штаммов

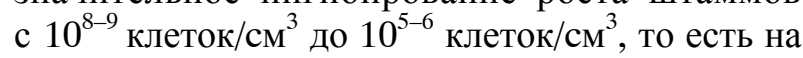
3,5-4,7 логарифмических порядка. При меньших концентрациях хлора ингибирования практически не происходило - плотность популяций снижалась лишь в 5-10 раз (менее $1,0 \mathrm{lg}$ клеток $\left./ \mathrm{cm}^{3}\right)$.

Сравнение чувствительности к хлору бактерий семейства Enterobacteriaceae, выделенных из смывов и растительного сырья, и штаммов E. coli из кишечника крыс показало, что при концентрациях хлора 75-100 мг/дм ${ }^{3}$ бактерии, выделенные из растительного сырья, были менее чувствительны к антимикробному действию хлорсодержащих средств (рис. 2). 
Видовая принадлежность исследованных штаммов энтеробактерий

\begin{tabular}{|c|c|c|}
\hline Номер штамма & Видовая принадлежность & Источник выделения \\
\hline \multicolumn{3}{|c|}{ Лактозоположстельные энтеробактерии (БГКП) } \\
\hline $5 / 6$ & Escherichia coli & Солод ржаной неферментированный \\
\hline 1 & Citrobacter freundii & Пшеница \\
\hline $6 / 4$ & Citrobacter freundii & Смыв (разливочный аппарат) \\
\hline 24 & Citrobacter freundii & Пшеница \\
\hline 50 & Citrobacter braakii & Картофель \\
\hline $1 / 3$ & Klebsiella pneumonia & Солод ячменный \\
\hline 14 & Enterobacter spp & Пшеница \\
\hline $7 / 4$ & Enterobacter cloacae & Смыв с дозатора (укупорка) \\
\hline $7 / 6$ & Enterobacter cloacae & Смыв с дозатора (укупорка) \\
\hline 16 & Enterobacter cloacae & Овес \\
\hline 22 & Enterobacter cloacae & Пшеница \\
\hline 41 & Enterobacter cloacae & Картофель \\
\hline 48 & Enterobacter cloacae & Картофель \\
\hline 52 & Enterobacter cloacae & картофель \\
\hline 47 & Cronobacter spp (E. sakazakii) & Картофель \\
\hline 51 & Cronobacter spp (E. sakazakii) & Картофель \\
\hline \multicolumn{3}{|c|}{ Лактозонегативные энтеробактерии } \\
\hline $2 / 1$ & Pantoea spp. & Рожь \\
\hline $2 / 3$ & Pantoea spp. & Рожь \\
\hline $3 / 1$ & Pantoea spp. & Солод пшеничный \\
\hline 20 & Pantoea spp. & Ячмень \\
\hline 30 & Pantoea spp. & Пшеница \\
\hline 33 & Pantoea spp. & Пшеница \\
\hline 38 & Serratia ficaria & Картофель \\
\hline 45 & Serratia marcescens & Картофель \\
\hline 35 & Leclercia adecarboxylata & Пшеница \\
\hline \multicolumn{3}{|c|}{ Другие виды лактозонегативных бактерий } \\
\hline $6 / 6$ & Pseudomonas aeruginosa & Смыв (разливочный аппарат) \\
\hline
\end{tabular}

Таблица 4

Степень ингибирования штаммов, выделенных из растительного сырья и смывов $(\Delta i)$

\begin{tabular}{|c|c|c|c|c|c|c|c|c|}
\hline \multirow{2}{*}{$\begin{array}{c}\text { Номер } \\
\text { штамма }\end{array}$} & \multirow{2}{*}{$\begin{array}{c}\text { Исходный титр } \\
\text { культуры }\end{array}$} & \multicolumn{7}{|c|}{ Концентрация активного хлора в среде, мг/дм ${ }^{3}$} \\
\hline & & 200 & 150 & 100 & \begin{tabular}{|l|l}
75 & \\
\end{tabular} & 50 & 25 & 10 \\
\hline \multicolumn{9}{|c|}{ Лактозоположительные энтеробактерии (БГКП) } \\
\hline $5 / 6$ & 9 & \begin{tabular}{|l|l}
9 &
\end{tabular} & 9 & 6 & 2 & 2 & 0 & 0 \\
\hline 1 & 9 & 9 & 9 & 8 & 8 & 3 & 2 & 1 \\
\hline $6 / 4$ & 9 & 8 & 8 & 6 & 1 & 1 & 0 & 0 \\
\hline 24 & 9 & 9 & 9 & 8 & 9 & 1 & 2 & 0 \\
\hline 50 & 8 & 7 & 7 & 2 & 1 & 1 & 0 & 0 \\
\hline $1 / 3$ & 8 & 7 & 7 & 6 & 6 & 0 & 0 & 0 \\
\hline 14 & 9 & 9 & 8 & 7 & 7 & 1 & 0 & 0 \\
\hline $7 / 4$ & 9 & 8 & 7 & 5 & 3 & 1 & 1 & 0 \\
\hline $7 / 6$ & 9 & 7 & 7 & 6 & 5 & 1 & 0 & 0 \\
\hline 16 & 11 & 10 & 11 & 9 & 10 & 3 & 2 & 2 \\
\hline 22 & 10 & 10 & 10 & 8 & 7 & 3 & 0 & 2 \\
\hline 41 & 9 & 8 & 6 & 0 & 0 & 0 & 1 & 0 \\
\hline 48 & 9 & 7 & 0 & 1 & 1 & 1 & 0 & 1 \\
\hline 52 & 10 & 9 & 8 & 2 & 2 & 0 & 2 & 2 \\
\hline 47 & 8 & 6 & 6 & 1 & 1 & 0 & 1 & 0 \\
\hline 51 & 8 & 7 & 7 & 1 & 1 & 0 & 0 & 0 \\
\hline $2 / 1$ & 9 & 7 & 7 & 6 & 5 & 1 & 0 & 0 \\
\hline$(M) \pm$ стд. ошибка среднего & $9,00 \pm 0,19$ & $8,06 \pm 0,29$ & $7,41 \pm 0,57$ & $4,82 \pm 0,72$ & $4,06 \pm 0,79$ & $1,12 \pm 0,26$ & $0,65 \pm 0,21$ & $0,47 \pm 0,19$ \\
\hline Медиана & 9,0 & \begin{tabular}{|l|l}
8,0 \\
\end{tabular} & 7,0 & 6,0 & \begin{tabular}{|l|}
3,0 \\
\end{tabular} & 1,0 & 0,0 & 0,0 \\
\hline \multicolumn{9}{|c|}{ Лактозонегативные энтеробактерии и Pseudomonas spp. } \\
\hline $2 / 3$ & 9 & \begin{tabular}{|l|l}
8 &
\end{tabular} & 8 & 7 & \begin{tabular}{|l|l}
7 & \\
\end{tabular} & 3 & 1 & 1 \\
\hline $3 / 1$ & 8 & 7 & 7 & 5 & 3 & 2 & 0 & 0 \\
\hline
\end{tabular}


Окончание табл. 4

\begin{tabular}{|c|c|c|c|c|c|c|c|c|}
\hline \multirow{2}{*}{$\begin{array}{c}\text { Номер } \\
\text { штамма }\end{array}$} & \multirow{2}{*}{$\begin{array}{c}\text { Исходный титр } \\
\text { культуры }\end{array}$} & \multicolumn{7}{|c|}{ Концентрация активного хлора в среде, мг/дм ${ }^{3}$} \\
\hline & & 200 & 150 & 100 & 75 & 50 & 25 & 10 \\
\hline 20 & 9 & 9 & 9 & 9 & 6 & 2 & 1 & 0 \\
\hline 30 & 8 & 8 & 8 & 2 & 2 & 1 & 1 & 1 \\
\hline 33 & 8 & 7 & 8 & 1 & 1 & 1 & 0 & 0 \\
\hline 38 & 8 & 7 & 3 & 0 & 0 & 0 & 0 & 0 \\
\hline 45 & 8 & 7 & 6 & 0 & 0 & 0 & 0 & 0 \\
\hline 35 & 7 & 7 & 4 & 2 & 1 & 1 & 1 & 0 \\
\hline $6 / 6$ & 8 & 3 & 2 & 0 & 0 & 0 & 0 & 0 \\
\hline $\begin{array}{c}(M) \pm \text { стд. ошибка } \\
\text { среднего }\end{array}$ & $8,11 \pm 0,20$ & $7,00 \pm 0,55$ & $6,11 \pm 0,84$ & $2,89 \pm 1,11$ & $2,22 \pm 0,88$ & $1,11 \pm 0,35$ & $0,44 \pm 0,18$ & $0,22 \pm 0,15$ \\
\hline Медиана & 8,0 & 7,0 & 7,0 & 2,0 & 1,0 & 1,0 & 0,0 & 0,0 \\
\hline 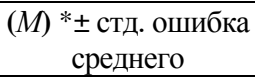 & $8,69 \pm 0,22$ & $7,80 \pm 0,22$ & $6,94 \pm 0,42$ & $3,77 \pm 0,51$ & $2,83 \pm 0,50$ & $1,09 \pm 0,18$ & $0,66 \pm 0,14$ & $40,34 \pm 0,11$ \\
\hline Медиана & 9,0 & 8,00 & 8,00 & 2,00 & 1,00 & 1,00 & 0,00 & 0,00 \\
\hline
\end{tabular}

П р и м е ч а н и е: * - средние значения для всех протестированных штаммов.

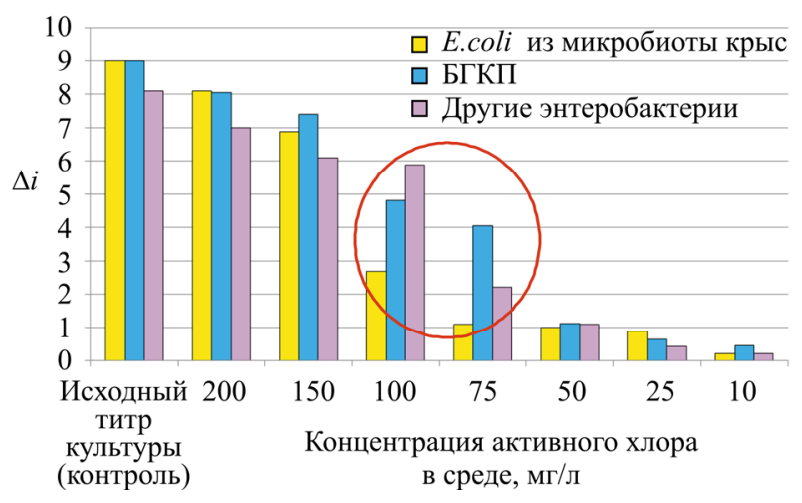

Рис. 2. Степень толерантности к хлору у E.coli и энтеробактерий, выделенных из смывов и растительного сырья

Наиболее выраженной толерантностью к хлору обладали энтеробактерии рода Pantoea, которые обычно персистируют в биотопах растительных и почвенных экосистем, являясь одним из самых распространенных представителей семейства Enterobacteriaceae [2]. Так, выделенные из зерна пшеницы штаммы Pantoea spp. № 30 и № 35 были устойчивы к воздействию 100-150 мг/дм ${ }^{3}$ активного хлора, степень ингибирования при этих условиях была на 3 логарифмических порядка ниже по сравнению с другими выделенными штаммами (см. табл. 4, рис. 3).

Чувствительность к хлору колиформных бактерий (БГКП) из растительного сырья в сравнении с другими представителями семейства Enterobacteriaceae в некоторых случаях была более выражена, однако достоверной разницы при небольшом объеме выборки выявить не удалось.

Существующая практика обеззараживания питьевой воды предполагает подбор дозировок активного хлора таким образом, чтобы по мик-

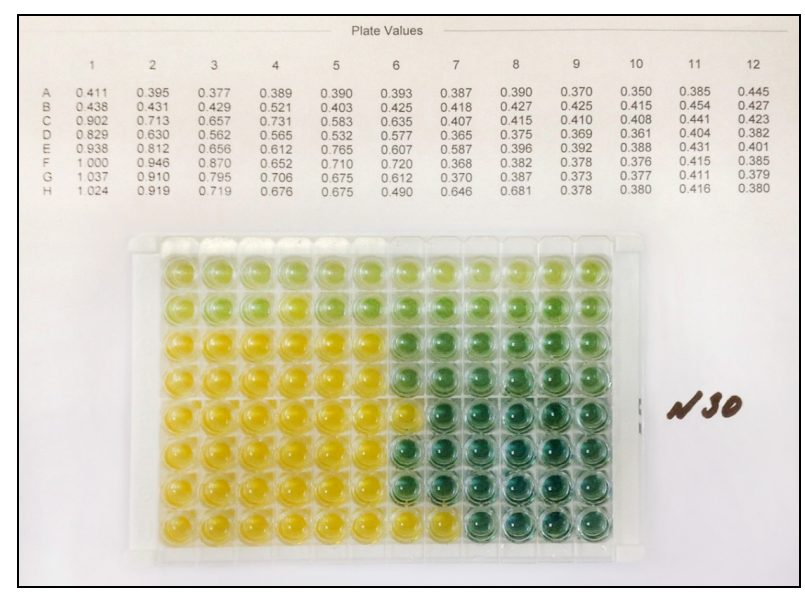

$a$

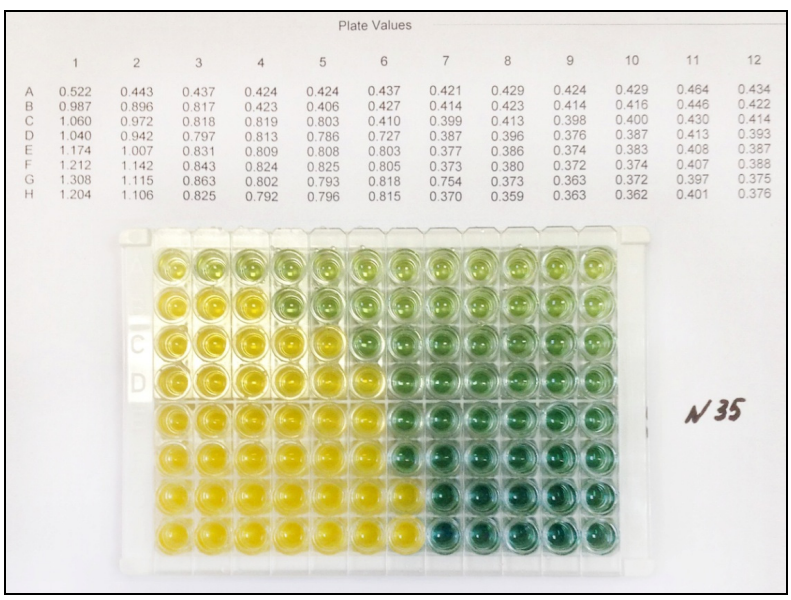

$\sigma$

Рис. 3. Рост Pantoea spp. в хромогенной модели при различных концентрациях активного хлора: $a$ - штамм № 30; $\sigma$ - штамм № 35

робиологическим показателям она соответствовала требованиям СанПиН 2.1.4.1074-01 [3], а содержание остаточного хлора при этом не 
превышало 0,3-0,5 мг/дм³. Наиболее часто для этих целей используются концентрации активного хлора от 50 до 100 мг/дм ${ }^{3}$ при различной продолжительности обработки (экспозиции).

В осуществленном эксперименте при концентрации активного хлора $100 \mathrm{мг/д^{3 }}$ в модельной среде достигалось снижение плотности бактериальных популяций в среднем на 5 логарифмических порядков, а при 75 мг/дм ${ }^{3}-$ на 3-4 порядка. Исключение составили данные относительно штамма Ps. aeruginosa 6/6, выделенного из смыва с оборудования: ингибирование культуры достигалось только при содержании активного хлора 150-200 мг/ дм³ ${ }^{3}$ штамм был практически нечувствителен к более низким концентрациям.

\section{Выводы:}

1. Изучен видовой состав микробных контаминантов растительного сырья и оборудования, используемого в производстве биотехнологических продуктов и напитков брожения; выделено и изучено по комплексу культурально-биохимических показателей 85 культур энтеробактерий, из них идентифицировано до вида 46 штаммов родов Enterobacter, Pantoea, Citrobacter, Serratia, Escherichia, Cronobacter; наиболее часто обнаруживали представителей родов Enterobacter и Pantoea (около $50 \%$ ).

2. Впервые разработана и апробирована в экспериментальных условия х хромогенная модель in vitro на основе индикаторной тестсистемы, позволяющая проводить количественную оценку степени ингибирования грамотрицательной микрофлоры под воздействием антимикробных средств в зависимости от концентраций биоцидов и плотности бактериальных популяций.
3. С использованием разработанной модели сделан сравнительный анализ толерантности штаммов энтеробактерий, выделенных из различных биотопов; проведено тестирование чувствительности к обработке хлорсодержащими биоцидными средствами 26 штаммов - контаминантов растительного сырья и 9 штаммов E. coli, выделенных из кишечника лабораторных животных. Энтеробактерии из растительного сырья и смывов были более устойчивы к антимикробному действию хлора, нежели представители популяций нормальной кишечной микробиоты.

4. Показано, что концентрации активного хлора 50-100 мг/дм ${ }^{3}$, наиболее часто используемые при обработке растительного сырья, неэффективны для бактерий семейства Enterobacteriaceae, если плотность микробной популяции составляет $10^{5-7}$ клеток/см ${ }^{3}$ и выше. При исходном уровне контаминации энтеробактериями не более $10^{3}$ клеток/см ${ }^{3}$ обработка растворами с концентрацией активного хлора 75-100 мг/дм ${ }^{3}$ может обеспечить эффективное обеззараживание сырья, оборудования или инвентаря.

5. Экспериментальная хромогенная модель in vitro, предложенная для оценки воздействия хлорсодержащих средств на степень ингибирования энтеробактерий, может быть использована для обоснования и подбора концентраций рабочих растворов антимикробных средств, эффективных в отношении других групп микробных контаминантов, что позволит оптимизировать применение режимов дезинфекции сырья и санитарной обработки оборудования на предприятиях пищевой промышленности.

\section{Список литературы}

1. Ефимочкина Н.Р. Микробиология пищевых продуктов и современные методы детекции патогенов. - М.: Изд-во РАМН, 2013. - 517 с.

2. Изучение особенностей микробной контаминации свежих овощей и листовых салатов промышленного изготовления / Н.Р. Ефимочкина, И.Б. Быкова, С.Ю. Батищева, Л.П. Минаева, Ю.М. Маркова, Ю.В. Короткевич, Г.Ю. Шилов, С.А. Шевелева // Вопросы питания. - 2014. - № 5. - С. 33-42.

3. СанПиН 2.1.4.1074-01. Питьевая вода. Гигиенические требования к качеству воды централизованных систем питьевого водоснабжения. Контроль качества. Гигиенические требования к обеспечению безопасности систем горячего водоснабжения. Санитарно-эпидемиологические правила и нормативы. - М.: Роспотребнадзор, 2001. - 112 с.

4. Application of Acidified Sodium Chlorite in the Drinking Water to Control Salmonella serotype Typhimurium and Campylobacter jejuni in Commercial Broilers / P. Mohyla, S.F. Bilgili, O.A. Oyarzabal [et al.] // J. Appl. Poult Res. - 2007. - Vol. 16, № 1. - P. 45-51. doi: 10.1093/japr/16.1.45

5. Biodisposition of dibromoacetic acid (DBA) and bromodichloromethane (BDCM) administered to rats and rabbits in drinking water during range-finding reproduction and developmental toxicity studies / M.S. Christian, R.G. York, A.M. Hoberman [et al.] // International Journal of Toxicology. - 2001. - Vol. 20. - P. 239-253. 
6. Hicks S.J., Rowbury R.J. Resistance of attached Escherichia coli to acrylic acid and its significance for the survival of plasmid-bearing organisms in water // Ann. Inst. Pasteur. - 1987. - Vol. 138. - P. 359-369.

7. International Life Sciences Institute. An Evaluation of EPA's Proposed Guidelines for Carcinogen Risk Assessment Using Chloroform and Dichloroacetate as Case Studies. Report of an Expert Panel, ILSI HESI, Washington, DC, November, 1997. - $240 \mathrm{c}$.

8. Oral (drinking water) developmental toxicity studies of bromodichloromethane (BDCM) in rats and rabbits / M.S. Christian, R.G. York, A.M. Hoberman [et al.] // International Journal of Toxicology. - 2001. - Vol. 20. P. 225-237.

9. Oral (drinking water) two-generation reproductive toxicity study of bromodichloromethane (BDCM) in rats / M.S. Christian, R.G. York, A.M. Hoberman [et al.] // International Journal of Toxicology. - 2002. - Vol. 21. - P. 115-146.

10. Oyarzabal O.A. Reduction of Campylobacter spp. by commercial antimicrobials applied during the processing of broiler chickens: a review from the United States perspective // J. Food Prot. - 2005. - Vol. 68. - P. $1752-1760$.

11. Scientific Opinion of the Panel on Biological Hazards on a request from DG SANCO on the assessment of the possible effect of the four antimicrobial treatment substances on the emergence of antimicrobial resistance // The EFSA Journal. - 2008. - Vol. 659. - P. 1-26.

12. Whiting G.C., Rowbury R.J. Increased resistance of Escherichia coli to acrylic acid and to copper ions after cold-shock // Letts. Appl. Microbiol. - 1995. - Vol. 20. - P. 240-242.

13. Yang H., Li Y. Johnson M.G. Survival and death of Salmonella typhimurium and Campylobacter jejuni in processing water and on chicken skin during poultry scalding and chilling // J. Food Prot. - 2001. - Vol. 64. P. 770-776.

\section{References}

1. Efimochkina N.R. Mikrobiologija pishhevyh produktov i sovremennye metody detekcii patogenov [Food microbiology and modern methods of detection of foodborne pathogens]. Moscow: Publishing house of the Russian Academy of Medical Sciences, 2013. 517 p.

2. Efimochkina N.R., Bykova I.B., Batisheva S.Yu., Minaeva L.P., Markova Yu.M., KorotkevichYu.V., Shilov G.Yu., ShevelevaS.A. Izuchenie osobennostej mikrobnoj kontaminacii svezhih ovoshhej i listovyh salatov promyshlennogo izgotovlenija [Study of microbial contamination of processed fresh vegetables and lettuce]. Voprosi pitanya, 2014, no. 5, pp. 33-42 (In Russan).

3. SanPiN 2.1.4.1074-01. «Pit'evaja voda. Gigienicheskie trebovanija k kachestvu vody centralizovannyh sistem pit'evogo vodosnabzhenija. Kontrol' kachestva. Gigienicheskie trebovanija k obespecheniju bezopasnosti sistem gorjachego vodosnabzhenija. Sanitarno-jepidemiologicheskie pravila i normativy» [SanPin 2.1.4.1074-01 «Drinking water. Hygienic requirements to water quality of centralized drinking water supply systems. Quality control. Hygienic requirements for safety of hot water systems. Sanitary-epidemiological rules and regulations»]. Moscow: Rospotrebnadzor, 2001. 112 p. (In Russan).

4. Mohyla P., Bilgili S. F., Oyarzabal O. A. et al. Application of Acidified Sodium Chlorite in the Drinking Water to Control Salmonella serotype Typhimurium and Campylobacter jejuni in Commercial Broilers. J. Appl. Poult Res., 2007, vol. 16, no. 1, pp. 45-51. doi: 10.1093/japr/16.1.45.

5. Christian M.S., York R.G., Hoberman, A.M. et al. Biodisposition of dibromoacetic acid (DBA) and bromodichloromethane (BDCM) administered to rats and rabbits in drinking water during range-finding reproduction and developmental toxicity studies. International Journal of Toxicology, 2001, vol. 20, pp. 239-253.

6. Hicks S.J., Rowbury R.J. Resistance of attached Escherichia coli to acrylic acid and its significance for the survival of plasmid-bearing organisms in water. Ann. Inst. Pasteur, 1987, vol. 138, pp. 359-369.

7. International Life Sciences Institute. An Evaluation of EPA's Proposed Guidelines for Carcinogen Risk Assessment Using Chloroform and Dichloroacetate as Case Studies. Report of an Expert Panel, ILSI HESI, Washington, DC, November 1997. $240 \mathrm{p}$.

8. Christian M.S., York R.G., Hoberman A.M. et al. Oral (drinking water) developmental toxicity studies of bromodichloromethane (BDCM) in rats and rabbits. International Journal of Toxicology, 2001, vol. 20, pp. $225-237$.

9. Christian M.S., York R.G., Hoberman A.M. et al. Oral (drinking water) two-generation reproductive toxicity study of bromodichloromethane (BDCM) in rats. International Journal of Toxicology, 2002, vol. 21, pp. 115-146.

10. Oyarzabal O.A. Reduction of Campylobacter spp. by commercial antimicrobials applied during the processing of broiler chickens: a review from the United States perspective. J. Food Prot., 2005, vol. 68, pp. 1752-1760.

11. Scientific Opinion of the Panel on Biological Hazards on a request from DG SANCO on the assessment of the possible effect of the four antimicrobial treatment substances on the emergence of antimicrobial resistance. The EFSA Journal, 2008, vol. 659, pp. 1-26.

12. Whiting G.C., Rowbury R.J. Increased resistance of Escherichia coli to acrylic acid and to copper ions after cold-shock. Letts. Appl. Microbiol., 1995, vol. 20, pp. 240-242.

13. Yang, H., Li, Y. Johnson, M.G. Survival and death of Salmonella typhimurium and Campylobacter jejuni in processing water and on chicken skin during poultry scalding and chilling. J. Food Prot., 2001, vol. 64, pp. 770-776. 


\title{
STUDY OF TOLERANCE OF ENTEROBACTERIA TO CHLORINE-BASED BIOCIDES IN EXPERIMENTAL MODELS USING CHROMOGENIC INDICATOR TESTS
}

\author{
N.R. Efimochkina, I.B. Bykova, Yu.V. Korotkevich, Yu.M. Markova, \\ L.P. Minaeva, S.A. Sheveleva
}

FSBI "Institute of Nutrition", Russian Federation, Moscow, 2/14 Ustinsky Passage, 109240

\begin{abstract}
The species-specific composition of microbial contaminants of vegetable raw materials and equipment used in the production of biotechnological products and beverages fermentation are studied. 85 enterobacteria strains was isolated and investigated, 46 strains of the genera Enterobacter, Pantoea, Citrobacter, Serratia, Escherichia, Cronobacter was identified to the species level; the most frequently detected bacteria of the genera Enterobacter and Pantoea (about $50 \%$ ). For the first time developed and tested chromogenic in vitro model based that allows to quantify the degree of inhibition of gram-negative microflora under the influence of antimicrobial agents depending on the concentrations of biocides and density of bacterial populations. A comparative analysis of the tolerance of Enterobacteriaceae strains from different biotopes was conducted. Sensitivity to the treatment of chlorine-containing biocides in 26 strains of enterobacteria from plant material and 9 strains of Escherichia coli from the intestine of male rats of Wistar line was tested. Enterobacteria from vegetable raw materials and swabs were more resistant to antimicrobial action of chlorine, than the representatives of the populations of the normal intestinal microbiota. It is established that the active chlorine concentration of $50-100 \mathrm{mg} / \mathrm{dm}^{3}$, the most commonly used in the processing of vegetable raw materials, is not effective for Enterobacteriaceae, if the density of the microbial population is $10^{5-7}$ cells $/ \mathrm{cm}^{3}$ and above. At an initial level of contamination with Enterobacteriaceae not more than $10^{3} \mathrm{cells} / \mathrm{cm}^{3} \mathrm{proc}$ essing solutions with a concentration of active chlorine of 75 to $100 \mathrm{mg} / \mathrm{dm}^{3}$ can provide effective disinfection of raw materials, equipment, or inventory. Experimental chromogenic in vitro model proposed to assess the impact of chlorine-based biocides on the degree of the enterobacteria inhibition, can be used to justify the selection and doses of antimicrobial agents, effective against other groups of microbial contaminants. This will optimize the use of modes of decontamination of raw materials and sanitizing equipment in the food industry.
\end{abstract}

Key words: enterobacteria, chromogenic model in vitro, vegetable raw materials, chlorine-based biocides, tolerance.

(C) Efimochkina N.R., Bykova I.B., Korotkevich Yu.V., Markova Yu.M., Minaeva L.P., Sheveleva S.A., 2015

Efimochkina Natalia Ramazanovna - Doctor of biological sciences, leading research worker of the Laboratory of biosafety and nutrimicrobiom analysis (e-mail: karlikanova@ion.ru; tel. 8 (495) 698-53-83; 8 (915) 366-62-59).

Bykova Irina Borisovna - research worker of the Laboratory of biosafety and nutrimicrobiom analysis (e-mail: bykova@ion.ru; tel. 8 (495) 698-53-83).

Korotkevich Yulia Vladimirovna - junior research worker of the Laboratory of biosafety and nutrimicrobiom analysis (e-mail: ulya_korotkevich@mail.ru; tel. 8 (495) 698-53-83).

Markova Yulia Mikhailovna - junior research worker of the Laboratory of biosafety and nutrimicrobiom analysis (e-mail: yulia.markova.ion@gmail.com; tel. 8 (495) 698-53-83).

Minaeva Liudmila Pavlovna - Candidate of technical sciences, leading research worker of the Laboratory of biosafety and nutrimicrobiom analysis (e-mail: Liuminaeva-ion@mail.ru; tel. 8 (495) 698-53-83).

Sheveleva Svetlana Anatolievna - Doctor of biological sciences, head of the Laboratory of biosafety and nutrimicrobiom analysis (e-mail: sheveleva@ion.ru; tel. 8 (495) 698-53-83). 


\section{ИНФОРМАЦИЯ О ПОДПИСКЕ НА 2016 г.}

С 1 сентября 2015 г. открыта годовая подписка на все выпуски журнала «Анализ риска здоровью» за 2016 г.

С 1 декабря 2015 г. журнал «Анализ риска здоровью» входит в Перечень рецензируемых научных изданий, в которых должны быть опубликованы основные результаты диссертаций на соискание ученой степени кандидата наук, на соискание ученой степени доктора наук (Перечень ВАК).

Наш подписной индекс по каталогам российской прессы «Почта России»: $\underline{04153}$.

Предлагаем вам оформить подписку на журнал, выбрав любой удобный для вас способ подписки:

- В любом почтовом отделении РФ по действующим каталогам российской прессы «Почта России». Подробную информацию о стоимости (в зависимости от региона доставки) вы можете найти на сайте «Межрегионального агентства подписки», а также подписаться на издание онлайн: http: //vipishi.ru/catalog-Pochta-Russia/item/inet/330/29/04153/analiz-riska-zdorovyu/

Цена подписки за 12 месяцев, например, для региона Москва: 2802.41 руб.

Форма подписки - годовая.

Подписка по данному индексу на январь-декабрь принимается «Межрегиональным агентством подписки» с 1 сентября до 25 декабря 2015 г.!

- Непосредственно в редакции. Заявки с подробными реквизитами вашей организации принимаются по электронной почте: journal@fcrisk.ru. Просьба четко обозначать почтовый адрес, на который будет выслан журнал и все необходимые документы, отделять от юридических и пр. адресов. После вам будет выслан договор, и счет на оплату. Форма оплаты: авансовая (в 100\%-ном размере).

Цена подписки за 12 месяцев для любого региона России: 3000 руб. (с учетом почтовых расходов).

Форма подписки - годовая.

Подписка в редакции начинается после завершения официального подписного периода по каталогам «Почта России». После 10 января 2016 г. вы можете заключить договор на поставку журнала в нашей редакции.

По всем вопросам, связанным с подпиской на журнал, вы можете обратиться по электронной почте journal@fcrisk.ru. 